Prepared in cooperation with the South Carolina Department of Natural Resources

\title{
Groundwater Availability in the Crouch Branch and McQueen Branch Aquifers, Chesterfield County, South Carolina, 1900-2012
}

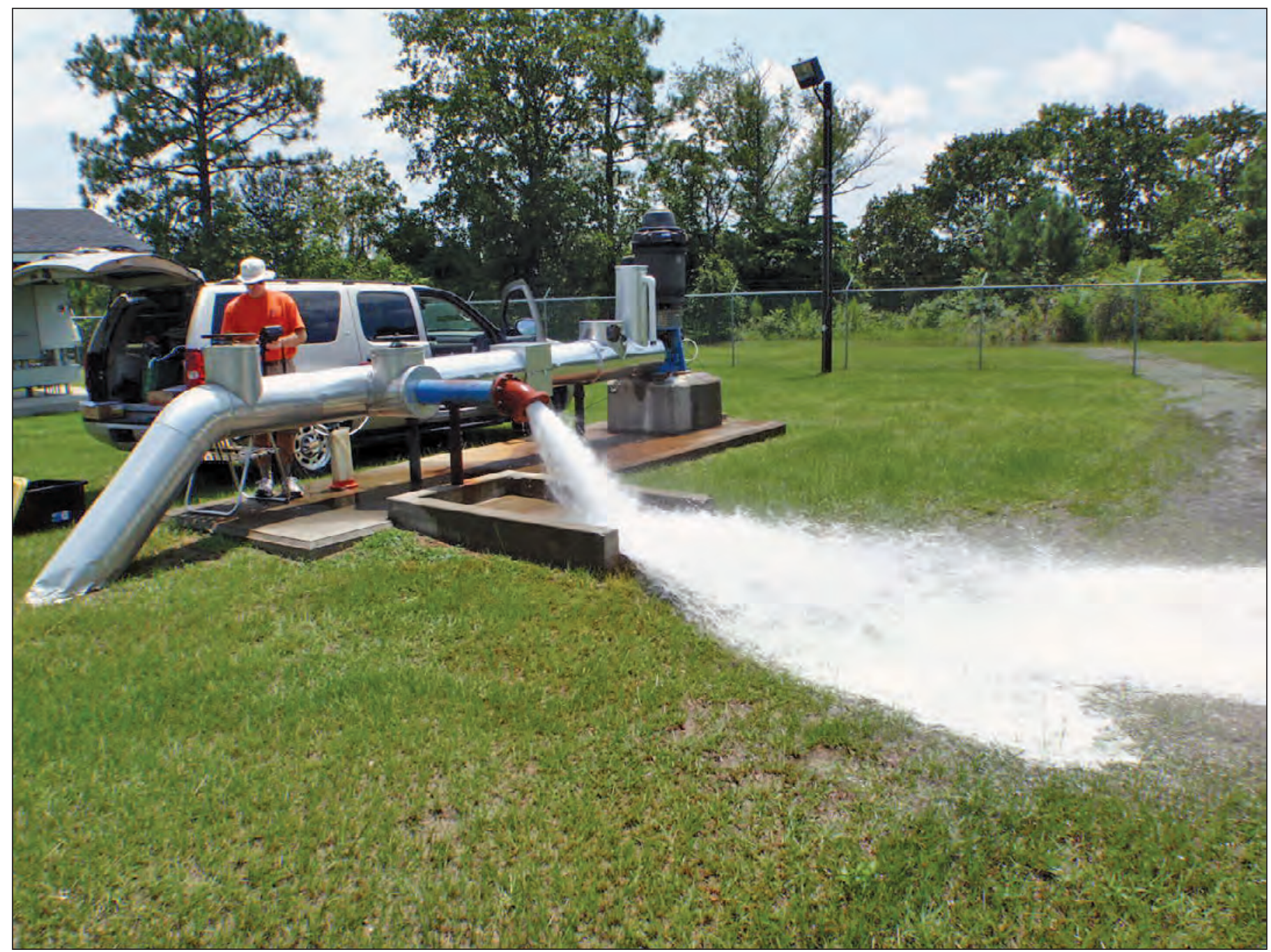

Scientific Investigations Report 2014-5050

U.S. Department of the Interior

U.S. Geological Survey 
Cover. Alligator Rural Water and Sewer Company Public-Supply Well 8 being pumped nearly 1,000 gallons per minute on August 4, 2010 (photograph by Bruce G. Campbell, U.S. Geological Survey). 


\section{Groundwater Availability in the Crouch Branch and McQueen Branch Aquifers, Chesterfield County, South Carolina, 1900-2012}

By Bruce G. Campbell and James E. Landmeyer

Prepared in cooperation with the South Carolina Department of Natural Resources

Scientific Investigations Report 2014-5050 


\title{
U.S. Department of the Interior SALLY JEWELL, Secretary
}

\section{U.S. Geological Survey Suzette M. Kimball, Acting Director}

\author{
U.S. Geological Survey, Reston, Virginia: 2014
}

For more information on the USGS - the Federal source for science about the Earth, its natural and living resources, natural hazards, and the environment, visit http://WWw.usgs.gov or call 1-888-ASK-USGS

For an overview of USGS information products, including maps, imagery, and publications, visit http://WwW.usgs.gov/pubprod

To order this and other USGS information products, visit http://store.usgs.gov

Any use of trade, firm, or product names is for descriptive purposes only and does not imply endorsement by the U.S. Government.

Although this information product, for the most part, is in the public domain, it also may contain copyrighted materials as noted in the text. Permission to reproduce copyrighted items must be secured from the copyright owner.

Suggested citation:

Campbell, B.G., and Landmeyer, J.E., 2014, Groundwater availability in the Crouch Branch and McQueen Branch aquifers, Chesterfield County, South Carolina, 1900-2012: U.S. Geological Survey Scientific Investigations Report 2014-5050, 68 p., http://dx.doi.org/10.3133/sir20145050.

ISSN 2328-0328 (Online) 


\section{Contents}

Abstract
Introduction
Purpose and Scope
Previous Investigations
Description of Study Area
Population
Plimate
Physiography Uses
Geology
Hydrogeology. 


\section{Figures}

1. Map showing study area extent, production wells, Sand Hills State Forest, and Carolina Sandhills National Wildlife Refuge, Chesterfield County, South Carolina ..........3

2. Graph showing groundwater use in Chesterfield County, South Carolina, 1983-2010.....4

3. Map showing precipitation stations and active and inactive streamgages in the Chesterfield County area.

4. Graph showing parameter-elevation regressions on independent slopes model data and National Weather Service precipitation data at Cheraw, South Carolina, from 1900 to 2012

5. Map showing locations of Black Creek and Upper Drowning Creek Basins, North and South Carolina ............................................................................................

6. Map showing major rivers and streams in the Chesterfield County area .........................9

7. Map showing land-surface altitudes of the Chesterfield County area ............................10

8. Map showing land use in the Chesterfield County area ................................................11

9A. Diagram showing hydrogeologic framework of the Chesterfield County area................13

9B. Map showing areal extent and altitude of the top of the McQueen Branch confining unit, Chesterfield County area

9C. Map showing areal extent and altitude of the top of the McQueen Branch aquifer, Chesterfield County area.

10. Map showing locations of production, irrigation, domestic, and monitoring wells used in this study, Chesterfield County area.

11. Map showing locations of groundwater observation wells drilled for the study and wells used for continuous groundwater-level recording, Chesterfield County area .....18

12A. Map showing locations of wells with groundwater-level measurements from the Crouch Branch aquifer used in this study, Chesterfield County area

12B. Map showing locations of wells with groundwater-level measurements from the McQueen Branch aquifer used in this study, Chesterfield County area

13. Map showing locations of streamflow measurement sites, Chesterfield County area..21

14. Map showing Chesterfield County area groundwater-flow model grid with a uniform 300 -foot by 300 -foot model cell size.

15. Graph showing groundwater-flow model stress periods, 1900 to 2012,

Chesterfield County area

16. Conceptual model of the aquifers and confining units of the Atlantic Coastal Plain in the Chesterfield County area

17. Graph showing simulated net recharge rates (1900-2012) for the wetlands and uplands areas, Chesterfield County area

18. Map showing National Wetlands Inventory areas within the Chesterfield County area.

19. Map showing locations of Black Creek Basin streamgages and locations of selected streamflow measurement sites on Swift Creek, Big Sandy Creek, and Little Rocky Creek in the Chesterfield County area.

20. Map showing calibrated horizontal hydraulic conductivities for the Crouch Branch aquifer in the Chesterfield County area

21. Map showing calibrated horizontal hydraulic conductivities for the McQueen Branch aquifer in the Chesterfield County area

22. Map showing calibrated horizontal hydraulic conductivities for the McQueen Branch confining unit in the Chesterfield County area 
23. Graph showing observed and simulated groundwater levels (1940-2012) for

the Crouch Branch aquifer in the Chesterfield County area .....

24. Graph showing water-level residuals and simulated water levels (1940-2012)

for the Crouch Branch aquifer in the Chesterfield County area

25. Map showing simulated water levels and water-level residuals for the Crouch Branch aquifer (2012) in the Chesterfield County area

26. Graph showing observed and simulated groundwater levels (1940-2012) for the McQueen Branch aquifer in the Chesterfield County area

27. Graph showing water-level residuals and simulated water levels (1940-2012) for the McQueen Branch aquifer in the Chesterfield County area .

28. Map showing simulated potentiometric surface of the McQueen Branch aquifer (2012) in the Chesterfield County area.

29. Hydrographs of simulated and observed water levels for the Crouch Branch aquifer in the Chesterfield County area

30. Hydrographs of simulated and observed water levels for the McQueen Branch aquifer in the Chesterfield County area.

31. Hydrographs of simulated and observed base flows in Black Creek at three gaging stations in the Chesterfield County area: Black Creek below Chesterfield (02130840), Black Creek near McBee (02130900), and Black Creek near Hartsville (02130910) ........42

32. Hydrographs of simulated and observed base flows at Cedar Creek near Society Hill, South Carolina (02130600) and Juniper Creek near Cheraw, South Carolina (02130500)

33. Graphs showing sensitivity rankings for drain conductances, horizontal anisotropy parameters for the Crouch Branch aquifer, and horizontal anisotropy parameters for the McQueen Branch aquifer in the Chesterfield County area.....

34. Graphs showing sensitivity rankings for horizontal hydraulic conductivity pilot point parameters for the Crouch Branch aquifer, the McQueen Branch confining unit, and the McQueen Branch aquifer in the Chesterfield County area.

35. Graphs showing sensitivity rankings for recharge fluxes on uplands and wetlands areas in the Chesterfield County area

36. Graph showing simulated water budget per stress period in the Atlantic Coastal Plain from predevelopment (1900) to 2012 in the Chesterfield County area

37. Diagram showing water budgets for wet (1998) and dry (2012) years for the Chesterfield County area.....

38. Map showing water budget areas for the Alligator Rural Water and Sewer Company well field near McBee, South Carolina, and the Carolina Sandhills National Wildlife Refuge acquisition area, Chesterfield County .

39. Diagram showing water budget for wet (1998) and dry (2012) years for the McBee, South Carolina, area

40. Diagram showing water budget for wet (1998) and dry (2012) years for the Carolina Sandhills National Wildlife Refuge acquisition area, Chesterfield County, South Carolina

41. Map showing selected streams for water-budget analysis in the McBee, South Carolina, area

1-1. Map showing altitude of the top of the crystalline basement rocks underlying the Atlantic Coastal Plain in the McBee, South Carolina, area as interpreted from horizontal-to-vertical spectral-ratio measurements and geologic borings.

1-2. Map showing thickness of the Atlantic Coastal Plain sediments in the McBee, South Carolina, area as interpreted from horizontal-to-vertical spectral-ratio measurements and geologic borings 


\section{Tables}

1. Streamflow measurement sites in the Chesterfield County area...................................22

2. Summary statistics for the calibrated horizontal hydraulic conductivities in the Chesterfield County area.

3. Statistics for model calibration for the Chesterfield County area..

4. Simulated 2012 base flows for McBee, South Carolina, area streams within the Alligator Rural Water and Sewer well field under conditions of pumping and no pumping.

1-1. Locations and altitudes of bedrock surfaces for geologic borings where bedrock was encountered during drilling in the McBee, South Carolina, area .

1-2. Horizontal-to-vertical spectral-ratio measurement locations, estimated bedrock altitude, land-surface altitude, and estimated sediment thickness of the Atlantic Coastal Plain sediments in the vicinity of McBee, South Carolina.

\section{Acknowledgments}

The authors would like to acknowledge assistance provided by the following: Alligator Rural Water and Sewer Company, South Carolina Department of Health and Environmental Control, McCleod Farms, Inc., Carolina Sandhills National Wildlife Refuge, Sand Hills State Forest, Mr. William F. Pritchard, Nestlé Waters, Inc., Darlington County Water and Sewer, Cheraw State Fish Hatchery, and many domestic-well owners who allowed access to their wells.

Brian Clark (U.S. Geological Survey Arkansas Water Science Center) and Connor Haugh (U.S. Geological Survey Tennessee Water Science Center) provided colleague reviews of this report. Larry Harrelson (U.S. Geological Survey-retired) was integral to the early part of the study, collecting groundwater data and helping conceptualize the groundwater-flow system. 


\section{Conversion Factors and Datums}

Inch/Pound to SI

\begin{tabular}{|c|c|c|}
\hline Multiply & By & To obtain \\
\hline \multicolumn{3}{|c|}{ Length } \\
\hline inch & 2.54 & centimeter $(\mathrm{cm})$ \\
\hline inch & 25.4 & millimeter (mm) \\
\hline foot $(\mathrm{ft})$ & 0.3048 & meter $(\mathrm{m})$ \\
\hline mile (mi) & 1.609 & kilometer (km) \\
\hline \multicolumn{3}{|c|}{ Area } \\
\hline acre & 4,047 & square meter $\left(\mathrm{m}^{2}\right)$ \\
\hline acre & 0.004047 & square kilometer $\left(\mathrm{km}^{2}\right)$ \\
\hline square foot $\left(\mathrm{ft}^{2}\right)$ & 929.0 & square centimeter $\left(\mathrm{cm}^{2}\right)$ \\
\hline square foot $\left(\mathrm{ft}^{2}\right)$ & 0.09290 & square meter $\left(\mathrm{m}^{2}\right)$ \\
\hline square mile $\left(\mathrm{mi}^{2}\right)$ & 2.59 & square kilometer $\left(\mathrm{km}^{2}\right)$ \\
\hline \multicolumn{3}{|c|}{ Volume } \\
\hline million gallons (Mgal) & 3,785 & cubic meter $\left(\mathrm{m}^{3}\right)$ \\
\hline cubic foot $\left(\mathrm{ft}^{3}\right)$ & 0.02832 & cubic meter $\left(\mathrm{m}^{3}\right)$ \\
\hline \multicolumn{3}{|c|}{ Flow rate } \\
\hline inch per year (in/yr) & 25.4 & millimeter per year (mm/yr) \\
\hline foot per day (ft/d) & 0.3048 & meter per day $(\mathrm{m} / \mathrm{d})$ \\
\hline foot per year (ft/yr) & 0.3048 & meter per year (m/yr) \\
\hline cubic foot per second $\left(\mathrm{ft}^{3} / \mathrm{s}\right)$ & 0.02832 & cubic meter per second $\left(\mathrm{m}^{3} / \mathrm{s}\right)$ \\
\hline cubic foot per day $\left(\mathrm{ft}^{3} / \mathrm{d}\right)$ & 0.02832 & cubic meter per day $\left(\mathrm{m}^{3} / \mathrm{d}\right)$ \\
\hline gallon per day (gal/d) & 0.003785 & cubic meter per day $\left(\mathrm{m}^{3} / \mathrm{d}\right)$ \\
\hline million gallons per day $(\mathrm{Mgal} / \mathrm{d})$ & 0.04381 & cubic meter per second $\left(\mathrm{m}^{3} / \mathrm{s}\right)$ \\
\hline \multicolumn{3}{|c|}{ Hydraulic conductivity } \\
\hline foot per day (ft/d) & 0.3048 & meter per day $(\mathrm{m} / \mathrm{d})$ \\
\hline \multicolumn{3}{|c|}{ Hydraulic gradient } \\
\hline foot per mile ( $\mathrm{ft} / \mathrm{mi})$ & 0.1894 & meter per kilometer $(\mathrm{m} / \mathrm{km})$ \\
\hline \multicolumn{3}{|c|}{ Transmissivity* } \\
\hline foot squared per day $\left(\mathrm{ft}^{2} / \mathrm{d}\right)$ & 0.09290 & meter squared per day $\left(\mathrm{m}^{2} / \mathrm{d}\right)$ \\
\hline
\end{tabular}

Temperature in degrees Celsius $\left({ }^{\circ} \mathrm{C}\right)$ may be converted to degrees Fahrenheit $\left({ }^{\circ} \mathrm{F}\right)$ as follows:

$$
{ }^{\circ} \mathrm{F}=\left(1.8 \times{ }^{\circ} \mathrm{C}\right)+32
$$

Temperature in degrees Fahrenheit ( $\left.{ }^{\circ} \mathrm{F}\right)$ may be converted to degrees Celsius $\left({ }^{\circ} \mathrm{C}\right)$ as follows:

$$
{ }^{\circ} \mathrm{C}=\left({ }^{\circ} \mathrm{F}-32\right) / 1.8
$$

Vertical coordinate information is referenced to the North American Vertical Datum of 1988 (NAVD 88).

Horizontal coordinate information is referenced to the North American Datum of 1983 (NAD 83).

Altitude, as used in this report, refers to distance above the vertical datum.

*Transmissivity: The standard unit for transmissivity is cubic foot per day per square foot times foot of aquifer thickness $\left[\left(\mathrm{ft}^{3} / \mathrm{d}\right) / \mathrm{ft}^{2}\right] \mathrm{ft}$. In this report, the mathematically reduced form, foot squared per day $\left(\mathrm{ft}^{2} / \mathrm{d}\right)$, is used for convenience. 


\section{Acronyms and Abbreviations}

$\begin{array}{ll}\text { ACP } & \text { Atlantic Coastal Plain } \\ \text { ARWS } & \text { Alligator Rural Water and Sewer Company } \\ \text { CSNWR } & \text { Carolina Sandhills National Wildlife Refuge } \\ \text { DEM } & \text { Digital Elevation Model } \\ \text { ET } & \text { Evapotranspiration } \\ \text { HYSEP } & \text { Hydrograph Separation Program } \\ \text { HVSR } & \text { Horizontal-to-Vertical Spectral Ratio } \\ \text { MNW } & \text { Multi-Node Well package } \\ \text { MODFLOW } & \text { Modular Three-Dimensional Finite-Difference Groundwater Model } \\ \text { NHD } & \text { National Hydrologic Dataset } \\ \text { NWIS } & \text { National Water Information System } \\ \text { NWS } & \text { National Weather Service } \\ \text { PART } & \text { Hydrograph Separation Program } \\ \text { PEST } & \text { Parameter Estimation Software } \\ \text { PRISM } & \text { Parameter Elevation Regression in Independent Slopes } \\ \text { SSF } & \text { Sand Hills State Forest } \\ \text { SC } & \text { South Carolina } \\ \text { SCDNR } & \text { South Carolina Department of Natural Resources } \\ \text { SCDHEC } & \text { South Carolina Department of Health and Environmental Control } \\ \text { USGS } & \text { U.S. Geological Survey } \\ \text { WEL } & \text { Well Package }\end{array}$




\title{
Groundwater Availability in the Crouch Branch and McQueen Branch Aquifers, Chesterfield County, South Carolina, 1900-2012
}

\author{
By Bruce G. Campbell and James E. Landmeyer
}

\begin{abstract}
Chesterfield County is located in the northeastern part of South Carolina along the southern border of North Carolina and is primarily underlain by unconsolidated sediments of Late Cretaceous age and younger of the Atlantic Coastal Plain. Approximately 20 percent of Chesterfield County is in the Piedmont Physiographic Province, and this area of the county is not included in this study. These Atlantic Coastal Plain sediments compose two productive aquifers: the Crouch Branch aquifer that is present at land surface across most of the county and the deeper, semi-confined McQueen Branch aquifer. Most of the potable water supplied to residents of Chesterfield County is produced from the Crouch Branch and McQueen Branch aquifers by a well field located near McBee, South Carolina, in the southwestern part of the county. Overall, groundwater availability is good to very good in most of Chesterfield County, especially the area around and to the south of McBee, South Carolina. The eastern part of Chesterfield County does not have as abundant groundwater resources, but resources are generally adequate for domestic purposes.

The primary purpose of this study was to determine groundwater-flow rates, flow directions, and changes in water budgets over time for the Crouch Branch and McQueen Branch aquifers in the Chesterfield County area. This goal was accomplished by using the U.S. Geological Survey finite-difference MODFLOW groundwater-flow code to construct and calibrate a groundwater-flow model of the Atlantic Coastal Plain of Chesterfield County. The model was created with a uniform grid size of 300 by 300 feet to facilitate a more accurate simulation of groundwater-surface-water interactions. The model consists of 617 rows from north to south extending about 35 miles and 884 columns from west to east extending about 50 miles, yielding a total area of about 1,750 square miles. However, the active part of the modeled area, or the part where groundwater flow is simulated, totaled about 1,117 square miles.
\end{abstract}

Major types of data used as input to the model included groundwater levels, groundwater-use data, and hydrostratigraphic data, along with estimates and measurements of stream base flows made specifically for this study. The groundwaterflow model was calibrated to groundwater-level and stream base-flow conditions from 1900 to 2012 using 39 stress periods. The model was calibrated with an automated parameter-estimation approach using the computer program PEST, and the model used regularized inversion and pilot points. The groundwater-flow model was calibrated using field data that included groundwater levels that had been collected between 1940 and 2012 from 239 wells and base-flow measurements from 44 locations distributed within the study area. To better understand recharge and inter-aquifer interactions, seven wells were equipped with continuous groundwater-level recording equipment during the course of the study, between 2008 and 2012. These water levels were included in the model calibration process. The observed groundwater levels were compared to the simulated ones, and acceptable calibration fits were achieved. Root mean square error for the simulated groundwater levels compared to all observed groundwater levels was 9.3 feet for the Crouch Branch aquifer and 8.6 feet for the McQueen Branch aquifer.

The calibrated groundwater-flow model was then used to calculate groundwater budgets for the entire study area and for two sub-areas. The sub-areas are the Alligator Rural Water and Sewer Company well field near McBee, South Carolina, and the Carolina Sandhills National Wildlife Refuge acquisition boundary area. For the overall model area, recharge rates vary from 56 to 1,679 million gallons per day (Mgal/d) with a mean of $737 \mathrm{Mgal} / \mathrm{d}$ over the simulation period (1900-2012). The simulated water budget for the streams and rivers varies from 653 to $1,127 \mathrm{Mgal} / \mathrm{d}$ with a mean of $944 \mathrm{Mgal} / \mathrm{d}$. The simulated "storage-in term" ranges from 0 to $565 \mathrm{Mgal} / \mathrm{d}$ with a mean of $276 \mathrm{Mgal} / \mathrm{d}$. The simulated "storage-out term" has a range of 0 to $552 \mathrm{Mgal} / \mathrm{d}$ with a mean of $77 \mathrm{Mgal} / \mathrm{d}$. Groundwater budgets for the McBee, South Carolina, area and the Carolina Sandhills National Wildlife Refuge acquisition area had similar results. 


\section{Groundwater Availability in the Crouch Branch and McQueen Branch Aquifers, Chesterfield County, South Carolina, 1900-2012}

An analysis of the effects of past and current groundwater withdrawals on base flows in the McBee area indicated a negligible effect of pumping from the Alligator Rural Water and Sewer well field on local stream base flows. Simulated base flows for 2012 for selected streams in and around the McBee area were similar with and without simulated groundwater withdrawals from the well field. Removing all pumping from the model for the entire simulation period (1900-2012) produces a negligible difference in increased base flow for the selected streams. The 2012 flow for Lower Alligator Creek was $5.04 \mathrm{Mgal} / \mathrm{d}$ with the wells pumping and $5.08 \mathrm{Mgal} / \mathrm{d}$ without the wells pumping; this represents the largest difference in simulated flows for the six streams.

\section{Introduction}

Chesterfield County (809 square miles $\left[\mathrm{mi}^{2}\right]$ ) and the surrounding region is a primarily rural area in the northern part of South Carolina (S.C.; fig. 1). Between 2000 and 2010, the population of Chesterfield County increased about 9 percent from 42,768 to 46,734 people (U.S. Census Bureau, 2013). This population increase, as well as potential economic development in the area, is associated with increased demand for high-quality drinking or process water in Chesterfield County. As residential, agricultural, industrial, and other forms of projected development occur, increased demands for groundwater will put further pressure on the water resources of the region. Natural pressures such as periodic severe droughts have placed additional stresses on the water resources of the area (Gellici and others, 2004).

Currently (2013), the principal sources of potable water supply for most of Chesterfield County are the Crouch Branch and McQueen Branch aquifers, which generally contain highquality groundwater. In 2010, the total groundwater use reported for Chesterfield County by the South Carolina Department of Health and Environmental Control (SCDHEC) was 4.62 million gallons per day (Mgal/d) (South Carolina Department of Health and Environmental Control, 2002, 2006; Alex Butler, South Carolina Department of Health and Environmental Control, written commun., 2010). This groundwater use is primarily derived from a well field near McBee, S.C. (fig. 1), operated by Alligator Rural Water and Sewer Company (ARWS), and supplies most of the potable water for the county, with the exception of Cheraw, S.C. (which is supplied by surface-water withdrawals from the Pee Dee River). Groundwater use in Chesterfield County has increased substantially since 1983 (when groundwater-use data became available) when about $0.1 \mathrm{Mgal} / \mathrm{d}$ was reportedly used for all purposes (public supply, industrial, irrigation, and mine dewatering) (fig. 2). As pipelines were completed to the towns in the northwestern part of Chesterfield County (fig. 1), there was an increase in groundwater withdrawals beginning about 2001 (fig. 2). In addition to reported water use, an unknown volume of groundwater is withdrawn in the study area for domestic, irrigation, industrial, and other uses. This unreported groundwater use falls outside of the SCDHEC regulatory reporting requirement of 3 million gallons in any month of the year (South Carolina Department of Health and Environmental Control, 2006). Chesterfield County has surface-water resources available; however, these surface-water sources, with the exception of the Pee Dee River, tend to be difficult to treat to drinking water standards and are susceptible to low flows during drought periods.

As demand increases, groundwater withdrawals from the aquifers underlying the study area may overstress the groundwater resources and possibly lower groundwater levels. Lower groundwater levels could potentially reduce base flow to streams and rivers in the area and affect groundwater levels in adjacent areas. In addition, Chesterfield County is home to a major State forest (Sand Hills State Forest; SSF) and an extensive Federal wildlife refuge (Carolina Sandhills National Wildlife Refuge; CSNWR). The CSNWR and the SSF are located in central and southern Chesterfield County, respectively, near the ARWS well field near McBee, S.C. (fig. 1). This area contains more than 95,000 acres of critical longleaf pine habitat and contains a large population of endangered red-cockaded woodpeckers (U.S. Fish and Wildlife Service, 2007). A reduction in groundwater levels or groundwater base flows to surface-water bodies could have a negative effect on these protected natural resources.

To address the concerns of public, private, and governmental users of the groundwater resources in Chesterfield County, the U.S. Geological Survey (USGS), in cooperation with the South Carolina Department of Natural Resources (SCDNR), compiled and interpreted hydrologic data and constructed and calibrated a groundwater-flow model for the county. Model simulations are used in this study to provide information to facilitate the best management of the groundwater resources in Chesterfield County. This study also addresses one of the six USGS science strategy goals, "Quantifying, forecasting, and securing freshwater for America's future" (U.S. Geological Survey, 2007). 


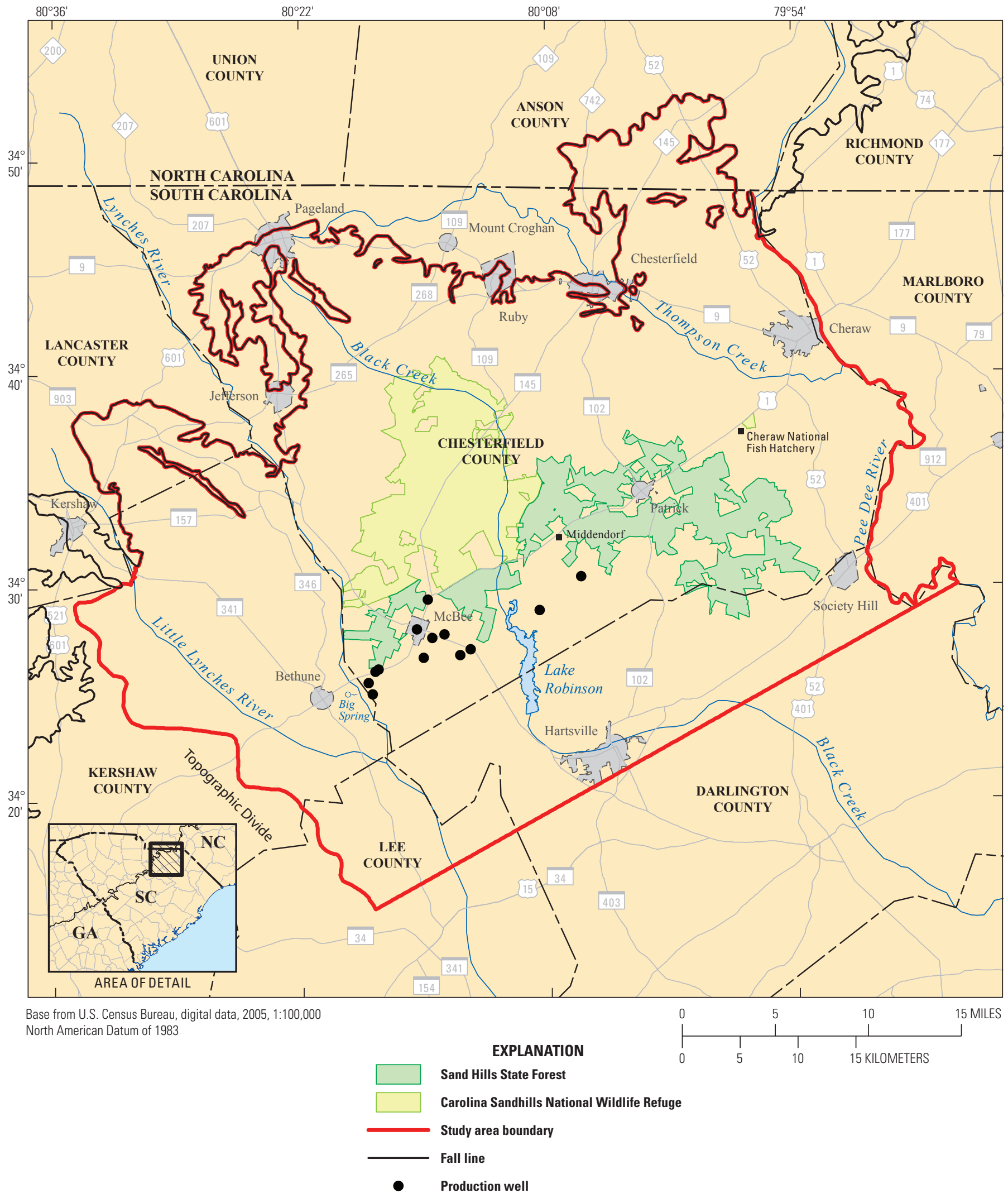

Figure 1. Study area extent, production wells, Sand Hills State Forest, and Carolina Sandhills National Wildlife Refuge, Chesterfield County, South Carolina. 


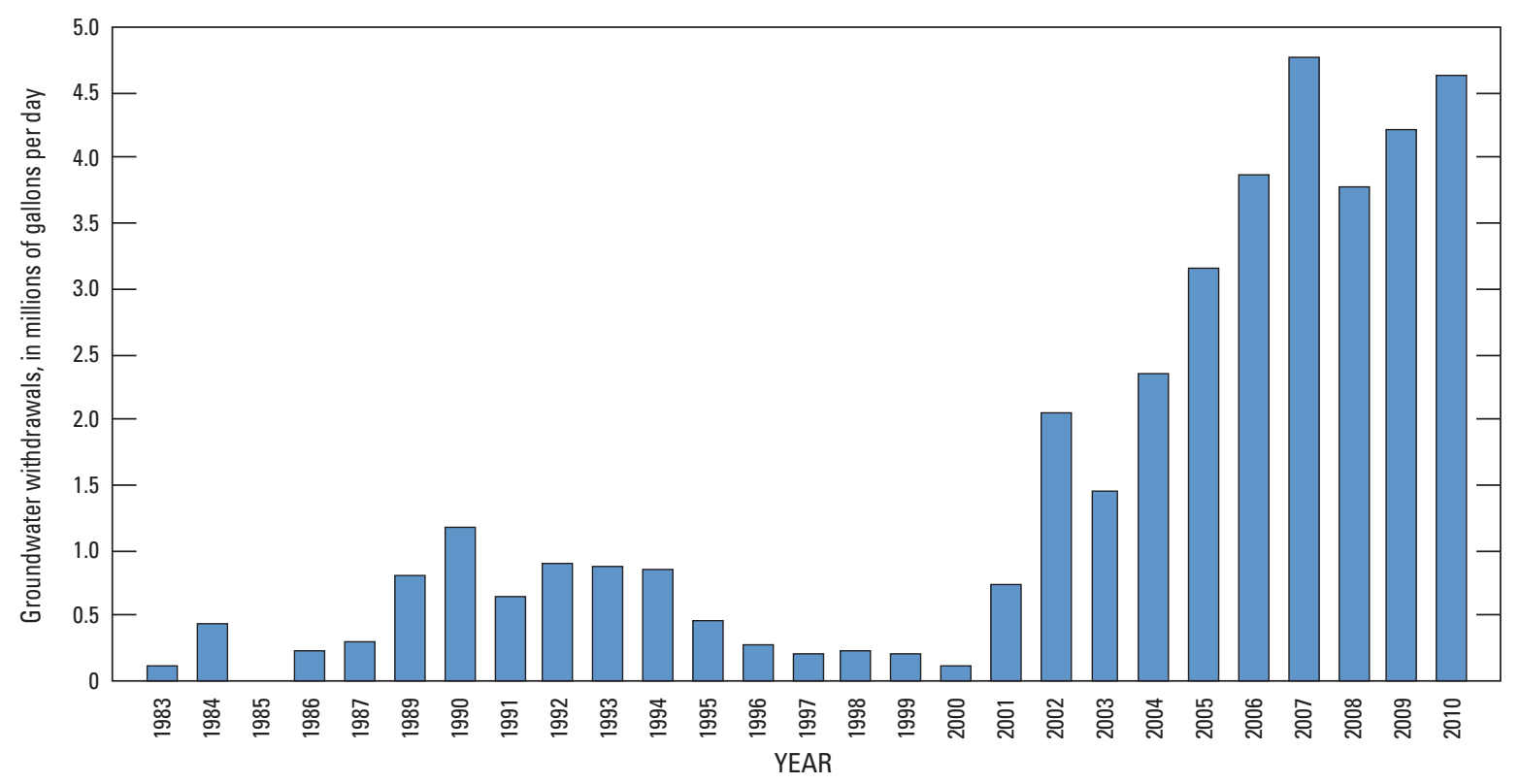

Figure 2. Groundwater use in Chesterfield County, South Carolina, 1983-2010 (source: South Carolina Department of Health and Environmental Control, 2002, 2006; Alex Butler, South Carolina Department of Health and Environmental Control, written commun., 2010).

\section{Purpose and Scope}

The primary purpose of this investigation was to evaluate long-term concerns regarding groundwater availability from the Atlantic Coastal Plain aquifers in the Chesterfield County study area. This report documents the development, calibration, and analysis of a finite difference, numerical groundwater-flow model of the Atlantic Coastal Plain sediments underlying the Chesterfield County, S.C., area. As part of the study, the groundwater-flow model was used to determine groundwaterflow rates, flow directions, and changes in water budgets over time. Groundwater budgets for the entire study area, along with subareas centered on McBee and the CSNWR, were simulated. Base-flow budgets for six small streams in the vicinity of the ARWS well field are analyzed to determine if pumping from the McBee area has negatively affected base flows.

Groundwater-flow models are commonly used analytical tools for quantifying groundwater flow and budgets. Modeling results also can be used to evaluate future stresses given likely management scenarios and the design of monitoring networks that address specific long-term questions. In this case, study objectives were met by developing a numerical groundwaterflow model of the aquifers and confining unit of the groundwater-flow system using the USGS modular finite-difference groundwater-flow model, MODFLOW-2000 (Harbaugh and others, 2000). The Chesterfield County groundwater-flow model represents transient three-dimensional groundwater flow from 1900 to 2012.
The groundwater-flow model includes the Crouch Branch aquifer, the McQueen Branch confining unit, and the McQueen Branch aquifer underlying Chesterfield County and parts of Darlington, Lee, Lancaster, and Kershaw Counties in South Carolina and a small part of Anson County in North Carolina (fig. 1). The modeling effort is limited to the unconsolidated sediments of Upper Cretaceous and younger age of the upper Atlantic Coastal Plain Physiographic Province beneath the model area. The up-dip and basal limits of this modeling effort are the crystalline bedrock of the Piedmont Physiographic Province. The crystalline bedrock typically yields much less groundwater to wells than the Atlantic Coastal Plain sediments of Late Cretaceous age and younger and is not included in the scope of this investigation.

\section{Previous Investigations}

The Chesterfield County area has a history of geologic and hydrologic investigations dating back to 1908. A chapter devoted to the discussion of the geology and mineral resources of the State was included in the Handbook of South Carolina in 1908 (Sloan, 1908) and gives a description of the geology of the State, including Chesterfield County. Berry (1914) described plant fossils from the Upper Cretaceous sediments near Middendorf, Chesterfield County. Cooke (1936) comprehensively describes and illustrates the geology of the Atlantic Coastal Plain of South Carolina. The geology of the Piedmont 
crystalline and Atlantic Coastal Plain sedimentary rocks near Pageland, S.C., are described in detail and illustrated on an accompanying geologic map by Bell and others (1974). A preliminary geologic map of Chesterfield County by Butler and Howell (1977) illustrates the surficial geology found in Chesterfield County, though not comprehensively. The configuration of the pre-Cretaceous rock surface underlying the Southeastern (Atlantic) Coastal Plain aquifer system, as well as the hydrology of the crystalline rocks, is presented in Wait and Davis (1986). The lithologic description of two cores and groundwater-quality data in the northeastern part of the Atlantic Coastal Plain of South Carolina is presented in Falls (1994). Prowell and others (2003) discuss the chrono- and lithostratigraphic importance of the type section of the Middendorf Formation located near Middendorf, Chesterfield County.

The groundwater resources of Kershaw, Lee, and Chesterfield Counties have been described in reports by Newcome $(2002,2004 a, b)$. These reports present data on the water quality, geology, hydrology, hydraulics, and potential well yields for the aquifers underlying each of the aforementioned counties. The groundwater resources of Darlington County are included in a five-county groundwater modeling report by Rodriguez and others (1994). The report describes the effects of continuous groundwater withdrawals in a five-county study area as well as the results of computer-based simulations to determine the best groundwater management alternatives for selected sites within the five-county study area.

Aucott and Newcome (1986) and Newcome (1993, 2000) published reports that include selected information on well hydraulics and aquifer properties for sites in Chesterfield County. Other reports that include various information on the hydrology in the study area include Aucott and others (1984, 1987a, b), Aucott and Speiran (1985a, b, c, 1986, 1996), and Aucott (1988, 1996). Harrelson and Fine (2006) published a report that represents a partial inventory of wells in North and South Carolina, including several wells within Chesterfield County. Reports by Hockensmith (2003, 2008, and 2012) present the hydrogeology and configuration of the potentiometric surface of the Middendorf aquifer (equivalent to the Crouch Branch and McQueen Branch aquifers described in this report) in the southeastern part of the study area. Discussions about selected springs in South Carolina, some of which are in Chesterfield County, are presented in Mitchell (2004). Reports by Bloxham (1976 and 1979) and Barker (1986) list surface-water base-flow measurements for selected streams in the study area. Computations of groundwater discharge from regional aquifers to large streams (base flow) in the upper Atlantic Coastal Plain of South Carolina are presented in Aucott and others (1987b). Additionally, the characteristics of natural streams during low-flow conditions in the Blue Ridge, Piedmont, and upper Atlantic Coastal Plain Physiographic Provinces of South Carolina are presented in Zalants (1991).

\section{Description of Study Area}

The Chesterfield County study area comprises the Atlantic Coastal Plain part of Chesterfield County and small parts of Darlington, Lee, Lancaster, and Kershaw Counties in northeastern South Carolina and Anson County in North Carolina, occupying approximately $1,117 \mathrm{mi}^{2}$ (fig. 1). The study area includes parts of the Atlantic Coastal Plain sediments and is bounded by the Fall Line to the northwest, the Pee Dee River to the northeast, the northern parts of Lee and Darlington Counties to the southeast, and the topographic divide between the Little Lynches River Basin and the Wateree River Basin in Kershaw County to the southwest. Because of the abundant, white, highly leached sand that covers the land surface of most of the region, this area is informally known as the Sand Hills (Cooke, 1936).

\section{Population}

The population of Chesterfield County in 2010 was 46,748 (U.S. Census Bureau, 2013). The study area includes the following communities (2010 populations): McBee (867), Patrick (351), Cheraw (5,851), Chesterfield (1,427), Ruby (360), Pageland (2,760), and Jefferson (753) (fig. 1). Mount Croghan (195) is just outside the study area; however, all of the town's potable water is supplied by the well field near McBee, S.C. The communities of Society Hill (563) and Hartsville $(7,764)$ in Darlington County and Bethune (334) in Kershaw County also are included in the study area.

\section{Climate}

The relatively low latitudinal location of Chesterfield County along with a strong moderating influence from warm Gulf Stream water along the coast of South Carolina results in an overall mild climate. Also important to the climate are the Blue Ridge Mountains to the north and west, which help to block or delay the movement of cold air masses from the northwest. Abnormal weather patterns can alter or restrict precipitation, resulting in prolonged dry spells (Wachob and others, 2009). Warm summers and mild winters, with mild spring and fall seasons, characterize the climate of the study area. Daytime temperatures (in degrees Fahrenheit) usually are in the 80s and 90s in the summer, and the 40s and 50s in the winter. Temperatures during the year average 60 degrees Fahrenheit $\left({ }^{\circ} \mathrm{F}\right)$; they seldom reach $100^{\circ} \mathrm{F}$ or fall below $10^{\circ} \mathrm{F}$. July is the warmest month, and January is the coolest (Newcome, 2004b).

Precipitation has been recorded at five sites within Chesterfield County. The station with the longest period of record (1893-current) is located in the vicinity of Cheraw, S.C. (fig. 3), is maintained by the National Weather Service (NWS), 


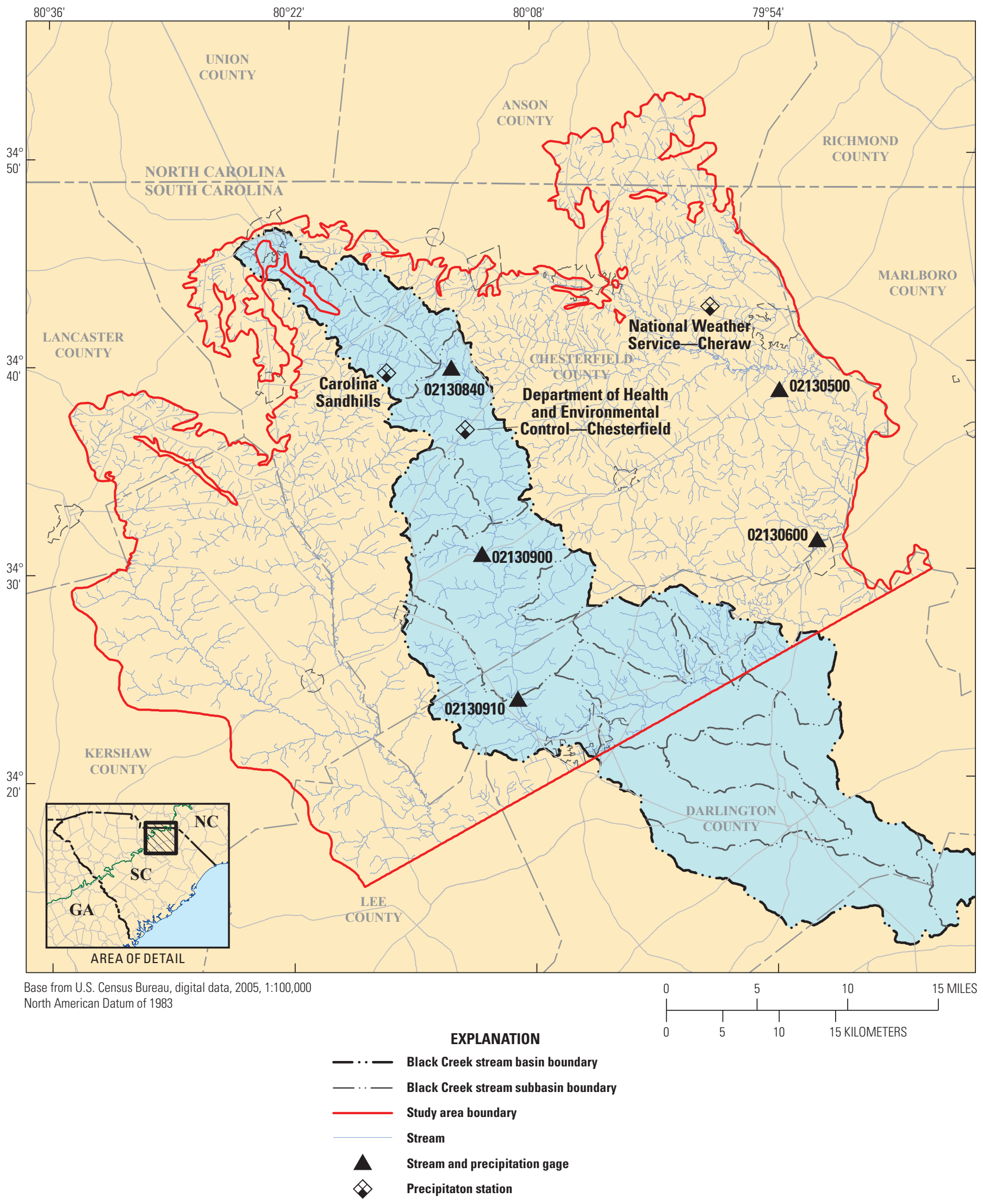

Figure 3. Precipitation stations and active and inactive streamgages in the Chesterfield County area. 
and reports a long-term, annual mean of about 47 inches of precipitation. The lowest recorded value, 29.72 inches, was in 2001, and the highest value, 67.93 inches, was recorded in 1929 (National Oceanic and Atmospheric Administration, 2012). The USGS operates three precipitation gages in the Black Creek Basin that are characterized by short records, the oldest beginning in 1999. Two precipitation gages are located in the CSNWR - one operated by the U.S. Fish and Wildlife Service and another operated by the SCDHEC that have short records of less than 10 years. Parameter-Elevation Regression on Independent Slopes Model (PRISM) (Di Luzio and others, 2008) precipitation data for the entire study area from 1900 to 2012 were obtained and compared to the NWS precipitation data collected at Cheraw, S.C. (fig. 4). Di Luzio and others (2008) describe the PRISM method as "long-range and widearea daily precipitation and temperature data that combines the interpolation of daily ratios/fractions derived from groundbased meteorological station records and respective fields of monthly estimates." The two precipitation datasets correlate fairly closely with an $\mathrm{R}^{2}$ (coefficient of determination; indicates how well data points fit a line or curve) of 0.76 (an $\mathrm{R}^{2}$ of 1.0 indicates the regression line perfectly fits the data) when regressing the annual precipitation totals from 1900 to 2012. Most of the two precipitation records agree relatively closely over time with the exception of 1945 and 2010 to 2012 when the PRISM data are 5-8 inches less than the NWS
Cheraw data and 5 to 8 inches greater in 1908 and 1988. The precipitation data include occasional snowfalls.

The factors of climate and precipitation described above are affected by the processes of evaporation and transpiration. When combined and referred to as evapotranspiration (ET), it is the sum of evaporation of water to the air from sources such as the soil, canopy interception, and water bodiesand the loss of water through plant stomata and, to a lesser extent, bark (Thornthwaite, 1948). Evapotranspiration varies seasonally and can be responsible for removing up to 70 percent of the precipitation in a basin (Thornthwaite, 1948). During times of reduced precipitation, ET continues to deplete water supplies in surfacewater bodies, streams, and sediment and varies according to weather and wind conditions (Hanson, 1991). For the period 1948 to 1990, the annual mean ET for the Chesterfield County region was 30 inches per year (in/yr), and the annual mean water yield (precipitation minus evapotranspiration) ranged from 10 to $15 \mathrm{in} / \mathrm{yr}$ (Cherry and others, 2001). Sanford and Selnick (2012) use a water-balance method combined with a climate and land-cover regression equation to estimate long-term (1971-2000) ET rates for the entire United States. This methodology yields an annual ET rate in the Chesterfield County area that ranges from 27.5 to $31.4 \mathrm{in} / \mathrm{yr}$. Lu and others (2005) provide an ET estimate of 36 in/yr for Upper Drowning Creek Basin in North Carolina (fig. 5), which is hydrologically similar to the Black Creek Basin in Chesterfield County.

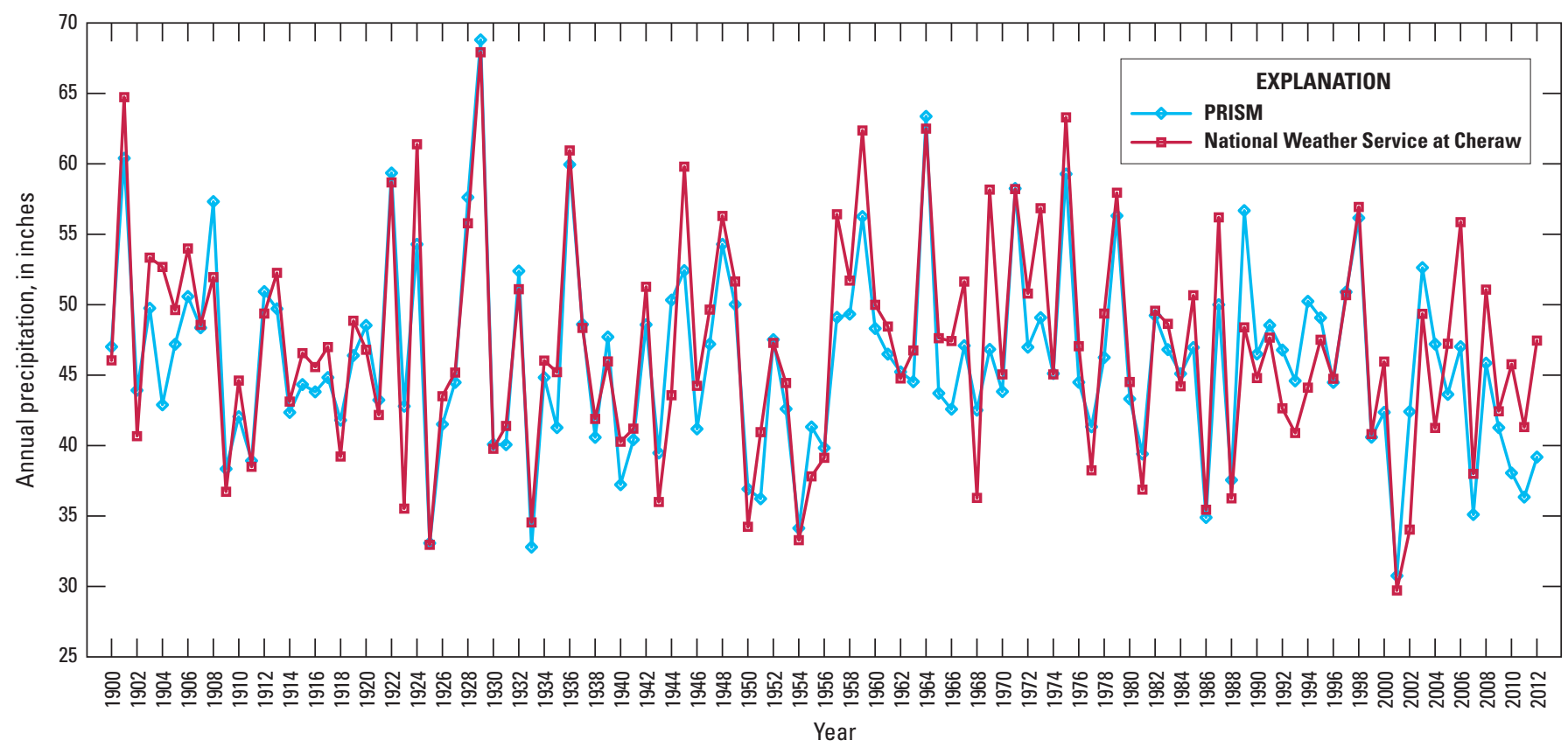

Figure 4. Parameter-elevation regressions on independent slopes model (PRISM) data and National Weather Service precipitation data at Cheraw, South Carolina, from 1900 to 2012. 


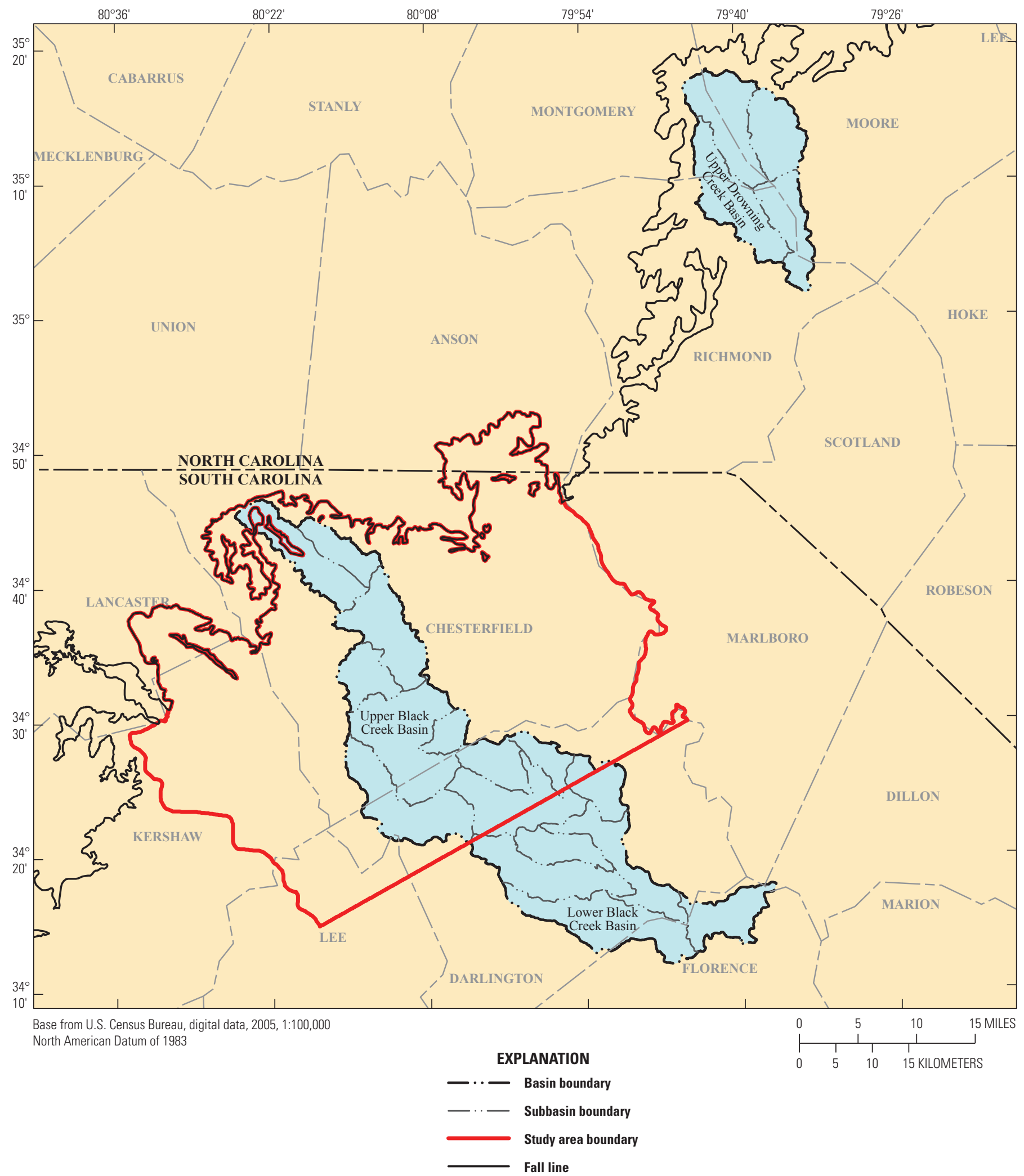

Figure 5. Locations of Black Creek and Upper Drowning Creek Basins, North and South Carolina. 


\section{Physiography}

The Chesterfield County study area is located in the Pee Dee River Basin in South Carolina (fig. 6). Major drainages in the basin include the Pee Dee and Lynches Rivers. Black Creek and Thompson Creek are tributaries that flow into the Pee Dee River and drain parts of the study area (Newcome, 2004b). The rivers, streams, and many other tributaries (fig. 3) are fed by groundwater flow in the study area. Additionally, numerous springs are present in the area. The topography of the study area is characterized by a rolling landscape, with land-surface altitudes that range from 58 feet (ft; North American Vertical Datum 1988 [NAVD 88]) along the Pee Dee River to as much as $722 \mathrm{ft}$ along parts of the Fall Line in northern Chesterfield County (fig. 7) (U.S. Geological Survey, 1999).

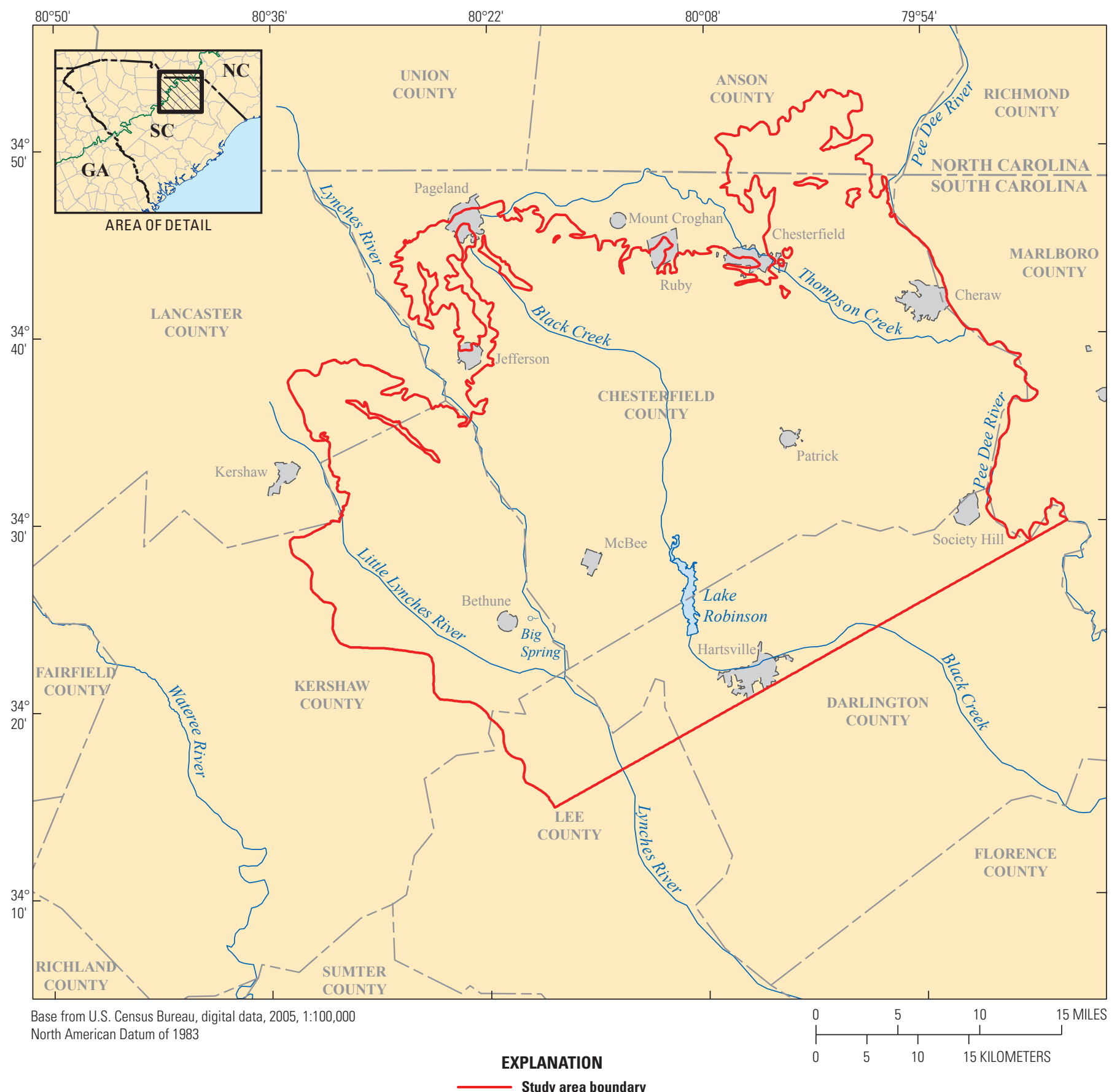

Figure 6. Major rivers and streams in the Chesterfield County area. 


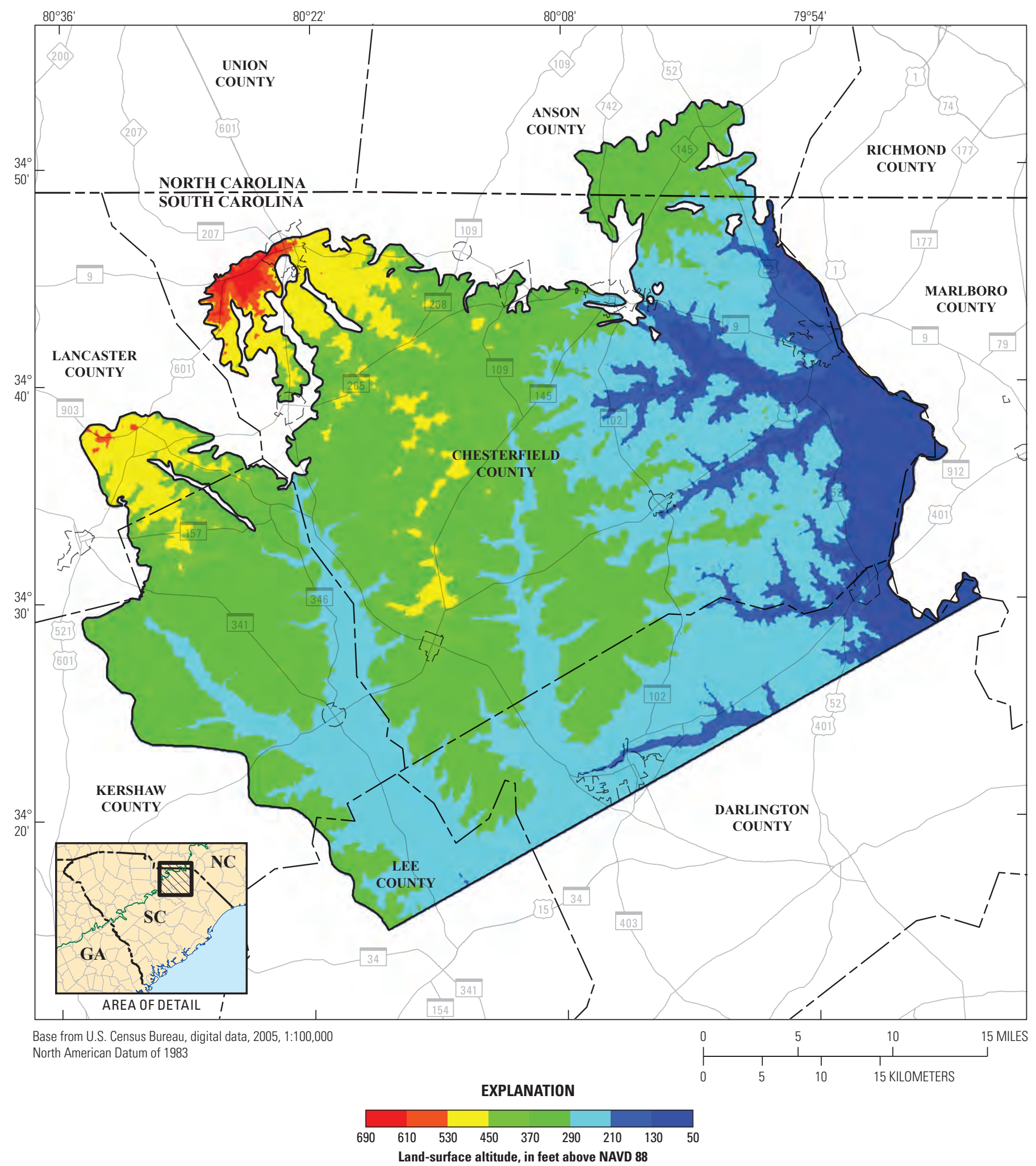

Figure 7. Land-surface altitudes of the Chesterfield County area. 


\section{Land Uses}

The study area has a mixed land use of forest (deciduous, evergreen, and mixed; 40 percent), wetlands (woody and emergent herbaceous; 15 percent), grassland (14 percent), crops (13 percent), pasture (10 percent), developed land ( 7 percent), and open water (1 percent; Fry and others, 2011; fig. 8). Forest lands that cover the study area are composed of the CSNWR, the SSF, and private land holdings. Most of the larger rivers and streams have extensive areas of wetlands along their length. Crops grown in the study area include peaches, strawberries, soybeans, pasture, and sorghum. The study area has little developed land, consisting mostly of small towns and the electrical power generation complex at Lake Robinson (fig. 6). Lake Robinson is the only large open-water body in the study; however, the study area contains numerous small lakes and ponds (commonly springs that have been dammed).

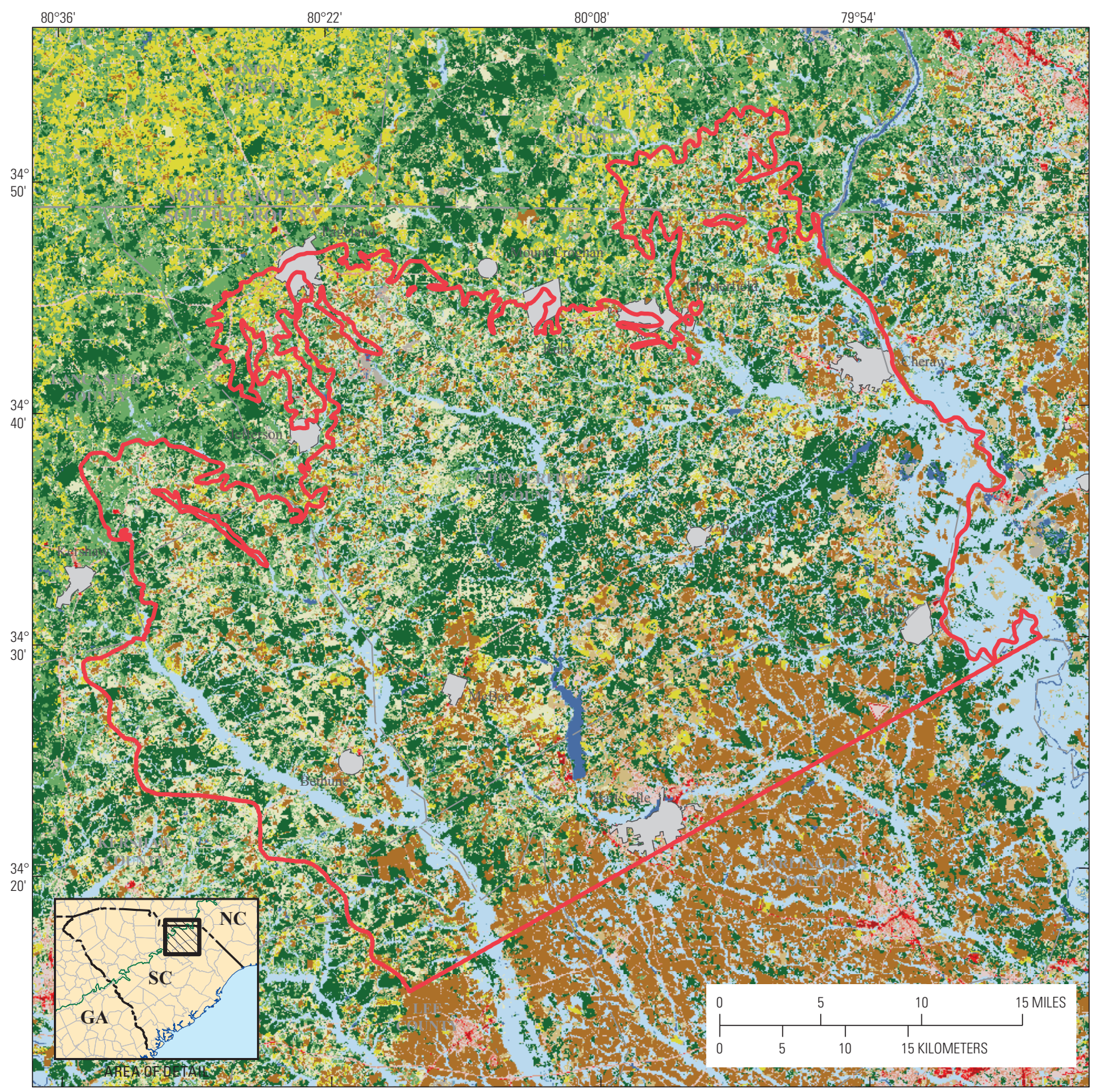

Base from U.S. Census Bureau, digital data, 2005, 1:100,000 North American Datum of 1983
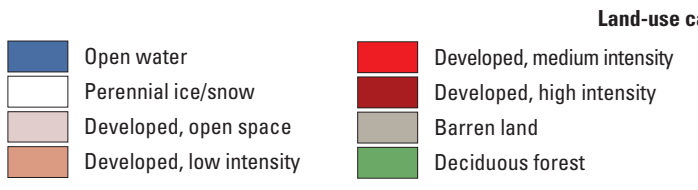

\section{EXPLANATION}
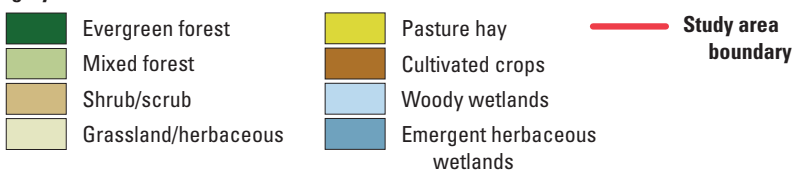

Figure 8. Land use in the Chesterfield County area. (Land-use data from the National Land Cover Database, 2006). 


\section{Geology}

The study area is underlain by Late Cretaceous and younger unconsolidated sands and clays of the Atlantic Coastal Plain (ACP), which in turn overlie various types of crystalline rocks of Paleozoic age of the Piedmont Province. The Piedmont rock types in the study area are thought to be primarily low-grade metamorphic rocks including slates and phyllites (D.C. Prowell, U.S. Geological Survey, retired, written commun., 2000). Depths to bedrock and thickness of the Atlantic Coastal Plain sediments in the McBee, S.C., area were delineated by using a surface geophysical technique (horizontal-to-vertical spectral ratio) (appendix A). The outcropping Late Cretaceous and younger sediments of the upper Atlantic Coastal Plain are mostly micaceous, kaolinitic sands with lenses of clay of variable thickness (Nystrom and others, 1991). The sands are mostly of quartz mineralogy and are coarse, angular to subangular, and poorly sorted. White mica and dark heavy minerals are commonly found, with feldspar grains rarely occurring. Bedding is laterally and vertically discontinuous, and cross bedding is common. Local sandstone ledges are cemented with iron oxide or silica and are present at numerous locations in Chesterfield County.

Atlantic Coastal Plain geologic formations present in the study area are, bottom to top, Cape Fear, Cane Acre, Coachman, Bladen, Donoho Creek, and Peedee Formations (Joseph A. Gellici, South Carolina Department of Natural Resources, written commun., 2013; Gellici and Lautier, 2010). Prowell and others (2003) describe the Bladen Formation of the Black Creek Group (Sohl and Owens, 1991) at a geologic type section near Middendorf in Chesterfield County (fig. 1). At this location, two depositional units are present: a lower fluvial unit and a marginal marine upper unit.

\section{Hydrogeology}

The sediments that compose the aquifers and confining units that underlie Chesterfield County are part of the ACP that extends from New York to Georgia along the eastern seaboard of the United States. A detailed hydrogeologic framework of the ACP in North and South Carolina is presented in Gellici and Lautier (2010), and the following discussion is mostly derived from that framework description. Newcome (2004b) also presents a hydrogeologic framework of Chesterfield County.

The hydrogeologic framework of Chesterfield County consists of two aquifers separated by a confining unit - the Crouch Branch aquifer, the McQueen Branch confining unit, and the McQueen Branch aquifer (fig. 9A, $B, C$ ). The aquifers and confining unit are composed of sedimentary materials, such as gravel, sand, silt, and clay, with some small areas of lithified sandstone, and are Late Cretaceous to younger in age. Thickness of the materials ranges from $0 \mathrm{ft}$ at the Fall Line to approximately $450 \mathrm{ft}$ in the southeasternmost part of the study area (Newcome, 2004b). Biostratigraphic and allostratigraphic data and borehole geophysical logs are used to identify and correlate aquifers and confining units from well to well. Aquifers and confining units are characterized in terms of their lithology, hydrologic properties, and geophysical-log signature (Gellici and Lautier, 2010).

The Crouch Branch aquifer overlies the McQueen Branch confining unit where it exists and is present at land surface over all of the study area. The Crouch Branch aquifer dips to the south-southeast at a rate of 18 feet per mile $(\mathrm{ft} / \mathrm{mi})$ in the western part of the ACP and $2 \mathrm{ft} / \mathrm{mi}$ in the eastern part. The shallow dip in the east is the result of erosion or nondeposition of the upper parts of the aquifer owing to uplift along the Cape Fear arch. The aquifer is also correlated with the Black Creek aquifer system of Colquhoun and others (1983) and with the Black Creek aquifer of Aucott (1988). Sediments that compose the aquifer in Chesterfield County are typically medium- to coarse-grained quartz sands with interbedded clays. The Crouch Branch is a highly productive aquifer in updip parts of the Atlantic Coastal Plain where it is thick and consists of unconsolidated medium- to coarse-grained sand. It is, however, generally less permeable and transmissive than the underlying McQueen Branch aquifer. Results of 21 aquifer tests of the Crouch Branch aquifer in Dillon, Florence, Marion, and Marlboro Counties (Rodriguez and others, 1994) produce transmissivity values that range from about 1,000 to 6,200 square feet per day $\left(\mathrm{ft}^{2} / \mathrm{d}\right)$ and average $2,400 \mathrm{ft}^{2} / \mathrm{d}$ (median of 1,700 ft²/d).

The McQueen Branch confining unit (Gellici and Lautier, 2010) overlies the McQueen Branch aquifer and underlies the Crouch Branch aquifer over most of the SC Atlantic Coastal Plain. In counties along the Fall Line, clay beds composing the confining unit thin and are locally absent. In these areas, the McQueen Branch and Crouch Branch aquifers coalesce and are designated as the Crouch Branch aquifer (fig. 9A). Little hydraulic or lithologic information is available in the Chesterfield County area for the McQueen Branch confining unit.

The McQueen Branch aquifer (Gellici and Lautier, 2010) overlies Piedmont Physiographic Province bedrock in the Chesterfield County area. The aquifer dips to the southsoutheast at a rate of about $8 \mathrm{ft} / \mathrm{mi}$ in the eastern part of the SC Atlantic Coastal Plain. In updip regions of the SC Atlantic Coastal Plain, the McQueen Branch aquifer consists of all or parts of three formations that, in ascending order, are the upper part of the Cape Fear (late Turonian to Coniacian), the Cane Acre (middle Campanian), and the lower part of the Coachman (middle Campanian) (Gellici and Lautier, 2010). Most of the aquifer in updip regions consists of the Cane Acre Formation. The McQueen Branch aquifer is correlated with the Middendorf aquifer of Aucott (1988) in updip regions and with the Middendorf aquifer system of Colquhoun and others (1983). The McQueen Branch aquifer is characterized by unconsolidated, poorly sorted fine- to coarse-grained sand and clayey sand with local gravel. The sand fraction consists of quartz with sparse carbonaceous material, mica, feldspar, and monazite.

The McQueen Branch aquifer is one of the most productive in the SC Atlantic Coastal Plain, especially in the west-central and updip parts of the ACP where it is thick and consists of 
unconsolidated coarse-grained sand. Generally, the aquifer thins to the east and south where it is less permeable. To the east, 27 aquifer tests made in Darlington, Dillon, Florence, Marion, and Marlboro Counties (Rodriguez and others, 1994) resulted in transmissivity values that range from 300 to $9,100 \mathrm{ft}^{2} / \mathrm{d}$ and average $3,800 \mathrm{ft}^{2} / \mathrm{d}$ (median of 2,500 $\mathrm{ft}^{2} / \mathrm{d}$ ). In Chesterfield County, Newcome (2004b) presents aquifer test results for 13 wells screened primarily in the McQueen Branch aquifer. Results of these tests give a minimum horizontal hydraulic conductivity of 3 feet per day (ft/d) and a maximum of $87 \mathrm{ft} / \mathrm{d}$, with a standard deviation of $26 \mathrm{ft} / \mathrm{d}$.

\section{Springs}

Mitchell (2004) documents several of the numerous springs in the study area. These springs are present where the water table intersects the land surface. The headwaters of most of the streams in the study area are technically springs, although generally the springs of interest are those that flow out of rock or the ground in such amounts as to be useful or at least noticeable. One of the springs described by Mitchell (2004) in the study area is Big Spring, located on the banks of the Lynches River just downstream from the U.S. Highway 1 crossing (fig. 1).

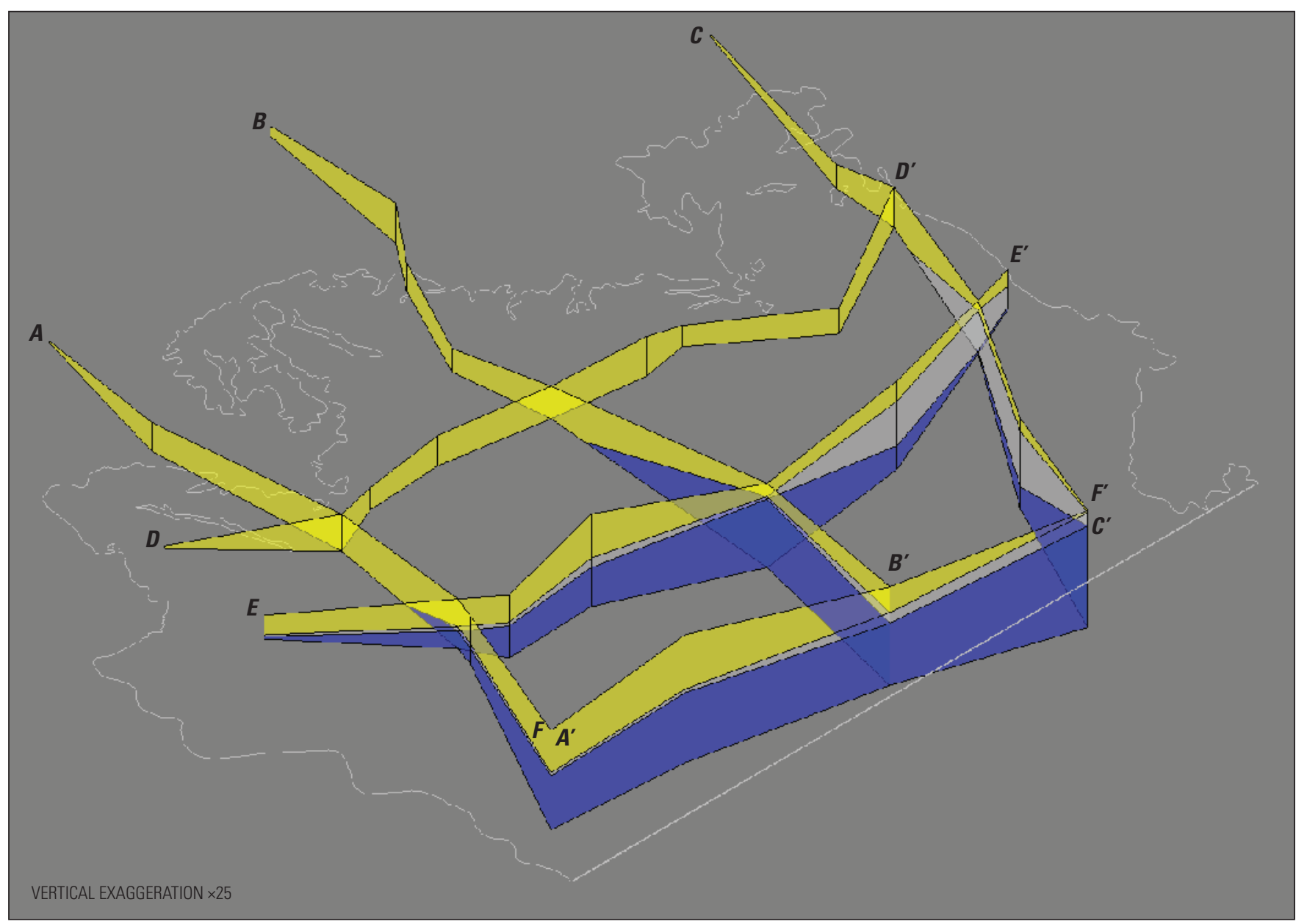

\section{EXPLANATION}

Crouch Branch aquifer

McQueen Branch confining unit

McQueen Branch aquifer

$\boldsymbol{A}-\boldsymbol{A}^{\prime}$ Line of section

Figure 9A. Hydrogeologic framework of the Chesterfield County area.

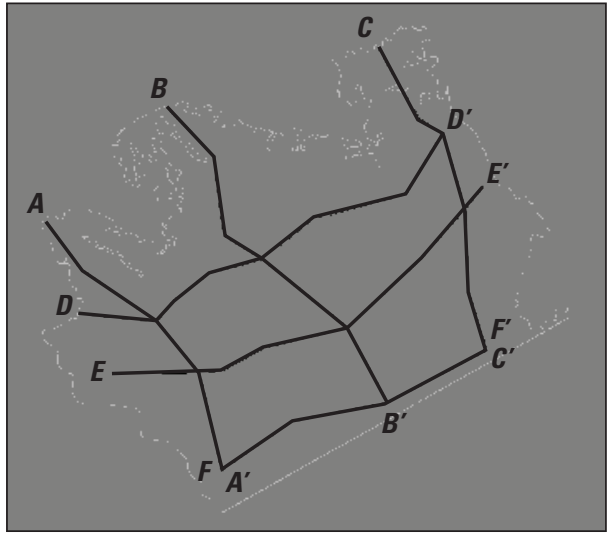




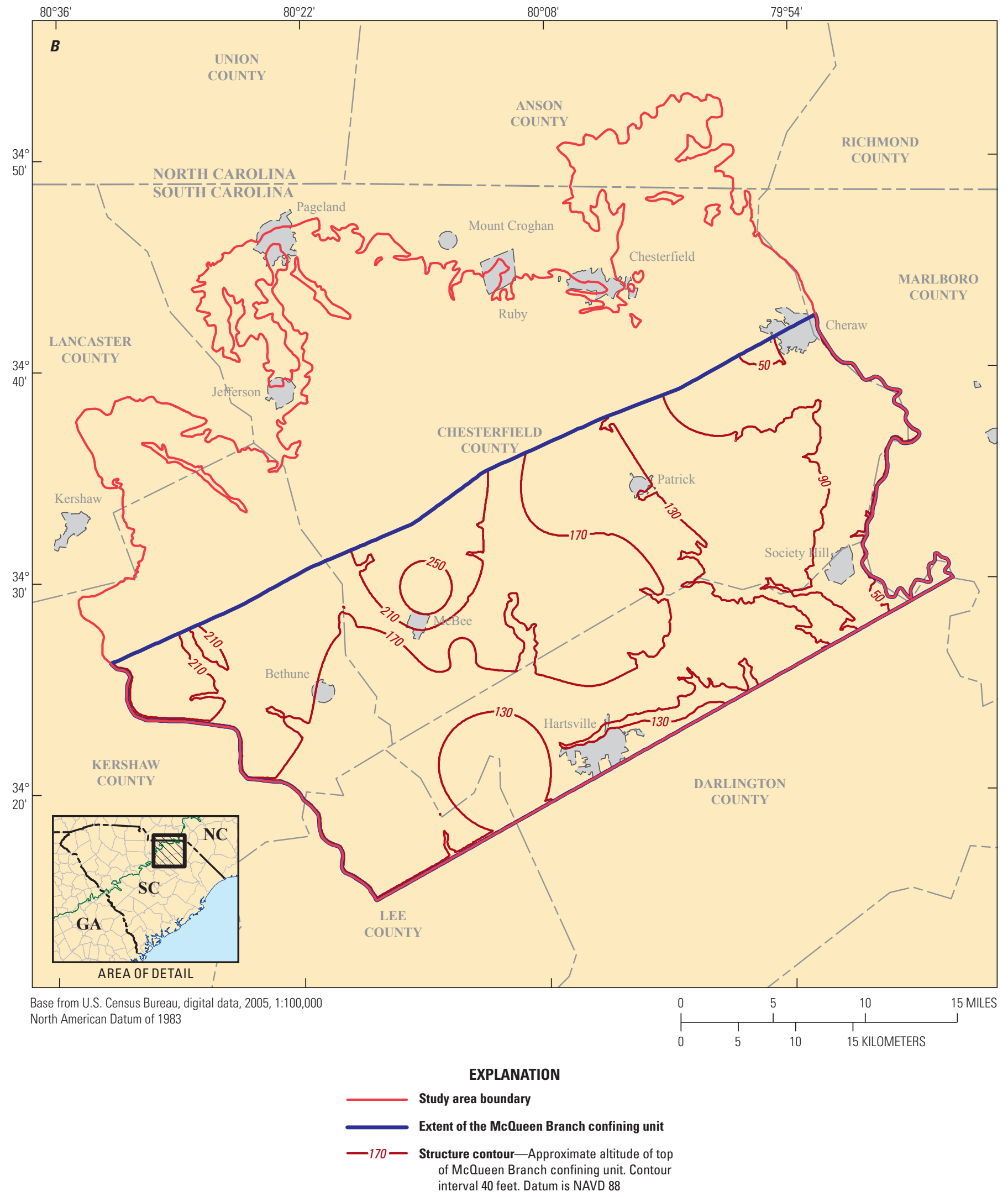

Figure $\mathbf{9 B}$. Areal extent and altitude of the top of the McQueen Branch confining unit, Chesterfield County area. 


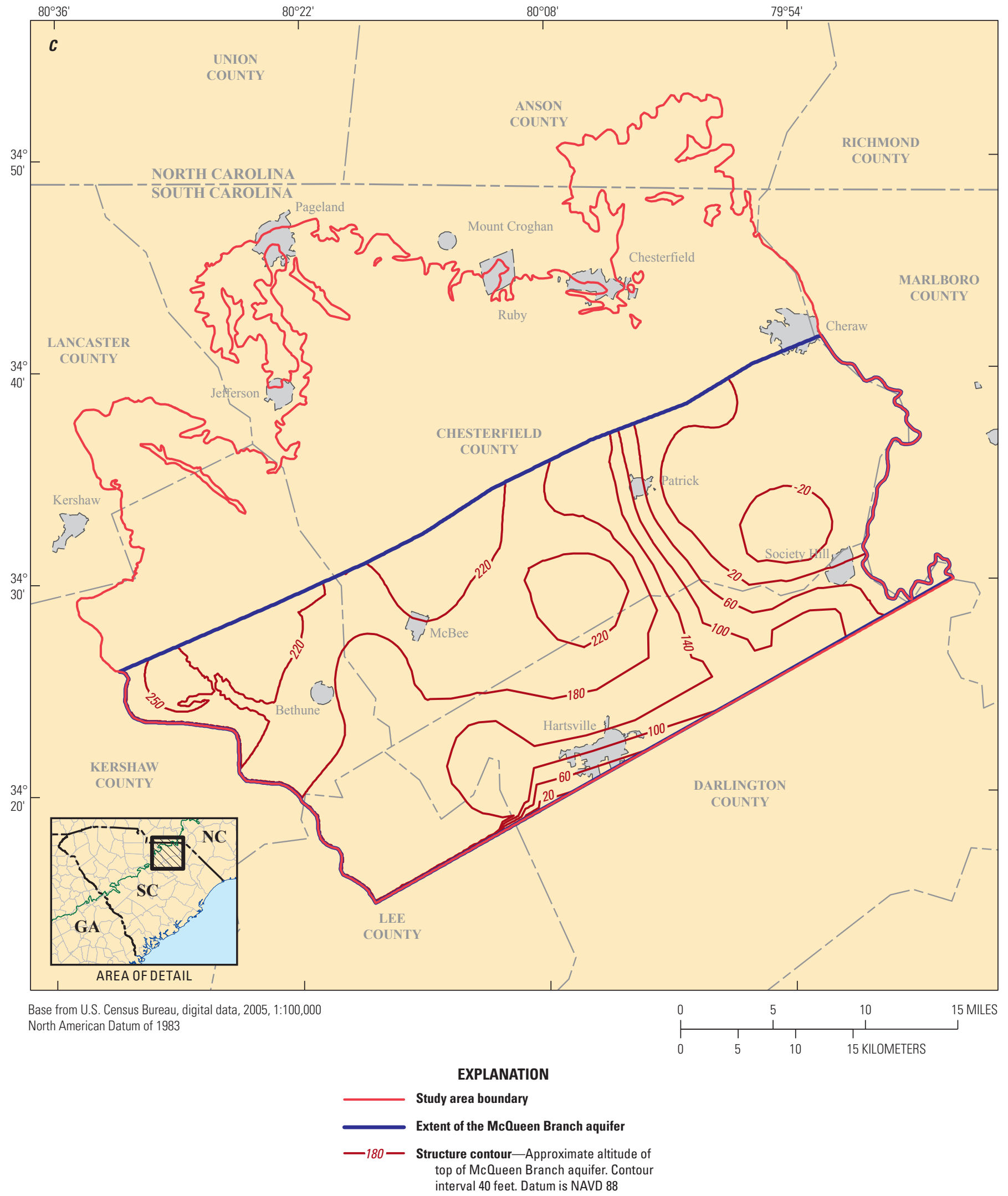

Figure 9C. Areal extent and altitude of the top of the McQueen Branch aquifer, Chesterfield County area. 


\section{Methods of Data Collection and Analysis Well Network}

This groundwater assessment of the Chesterfield County area involved the collection, integration, and use of new and existing data, along with the construction and calibration of a groundwater-flow model. The model is the primary tool used in the assessment of groundwater availability of the study area. The results, conclusions, and limitations discussed in this report are based on the analyses of these data along with the interpretation of results from the groundwater-flow model.

Major types of data used in the study include (1) groundwater levels, synoptic and continuous types; (2) groundwateruse data, consisting of estimated and recorded groundwater pumping rates, locations, and aquifer assignments;

(3) hydrostratigraphic data such as aquifer and confining unit thicknesses; (4) estimates of base flows derived from the analysis of observed stream base flows at selected sites; and (5) precipitation data. Historical groundwater levels, groundwater-use data, precipitation data, and streamflows were compiled for the period 1900 to 2012 and used in the model construction and calibration process.

A finite-difference numerical modeling technique (MODFLOW-2000; Harbaugh and others, 2000) was used to simulate groundwater flow in the aquifers and confining unit of the study area over a 112-year period from 1900 to 2012. The methods of investigation used in the modeling effort included conceptual model evaluation and revision, data compilation, model construction and calibration, and sensitivity analysis. The existing conceptual models were evaluated to determine the appropriateness of boundary conditions, model layering, and methods of approximating field conditions. Aquifer properties, water-use data, and groundwaterlevel data for 1900 to 2012 were compiled from various State agencies and other USGS investigations for inclusion in the model. The model was calibrated by approximating steady-state, predevelopment, groundwater conditions prior to 1900 and simulating transient conditions from 1900 to 2012 by using multiple stress periods that included pumping. The sensitivity of the calibrated model to the modeled parameters was evaluated to determine the relative importance of the parameters to simulated results. These modeling techniques produced groundwater altitudes and flow directions that were statistically compared to field measurements of groundwater altitudes. Water budgets were derived from the model for selected areas and analyzed.
Several different types of wells were used in the data collection effort that included production, irrigation (agricultural), domestic-supply, and monitoring wells (fig. 10). Data from production wells near the cities of McBee, Patrick, Bethune, Hartsville, and Society Hill and Darlington County consisted of groundwater levels, hydrostratigraphic data, and historical water-use data. Data from agricultural irrigation wells, screened in the Crouch Branch and McQueen Branch aquifers, in the vicinity of $\mathrm{McBee}$ consisted of groundwater levels and historical water-use data. These wells are used to seasonally irrigate various crops, including fruits and vegetables. Data from domestic-supply wells throughout the study area consisted of historic groundwater levels and hydrostratigraphic data. Most of these domestic-supply wells are screened in the Crouch Branch aquifer. Monitoring wells drilled as part of this project and other publicly and privately owned monitoring wells were used to obtain continuous and historical groundwater levels and hydrostratigraphic data.

Four monitoring wells were installed as part of this project (fig. 11). Well CTF-197 (USGS site 343907080164400 ) was drilled in the northern part of the CSNWR. This well is $130 \mathrm{ft}$ deep and is screened in the Crouch Branch aquifer. Groundwater levels from the well were recorded hourly from May 2008 to July 2013. Wells CTF-221 (342543080165801) and CTF-222 (342543080165800) were installed as a nested well pair and are located on Blackwell Farm Road about 2 miles (mi) southwest of McBee, S.C. Well CTF-221 is $260 \mathrm{ft}$ deep and is screened in the McQueen Branch aquifer. Well CTF-222 is $171 \mathrm{ft}$ deep and is screened in the Crouch Branch aquifer. Groundwater levels were recorded hourly at both wells from August 2008 to December 2013. Well CTF-228 (342828080131900) is located about 1 mi east of McBee. Well CTF-228 was drilled in October 2010, is $335 \mathrm{ft}$ deep, and is screened in the McQueen Branch aquifer.

\section{Ground water-Level Measurements}

Groundwater-level measurements were a key part of the data collection effort for this study and were used primarily in the groundwater-flow model calibration process. Historical groundwater levels were retrieved from the USGS National Water Information System database, from the SCDNR WellTab database (Andy Wachob, South Carolina Department of Natural Resources, written commun., 2012), and from SCDHEC files of domestic well records (Jim Hess, South Carolina Department of Health and Environmental Control, retired, written commun., 2009). Groundwater level altitudes from 154 wells open to the Crouch Branch aquifer were used, along with 85 groundwater level altitudes from wells screened in the McQueen Branch aquifer (fig. 12A, $B$ ). These water levels range in altitude from $69 \mathrm{ft}$ NAVD 88 to $555 \mathrm{ft}$, for a range of $487 \mathrm{ft}$. 


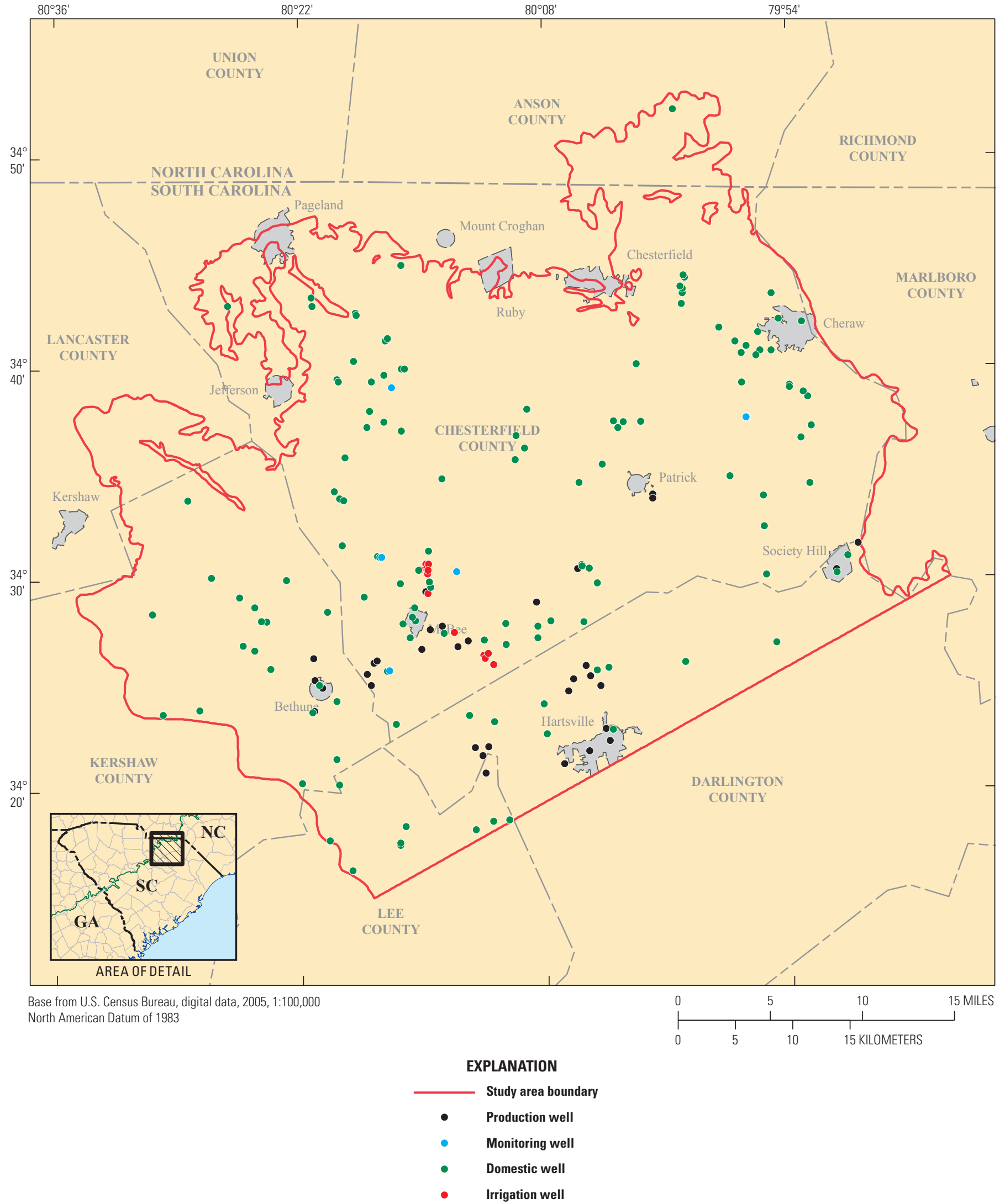

Figure 10. Locations of production, irrigation, domestic, and monitoring wells used in this study, Chesterfield County area. 


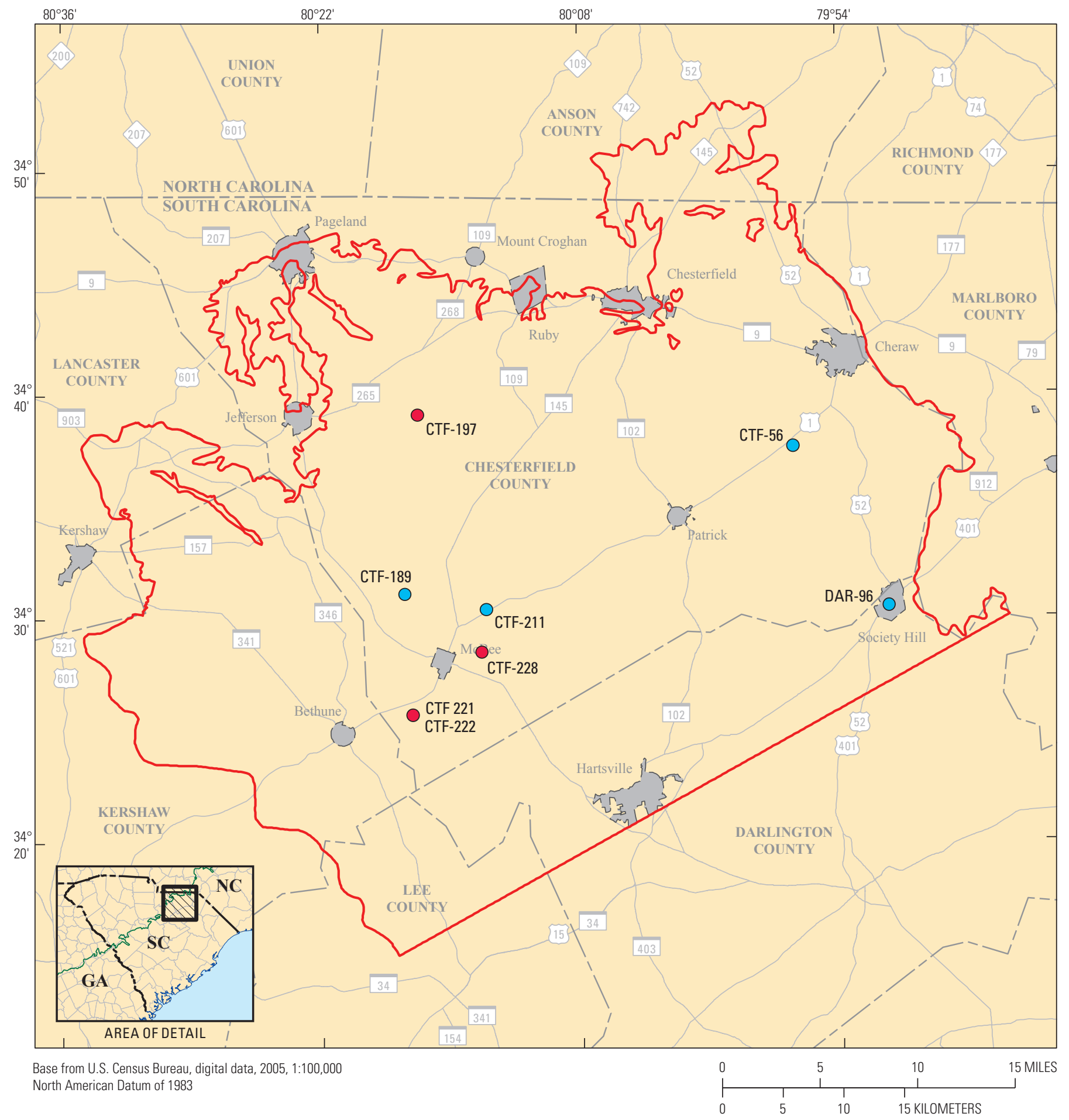

EXPLANATION

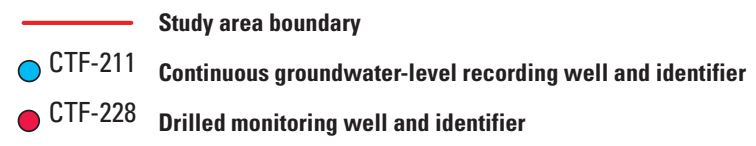

Figure 11. Locations of groundwater observation wells drilled for the study and wells used for continuous groundwater-level recording, Chesterfield County area. 


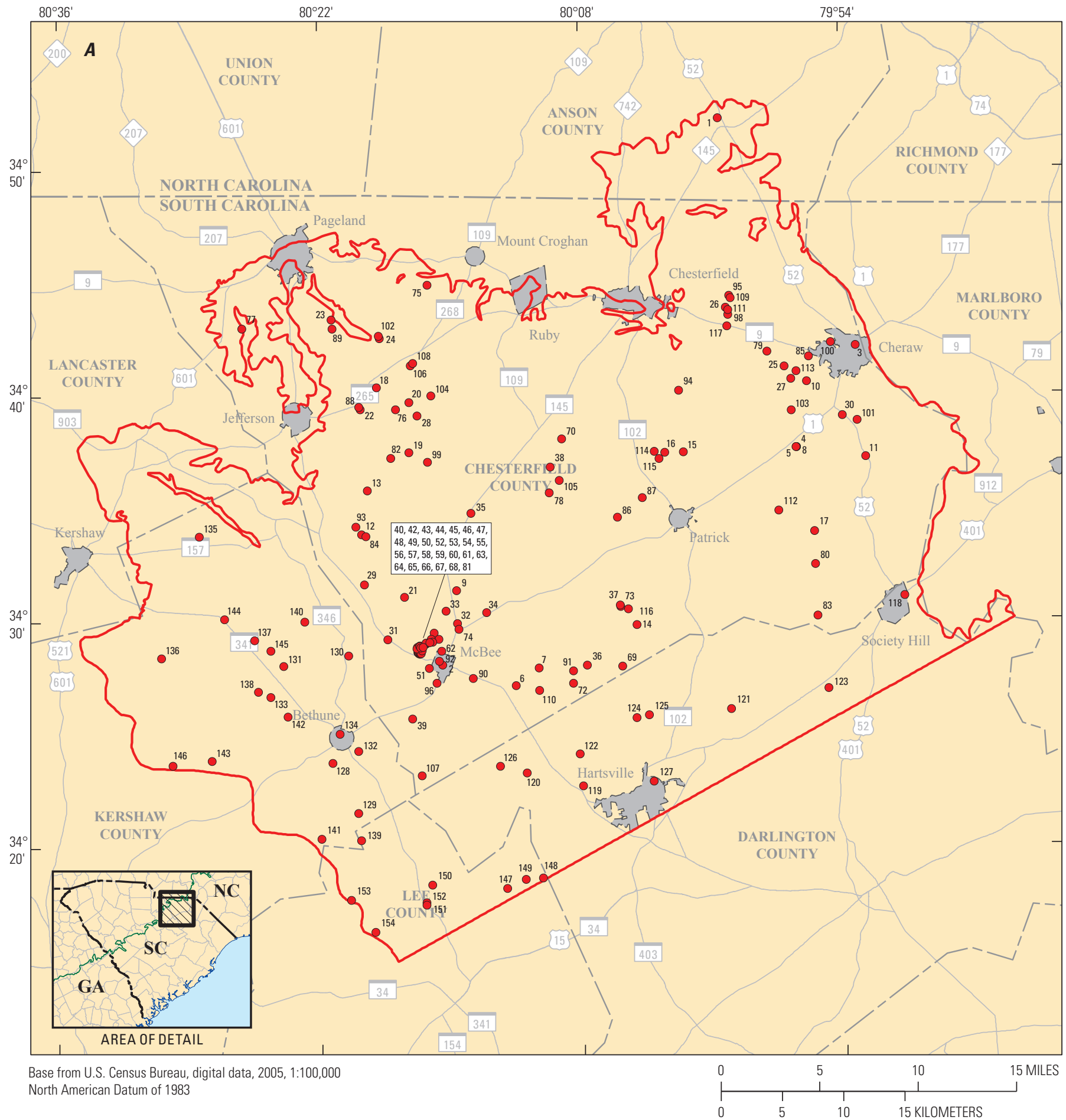

EXPLANATION

Study area boundary

$\odot_{90} \quad$ Location and identifier of well located in the Crouch Branch aquifer

Figure 12A. Locations of wells with groundwater-level measurements from the Crouch Branch aquifer used in this study, Chesterfield County area. 


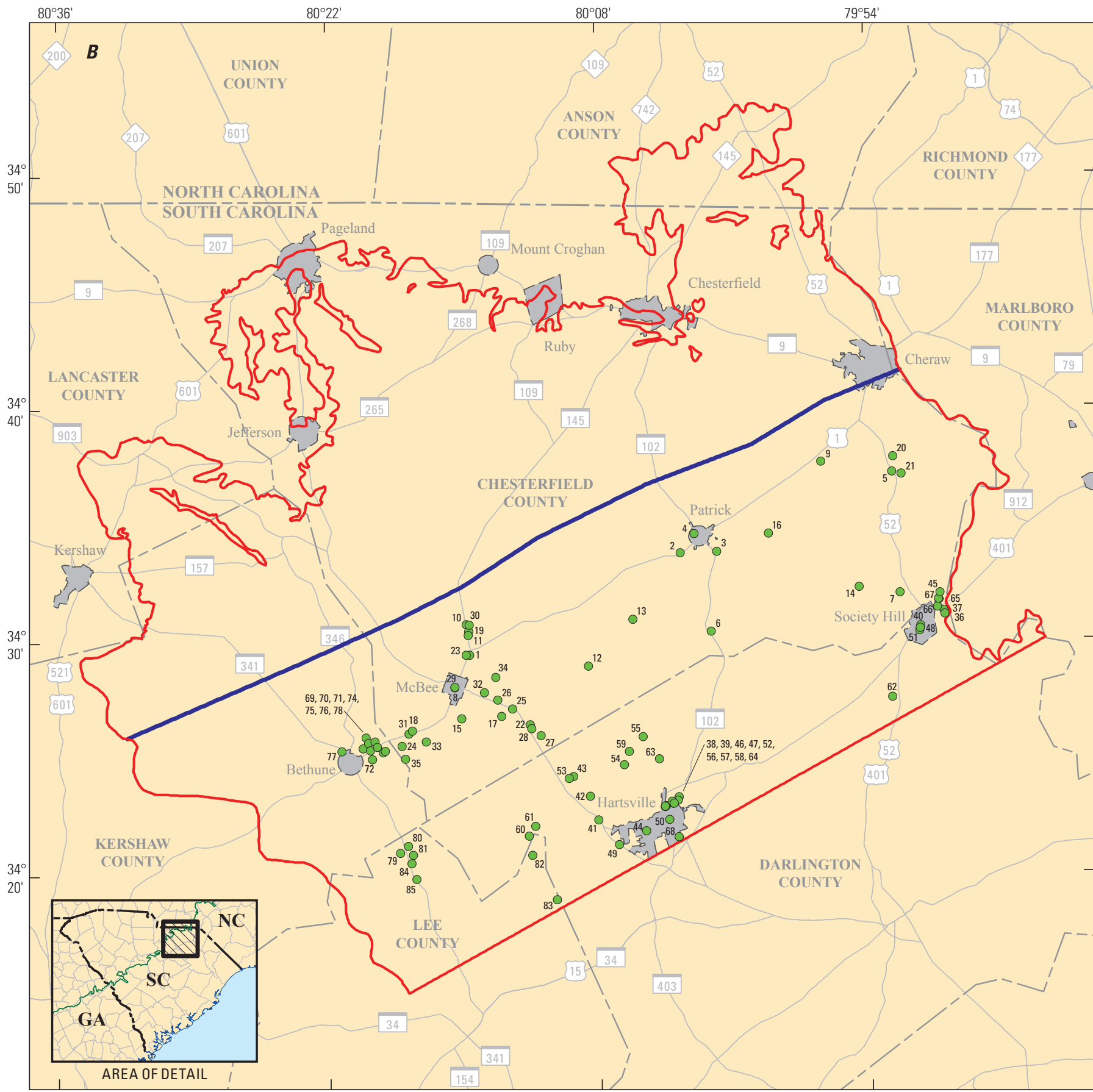

Base from U.S. Census Bureau, digital data, 2005, 1:100,000 North American Datum of 1983

EXPLANATION

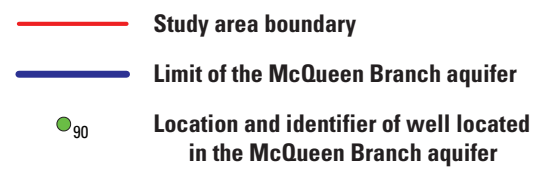

Figure 12B. Locations of wells with groundwater-level measurements from the McQueen Branch aquifer used in this study, Chesterfield County area. 


\section{Streamflow Measurements}

Streamflow measurements from 44 sites (fig. 13; table 1) were used during model construction. Several types of streamflow measurements were used:(1) hourly stage values (from which discharge or streamflow is calculated) that are transmitted in near real time; (2) low-flow measurements that are documented in several studies (Bloxham, 1976, 1979;
Barker, 1986; Zalants, 1991); and (3) discrete streamflow measurements made specifically as part of this study, some of which are at the low-flow measurement sites and others at sites where no previous data had been collected.

These streamflow discharge measurements ranged from about 10,000 cubic feet per day $\left(\mathrm{ft}^{3} / \mathrm{d}\right)$ to about $23,000,000 \mathrm{ft}^{3} / \mathrm{d}$. Streamflow data from one of the long-term (50 years) gaging stations were used in hydrograph separation analyses to

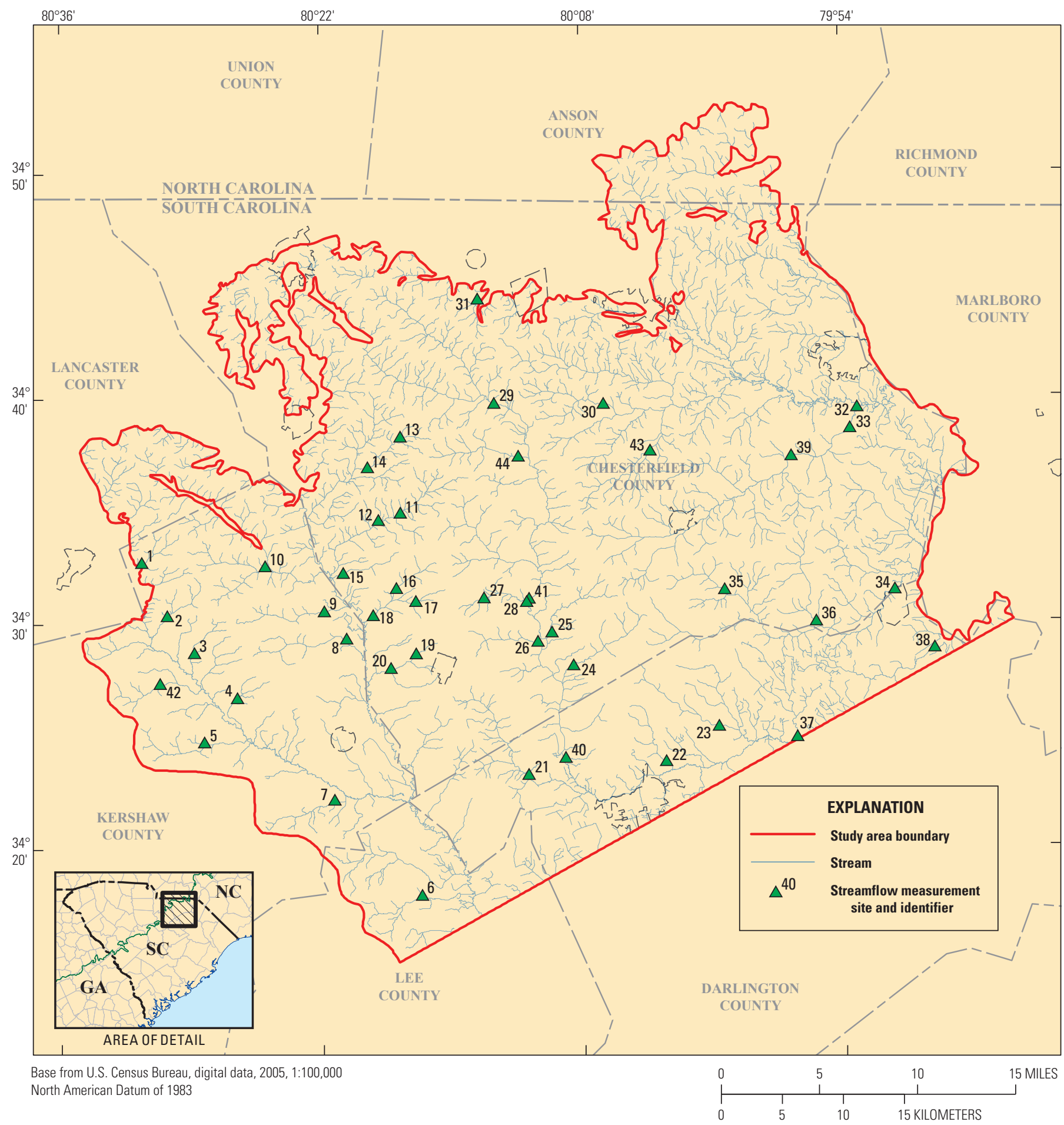

Figure 13. Locations of streamflow measurement sites, Chesterfield County area. 
calculate base flow derived from groundwater discharge. USGS site 02130900, Black Creek near McBee, S.C., (fig. 13, site 41) was chosen for analysis because of the length of record and the absence of upstream flow regulation. Two hydrograph separation programs were applied to the daily streamflow data from the site: PART (Rutledge, 1998) and HYSEP (Sloto and Crouse, 1996). Two different HYSEP methods were used, the minima method and the digital filtering method, which resulted in three total methods being used for the hydrograph separation analysis. These three methods resulted in an average base-flow index of 76 percent, which means that 76 percent of the measured streamflow is derived from groundwater discharge and 24 percent is from overland flow. All of the streamflow measurements were corrected using the 76-percent index.

Table 1. Streamflow measurement sites in the Chesterfield County area.

[Map index number is referenced to figure 13; $\mathrm{ft}^{3} / \mathrm{d}$, cubic feet per day; $\mathrm{n} / \mathrm{a}$, not applicable; NWIS, National Water Information System]

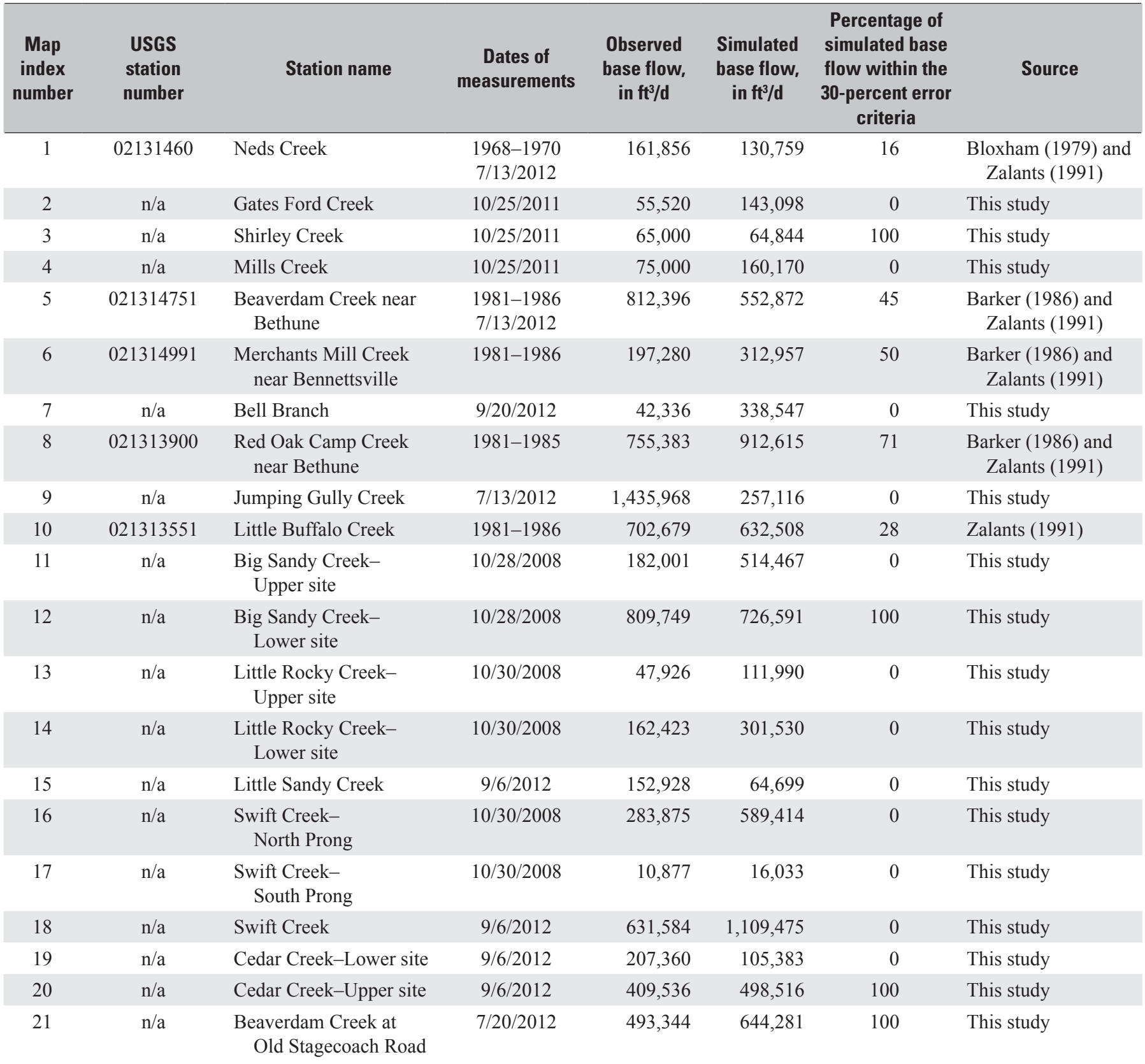


Table 1. Streamflow measurement sites in the Chesterfield County area.-Continued

[Map index number is referenced to figure 13; ft³/d, cubic feet per day; n/a, not applicable; NWIS, National Water Information System]

\begin{tabular}{|c|c|c|c|c|c|c|c|}
\hline $\begin{array}{c}\text { Map } \\
\text { index } \\
\text { number }\end{array}$ & $\begin{array}{l}\text { USGS } \\
\text { station } \\
\text { number }\end{array}$ & Station name & $\begin{array}{c}\text { Dates of } \\
\text { measurements }\end{array}$ & $\begin{array}{c}\text { Observed } \\
\text { base flow, } \\
\text { in } \mathrm{ft}^{3} / \mathrm{d}\end{array}$ & $\begin{array}{l}\text { Simulated } \\
\text { base flow, } \\
\text { in } \mathrm{ft}^{3} / \mathrm{d}\end{array}$ & $\begin{array}{c}\text { Percentage of } \\
\text { simulated base } \\
\text { flow within the } \\
30 \text {-percent error } \\
\text { criteria }\end{array}$ & Source \\
\hline 22 & 021309151 & Spring Branch & $1981-1986$ & 306,720 & 133,907 & 0 & $\begin{array}{c}\text { Barker (1986) and } \\
\text { Zalants (1991) }\end{array}$ \\
\hline 23 & 021309201 & Boggy Swamp & $\begin{array}{c}1981-1986 \\
7 / 20 / 2012\end{array}$ & 776,736 & 547,473 & 9 & $\begin{array}{c}\text { Barker (1986) and } \\
\text { Zalants (1991) }\end{array}$ \\
\hline 24 & $\mathrm{n} / \mathrm{a}$ & $\begin{array}{l}\text { Big Beaverdam Creek } \\
\text { at Middendorf Road }\end{array}$ & $9 / 20 / 2012$ & 648,000 & 34,151 & 0 & This study \\
\hline 25 & $\mathrm{n} / \mathrm{a}$ & $\begin{array}{c}\text { Little Beaverdam Creek } \\
\text { at Middendorf Road }\end{array}$ & $9 / 20 / 2012$ & 302,400 & 135,240 & 0 & This study \\
\hline 26 & $\mathrm{n} / \mathrm{a}$ & Lower Alligator Creek & $\begin{array}{l}10 / 28 / 2008 \\
7 / 20 / 2012\end{array}$ & 545,629 & 569,151 & 100 & This study \\
\hline 27 & $\mathrm{n} / \mathrm{a}$ & $\begin{array}{l}\text { Little Alligator Creek- } \\
\text { Upper site }\end{array}$ & $10 / 29 / 2008$ & 61,456 & 7,762 & 0 & This study \\
\hline 28 & $\mathrm{n} / \mathrm{a}$ & $\begin{array}{l}\text { Little Alligator Creek- } \\
\text { Lower site }\end{array}$ & $\begin{array}{c}10 / 29 / 2008 \\
11 / 8 / 2012\end{array}$ & 309,839 & 266,229 & 100 & This study \\
\hline 29 & 02130840 & $\begin{array}{l}\text { Black Creek below } \\
\text { Chesterfield, SC }\end{array}$ & $2006-2012$ & $3,598,277$ & $3,795,855$ & 33 & NWIS \\
\hline 30 & $\mathrm{n} / \mathrm{a}$ & Little Bear Creek & $10 / 30 / 2008$ & 205,891 & 926,676 & 0 & Barker (1986) \\
\hline 31 & $\mathrm{n} / \mathrm{a}$ & Jennings Branch & $10 / 25 / 2012$ & 45,000 & 85,701 & 0 & This study \\
\hline 32 & $\mathrm{n} / \mathrm{a}$ & Thompson Creek & $10 / 3 / 2012$ & $13,392,000$ & $8,827,871$ & 0 & This study \\
\hline 33 & 02130500 & $\begin{array}{l}\text { Juniper Creek near } \\
\text { Cheraw, SC }\end{array}$ & $1941-1958$ & $6,268,320$ & $5,318,816$ & 61 & NWIS \\
\hline 34 & 02130600 & $\begin{array}{l}\text { Cedar Creek at } \\
\text { Society Hill, SC }\end{array}$ & 1949-1981 & $4,844,926$ & $5,250,480$ & 32 & NWIS \\
\hline 35 & 021305941 & $\begin{array}{l}\text { Little Cedar Creek } \\
\text { near Patrick }\end{array}$ & $1981-1986$ & 575,424 & 352,733 & 33 & $\begin{array}{c}\text { Barker (1986) and } \\
\text { Zalants (1991) }\end{array}$ \\
\hline 36 & 021305971 & $\begin{array}{l}\text { Harris Creek near } \\
\text { Society Hill }\end{array}$ & $1970-1986$ & $2,284,488$ & 735,224 & 16 & $\begin{array}{c}\text { Barker (1986) and } \\
\text { Zalants (1991) }\end{array}$ \\
\hline 37 & $\mathrm{n} / \mathrm{a}$ & Seed Branch & $9 / 20 / 2012$ & 812,160 & 298,065 & 0 & $\begin{array}{c}\text { Barker (1986) and } \\
\text { Zalants (1991) }\end{array}$ \\
\hline 38 & 021307101 & $\begin{array}{l}\text { Buckholtz Creek near } \\
\text { Society Hill }\end{array}$ & $1981-1986$ & 542,016 & 723,960 & 33 & $\begin{array}{c}\text { Barker (1986) and } \\
\text { Zalants (1991) }\end{array}$ \\
\hline 39 & $\mathrm{n} / \mathrm{a}$ & Juniper Creek & $\begin{array}{c}10 / 28 / 2008 \\
11 / 8 / 2012\end{array}$ & $6,021,492$ & $3,315,522$ & 50 & This study \\
\hline 40 & 02130910 & $\begin{array}{c}\text { Black Creek near } \\
\text { Hartsville, SC }\end{array}$ & $1961-2012$ & $17,596,847$ & $17,303,358$ & 92 & NWIS \\
\hline 41 & 02130900 & $\begin{array}{l}\text { Black Creek near } \\
\text { McBee, SC }\end{array}$ & $1960-2012$ & $12,376,066$ & $10,896,438$ & 76 & NWIS \\
\hline 42 & 021314701 & $\begin{array}{l}\text { Cow Branch near } \\
\text { Kershaw }\end{array}$ & $\begin{array}{c}1981-1986 \\
7 / 13 / 2012\end{array}$ & 589,989 & 470,703 & 42 & Barker (1986) \\
\hline 43 & $\mathrm{n} / \mathrm{a}$ & Mount Prong Creek & $\begin{array}{c}10 / 29 / 2008 \\
11 / 8 / 2012\end{array}$ & 537,352 & 695,650 & 100 & Barker (1986) \\
\hline 44 & 021308601 & Skipper Creek & 1981-1986 & 485,309 & 660,124 & 40 & Barker (1986) \\
\hline
\end{tabular}




\section{Groundwater-Flow Model}

A finite-difference numerical groundwater-flow model of the Crouch Branch aquifer, McQueen Branch confining unit, and McQueen Branch aquifer in the Chesterfield County area was constructed and calibrated using the conceptualizations and data previously discussed. This section documents (1) the development of the transient, three-dimensional, finite-difference numerical flow model; (2) the procedure used to calibrate the groundwater-flow model; (3) a summary of the model results; (4) and a discussion of model uncertainty and limitations. The simulation incorporates time-varying stresses and can be used to evaluate the effects of climatic and anthropogenic temporal changes in recharge and discharge on the hydrologic system between 1900 and 2012.

Groundwater flow in the ACP aquifers of Chesterfield County was simulated by using MODFLOW-2000 (Harbaugh and others, 2000), referred to in this report as MODFLOW. MODFLOW simulates an aquifer as porous media; that is, water is assumed to move through small pores, such as the void space between sand grains. In this type of simulation, an aquifer is considered to be saturated and groundwater flow is considered to be Darcian (nonturbulent) flow. If these conditions are met, then the mathematical treatment of this type of flow is well understood and well developed. Many different computer codes exist to simulate flow that meets these conditions, but MODFLOW is one of the most commonly used (Leake, 1997). The ACP aquifers of Chesterfield County are composed of sand, silt, and clay and are considered ideal for the use of MODFLOW as a groundwater-flow simulation tool.

MODFLOW was used to simulate groundwater flow in the ACP aquifers of Chesterfield County for many reasons. (1) The finite-difference method used by MODFLOW is easy to understand and apply to a wide variety of real-world conditions. (2) Each simulation feature of MODFLOW has been extensively tested. (3) Data input instructions and theory are well documented (Leake, 1997). (4) A wide variety of computer programs written by the USGS, other Federal agencies, and private companies are available to analyze field data and construct input datasets for MODFLOW (Leake, 1997).

(5) A wide variety of programs are available to read output from MODFLOW and graphically present model results in ways that are easily understood. (6) MODFLOW has been accepted in many court cases in the United States as a legitimate approach to analysis of groundwater systems (Leake, 1997).

MODFLOW uses a finite-difference approach to solving the equations that describe groundwater flow. A finitedifference approach solves equations by replacing the equations at a point, known as a node, by ratios of the changes in appropriate variables over a small but finite interval (Harbaugh and others, 2000). The volume of the aquifer described by the model is divided into cells, and a node is in each cell; MODFLOW locates the node at the cell center. The time of the simulation must be discretized into time intervals to use finite-difference methods for transient analyses. The process of dividing the model volume into cells and time into intervals is referred to as discretization. All of the aquifers and confining units are simulated as confined in the MODFLOW model.

A commercial graphical user interface was used to prepare the MODFLOW input files and visualize the model inputs and outputs. This interface provides a means to comprehensively manage all of the data associated with the model.

\section{Model Geometry and Discretization}

The model grid consists of the lateral discretization of the model domain into rows and columns and the vertical discretization of the unconsolidated ACP sediments into layers. The MODFLOW finite-difference grid consists of 617 rows from north to south extending $35 \mathrm{mi}$ and 884 columns from west to east extending $50 \mathrm{mi}$ (fig. 14), yielding a total area of $1,750 \mathrm{mi}^{2}$. However, the active part of the model totaled $1,117 \mathrm{mi}^{2}$. The spacing of the rows and columns is uniform, $300 \mathrm{ft}$ by $300 \mathrm{ft}$, and was chosen to maximize the potential for accurate simulations of groundwater interaction with surface water. Vertically, the ACP sediments were discretized into three layers. Of the total possible active model cells $(1,636,284)$, there are 733,662 cells (or about 45 percent) that were used to actively simulate groundwater flow in the study area. Because the finite-difference grid must be square or rectangular, placement of boundary conditions such as the extent of various aquifers or the Pee Dee River requires that many model cells be inactive.

The MODFLOW model was constructed to use variable time intervals ranging from 1 to 10 years (fig. 15). This time discretization primarily reflects the availability and quality of groundwater-use data. Few groundwater-use data are available until 1980, when the modeled time interval becomes smaller ( 2 years to 1 year). The first 7 stress periods (1900 to 1960) are 10 years in length, the next 4 stress periods (1965 to 1980) are 5 years in length, the next 4 stress periods (1982 to 1988) are 2 years in length, and the last 24 stress periods (1989-2012) are 1 year in length.

\section{Conceptual Model of the Groundwater- Flow System}

A conceptual model of the groundwater-flow system of the ACP sediments in Chesterfield County was developed as the basis for constructing a digital groundwater-flow model (fig. 16). The conceptual model is based on recharge, surface topography, properties, and distribution of the hydrostratigraphic units, groundwater-level data, stream base-flow data, hydrologic testing results, geochemical data, and previously published interpretations of the flow system. The Crouch Branch and McQueen Branch hydrostratigraphic units in the study area are the principal water-bearing units. Recharge to 
hydrostratigraphic units in the study area is from atmospheric precipitation that infiltrates through the surficial materials of the Crouch Branch aquifer at land surface. The Crouch Branch aquifer discharges water to springs, streams, rivers, and wells.
The deeper McQueen Branch aquifer does not crop out in the study area and discharges water to wells. Some water from both aquifers flows laterally out of the study area downdip toward the Atlantic Ocean.

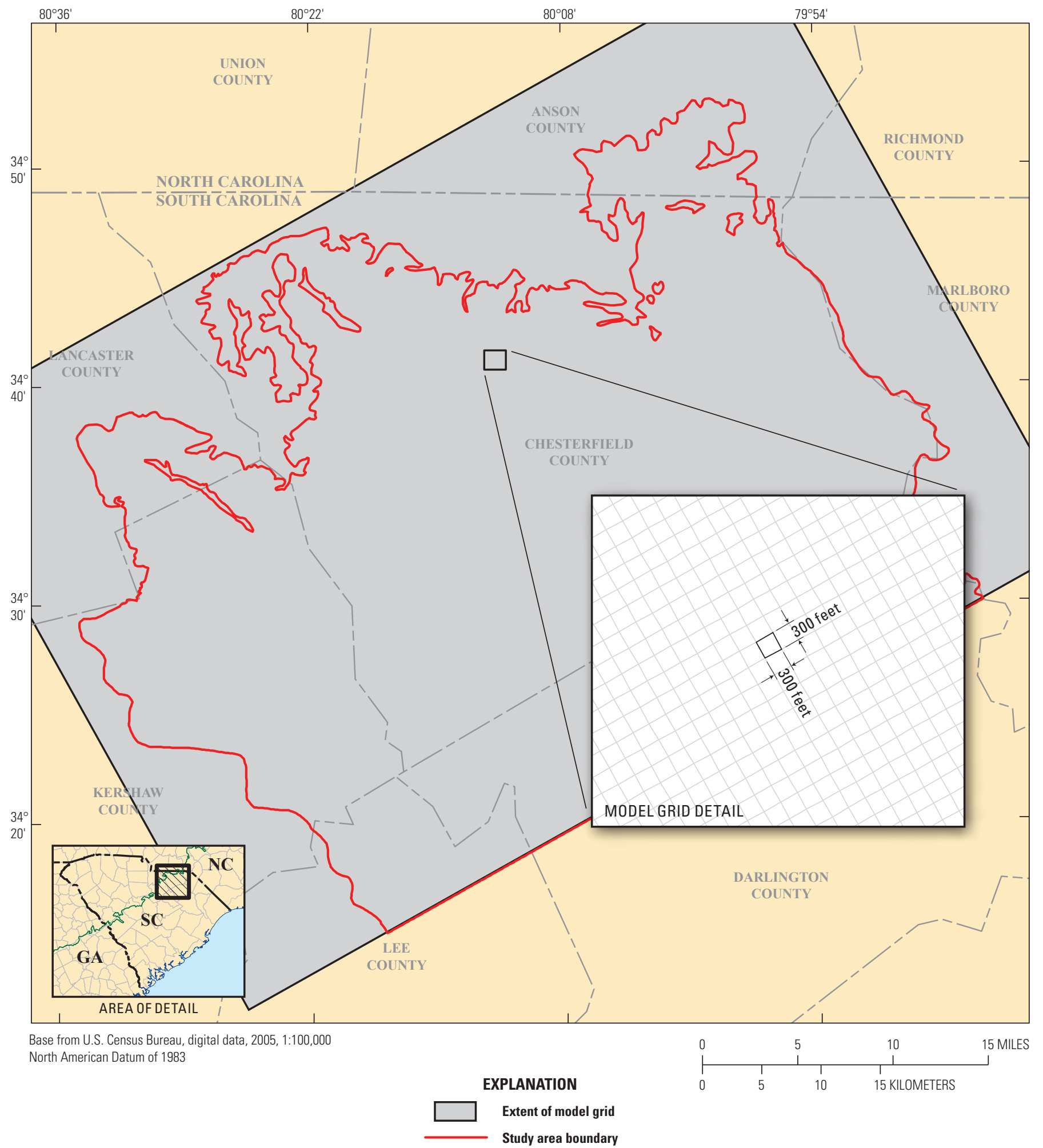

Figure 14. Chesterfield County area groundwater-flow model grid with a uniform 300-foot by 300-foot model cell size. 


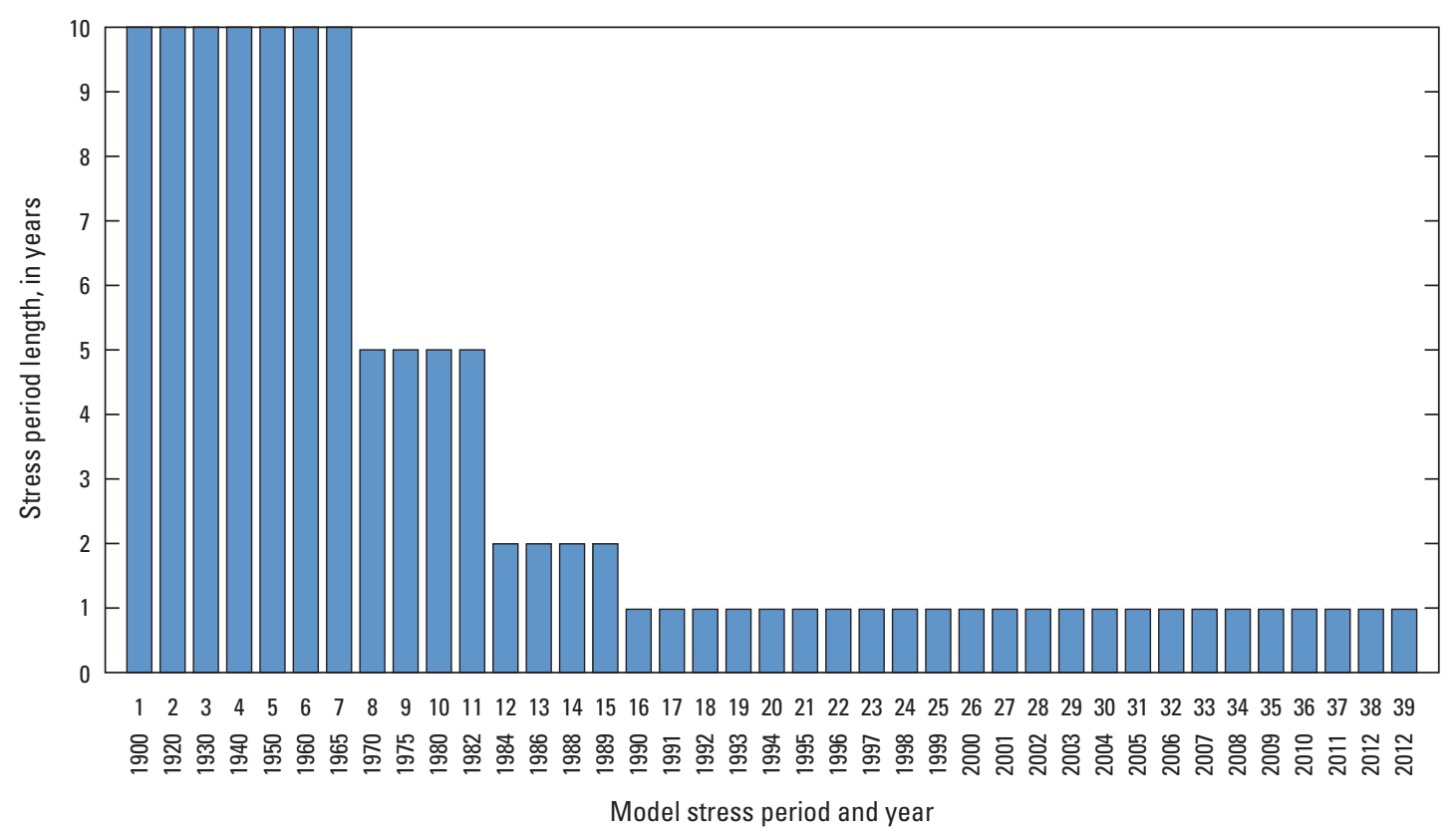

Figure 15. Groundwater-flow model stress periods, 1900 to 2012, Chesterfield County area.

Figure 16. Conceptual model of the aquifers and confining units of the Atlantic Coastal Plain in the Chesterfield County area (modified from Healy and others, 2007).

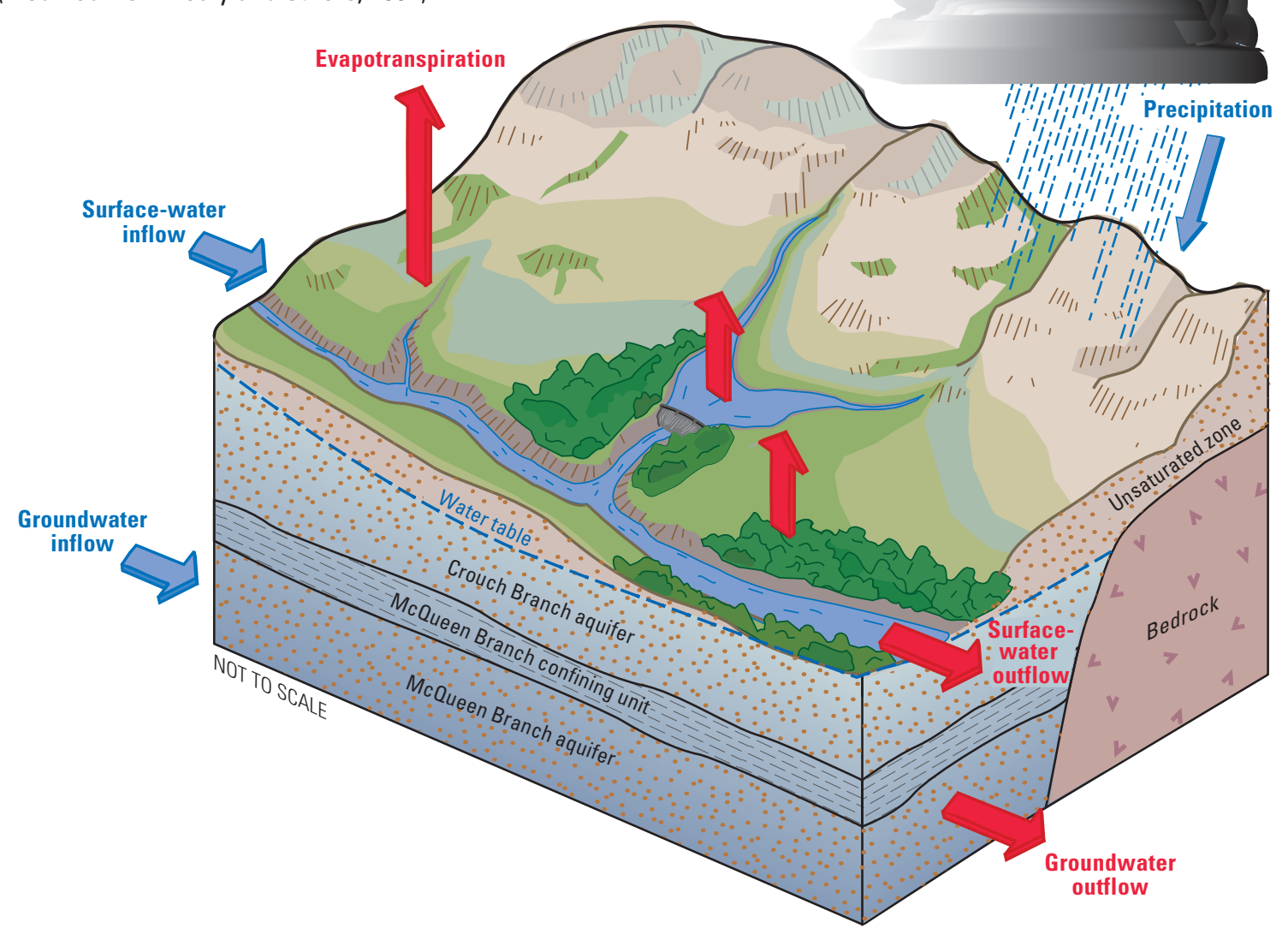




\section{Boundary Conditions and Model Stresses}

Several boundary conditions are used in the groundwaterflow model of the study area, including no-flow and timevarying specified-head boundaries (Harbaugh and others, 2000). No-flow boundaries are used along the Fall Line, the topographic divide between the Little Lynches River and Wateree River Basins, and the geologic boundary between the ACP sediments and the Piedmont crystalline rocks at the base of the model (fig. 6).

The Time-Variant Specified-Head (TVSH) MODFLOW package is used to simulate the model boundary at the southeast edge of the model (fig. 1) and simulates groundwater flow from the model area to downdip parts, outside of the model, to the Crouch Branch and McQueen Branch aquifers. The time-varying specified heads used in this boundary are derived from potentiometric-surface maps of the Middendorf aquifer (equivalent to the Crouch Branch and McQueen Branch aquifers) over time (Aucott and Speiran, 1985c; Hockensmith, 2008). The TVSH package is used to simulate the model boundary that is represented by the Pee Dee River below the Fall Line and is based on the altitude of the river determined from Digital Elevation Model (DEM) data described above.

\section{Recharge}

Recharge to the groundwater-flow model is simulated with the MODFLOW Recharge package (Harbaugh and others, 2000). The recharge package is used to simulate a specified flux (precipitation, in this case) distributed to the highest active model cell across the horizontal extent of the model and specified in units of length/time. Within MODFLOW, these rates are multiplied by the horizontal area of the cells to which they are applied to calculate the volumetric flux rates. For the Chesterfield County model, a net recharge rate was used, which is assumed to be the precipitation minus the estimated evapotranspiration rate and overland flow for the study area. Evapotranspiration and overland flow are not simulated in the model. All net recharge in the model is applied to model layer 1 representing the Crouch Branch aquifer. In the model, two recharge zones are used to represent upland areas and wetland areas. Upland areas cover about 85 percent of the study area (fig. 17). Most of the larger streams and rivers have extensive wetland areas that border the surface-water corridors. These wetland areas are conceptualized as groundwater discharge areas, so a different net recharge rate is applied to the wetland areas compared to the upland areas.

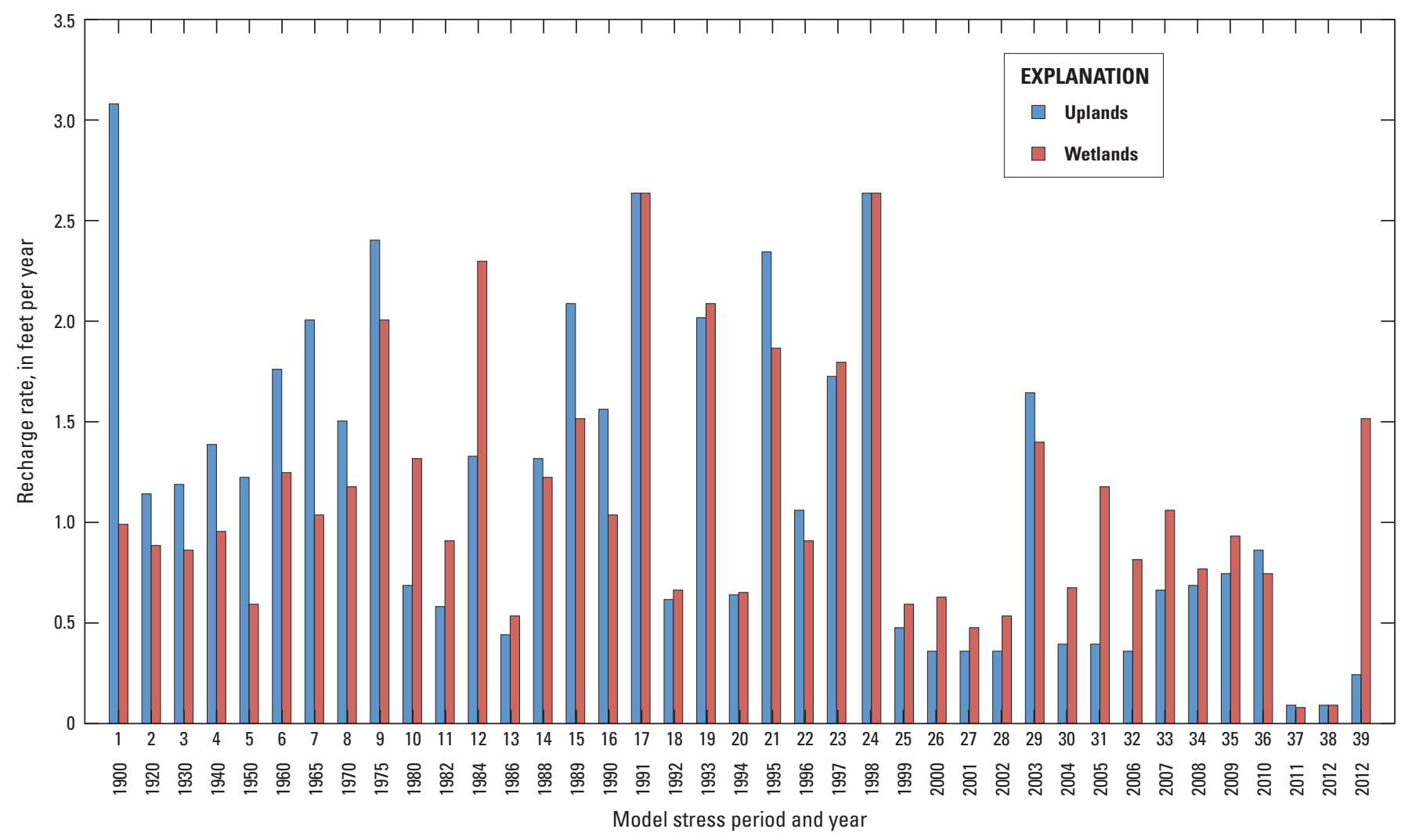

Figure 17. Simulated net recharge rates (1900-2012) for the wetlands and uplands areas, Chesterfield County area. 
Wetland delineations from the U.S. Fish and Wildlife Service National Wetlands Inventory (U.S. Fish and Wildlife Service, 2009) were obtained and used to discretize the study area into uplands and wetlands areas. The original National Wetlands Inventory data were modified by hand to simplify and create polygons that could be used for input into the graphical user interface used to construct the MODFLOW input files (fig. 18). This simplification process removed small, isolated wetland areas and preserved the wetland areas along the streams and rivers. Most of these isolated wetlands are not connected to the groundwater-flow system in the study area due to the depth to groundwater (as much as $200 \mathrm{ft}$ ).

During the model calibration process, the net recharge rates are allowed to vary over time to attempt to match the observed groundwater levels and more importantly, the observed base-flow measurements from streams in the study area. These calibrated, net recharge rates varied from 0.08 to 3.07 feet per year ( $\mathrm{ft} / \mathrm{yr}$ ) over the simulation period of 1900 to 2012. There are several periods of high precipitation $(1929,1950,1970,1990$, and 1997) and several periods of low precipitation (1975-80, 1984, 1998-2001, and 2005-2012) (fig. 4). The lowest rates of precipitation correspond to droughts during 1998-2002 and 2009-2011 (fig. 4) when stream base flows were at or near period-of-record lows. The wetland and upland recharge rates are not substantially different, and both show the same overall trends (fig. 17). The mean net recharge rates are $1.16 \mathrm{ft} / \mathrm{yr}$ for the uplands and $1.18 \mathrm{ft} / \mathrm{yr}$ for the wetlands, and the standard deviations are 0.80 and 0.71 for the uplands and wetlands, respectively. The lowest net recharge rate during the drought years $(0.08 \mathrm{ft} / \mathrm{yr})$ is an extremely low net recharge rate, but conceptually the evapotranspiration demand for the study area is met before recharged precipitation moves into the groundwater-flow system. During the drought years, the evapotranspiration demand is barely met, with little water left for net recharge and subsequent discharge to the streams and springs in the study area. These low recharge rates are reflected in the low stream base flows during the drought periods.

\section{Wells}

Potable-water supply, irrigation, industrial, and mine dewatering wells located in the study area are simulated with two MODFLOW packages: (1) the WEL package (Harbaugh and others, 2000) and the Multi-Node Well 1 (MNW1) package (Halford and Hanson, 2002). Two different MODFLOW packages are used to simulate the various wells because of the presence or absence of well construction documentation. The wells with complete documentation on screen zones and depths were simulated with the MNW1 package. The MNW1 package allows for the simulation of wells that are open to multiple aquifers due to the presence of long screened intervals. Many of the potable-water supply wells in the Chesterfield County study area have long screened intervals that extend across the Crouch Branch and McQueen Branch aquifers. The rest of the wells that did not have complete documentation on screen settings and depths were simulated with the WEL package and were manually assigned to a specific aquifer based on the available information such as well depth.

Water-use data for all of the wells simulated in the study area were obtained from SCDHEC (A. Butler, South Carolina Department of Health and Environmental Control, Water-Use Data for Chesterfield, Darlington, Kershaw and Lee Counties, 1980-2010, written commun., 2011). These data begin in 1980, when the water-use program started in South Carolina. Groundwater users that withdraw more than 3 million gallons in any month are required to report their usage (South Carolina Department of Health and Environmental Control, 2006). Historical groundwater-use data, prior to 1980, for Hartsville, S.C., were collected from records maintained by the city of Hartsville and incorporated into the groundwater-flow model (Aucott and Sperian, 1996).

\section{Groundwater Discharge to Surface-Water Bodies}

Where the water table intersects the land surface in the study area, groundwater discharges to surface water, and the stream's flow increases downstream. This concept is demonstrated in several places in the study area, primarily in the Black Creek Basin, where three gages provide streamflow measurements (fig. 19). The average annual flows for the periods of record at these gages (from upstream to downstream) are 41 cubic feet per second $\left(\mathrm{ft}^{3} / \mathrm{s}\right)$ at 02130840 (Black Creek below Chesterfield, S.C.), $109 \mathrm{ft}^{3} / \mathrm{s}$ at 02130900 (Black Creek near McBee, S.C.), and $156 \mathrm{ft}^{3} / \mathrm{s}$ at 02130910 (Black Creek near Hartsville, S.C.). These mean annual flows indicate a strongly gaining stream with large volumes of groundwater discharged to Black Creek as it flows downstream.

Flow in several other streams was measured at upstream and downstream locations as part of this investigation. These were not sites where continuous streamflow was recorded but where individual measurements of flow were taken to collect data for model calibration purposes. Streamflow on Swift Creek was measured at three sites, two upstream (North Prong of Swift Creek at Swift Creek Road and South Prong Swift Creek at Swift Creek Road) and one downstream at Swift Creek and Highway 151 (fig. 19). The two upstream streamflow measurements were $3.2 \mathrm{ft}^{3} / \mathrm{s}$ at North Prong of Swift Creek at Swift Creek Road and $0.1 \mathrm{ft}^{3} / \mathrm{s}$ at South Prong Swift Creek at Swift Creek Road. Streamflow at Swift Creek at Highway 151, the site furthest downstream, was $7.3 \mathrm{ft}^{3} / \mathrm{s}$. Streamflow measurements in Big Sandy Creek and Little Rocky Creek show the same pattern of increasing flows downstream.

Altogether, base flows were estimated from streamflow data from 44 sites (fig. 13), and these estimates were used for model calibration purposes. The data are from several sources, including active USGS streamgages (3 sites), inactive USGS streamgages ( 2 sites), several low-flow studies (12 sites), and discrete streamflow measurements done as part of this study (24 sites) (table 1). The discrete streamflow measurements were made with a hand-held acoustic Doppler current meter. These types of meters are based on the Doppler principle. The velocity of the moving water is measured using the transmitted and received signals from sound pulses reflecting off particles in the moving water column (Turnipseed and Sauer, 2010). 


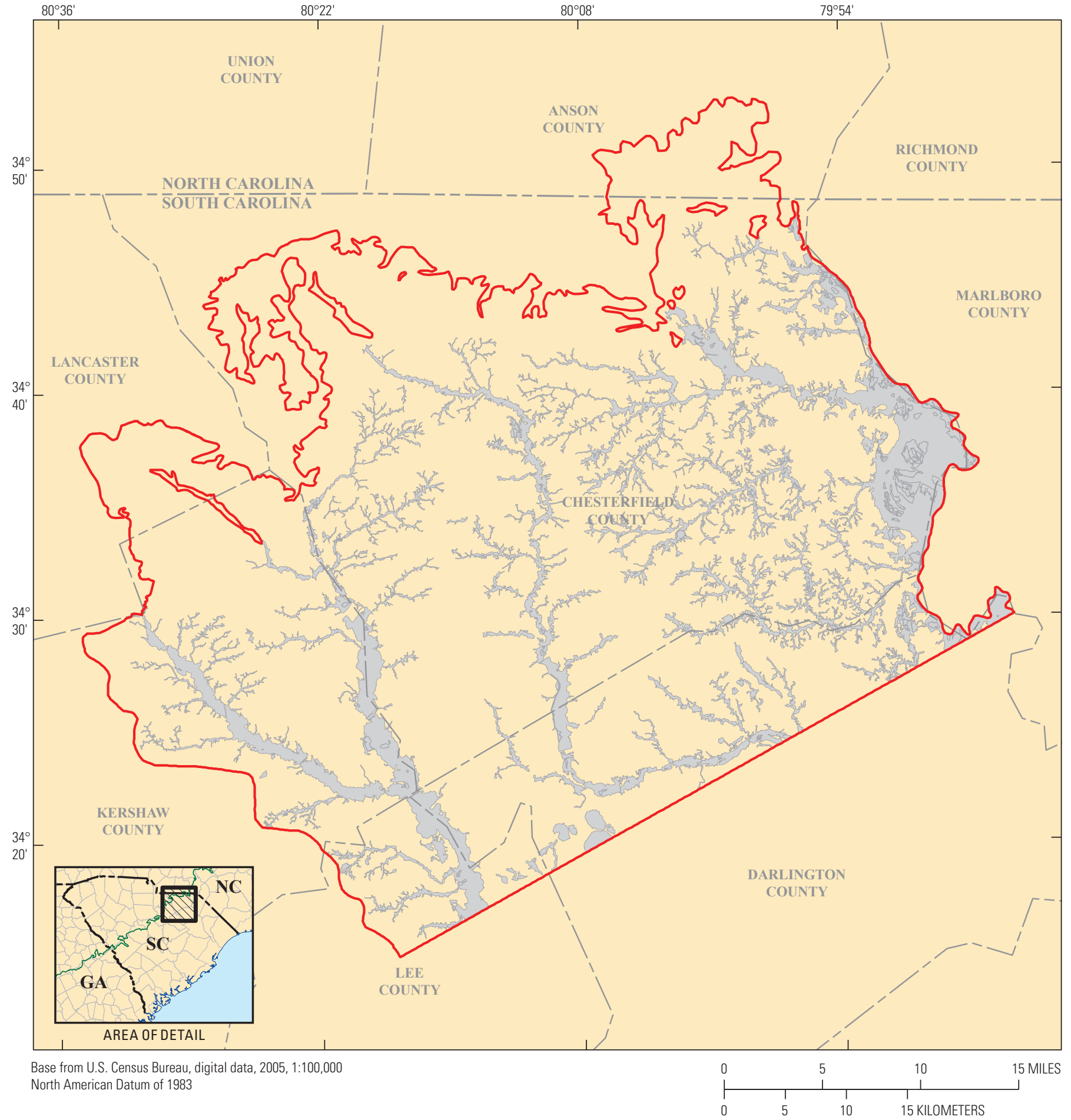

EXPLANATION

National Wetlands Inventory area

(U.S. Fish and Wildlife Service, 2009)

Study area boundary

Figure 18. National Wetlands Inventory areas within the Chesterfield County area. 


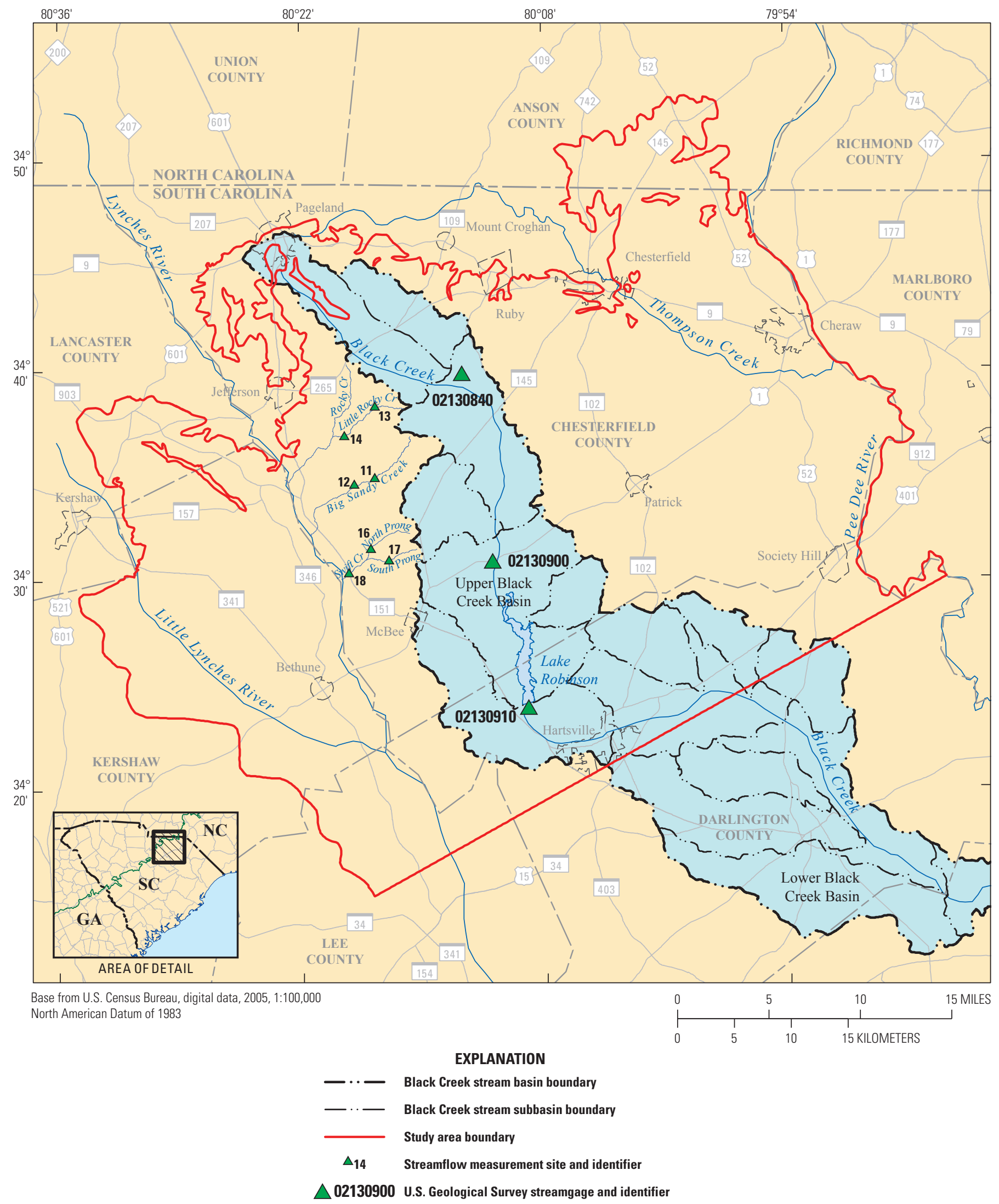

Figure 19. Locations of Black Creek Basin streamgages and locations of selected streamflow measurement sites on Swift Creek, Big Sandy Creek, and Little Rocky Creek in the Chesterfield County area. 


\section{Model Calibration}

The Chesterfield County groundwater-flow model was calibrated to groundwater-level and stream base-flow conditions from 1900 to 2012 by using 944 parameters and 39 stress periods (fig. 15). The model was calibrated to conditions from the 1940s to 2012 when discrete groundwater levels were available from individual wells. Streamflow data for the period 1941 to 2012 were also used in the model calibration. Model input parameters used in the model calibration process include horizontal hydraulic conductivity, horizontal anisotropy, specific storage, drain conductance, and net recharge. If data were available for these inputs, an attempt was made to incorporate the data into the calibration process. Examples are hydraulic conductivity values derived from aquifer tests (Newcome, 2004b) or trends in recharge rates.

The model was calibrated with an automated parameterestimation approach by using the computer program PEST (Doherty, 2008a,b), and the model used regularized inversion and pilot points (de Marsily and others, 1984; LaVenue and Pickens, 1992; Doherty, 2003; Doherty and Hunt, 2010). With PEST, horizontal hydraulic conductivity values were estimated at "pilot points" distributed throughout the model; the estimated values then were interpolated to each active model grid cell (fig. 14). The pilot points were spatially distributed to match well locations where hydraulic conductivity data were available; in areas where no hydraulic conductivity data were available, the pilot points were distributed in an approximately regularly spaced distribution. The hydraulic conductivities at the pilot points were estimated in such a way that the weighted sum-of-squares differences (objective function) between simulated and observed water levels and simulated and measured stream base flows were minimized.

The use of pilot points for parameterization resulted in many more parameters than would have resulted by using zones of uniform parameter values. Regularized inversion was used through PEST to numerically stabilize the overparameterized inverse problem (Doherty, 2003). In addition, by using regularization in the parameter-estimation process, a large number of parameters could be estimated, allowing for locations where heterogeneity likely exists and was expected to be identified through the calibration process.
Published horizontal hydraulic conductivity values from the McQueen Branch aquifer within the study area were used as initial values for the hydraulic conductivity pilot points (Aucott and Newcome, 1986; Newcome, 1993, 2000, $2004 b)$. These values were allowed to vary within reasonable limits during model calibration to obtain the best fit to the observation data. No measurements of hydraulic conductivity were available for the McQueen Branch confining unit or the Crouch Branch aquifer within the study area.

Calibrated hydraulic conductivity values for the aquifers ranged from 2 to $112 \mathrm{ft} / \mathrm{d}$; the highest mean value $(44 \mathrm{ft} / \mathrm{d})$ occurred in layer 3, the McQueen Branch aquifer, and the lowest mean value $(36 \mathrm{ft} / \mathrm{d})$ occurred in layer 1 , the Crouch Branch aquifer (table 2; figs. 20 and 21). Calibrated hydraulic conductivity values for layer 2, the McQueen Branch confining unit, ranged from $1.4 \times 10^{-5} \mathrm{ft} / \mathrm{d}$ to $1 \mathrm{ft} / \mathrm{d}$ (table 2 ; fig. 22).

Calibrated specific storage values were $2.6 \times 10^{-2} \mathrm{ft}^{-1}$ for the Crouch Branch aquifer, 7.8 $\times 10^{-4} \mathrm{ft}^{-1}$ for the McQueen Branch confining unit, and $1.95 \times 10^{-4} \mathrm{ft}^{-1}$ for the McQueen Branch aquifer. The calibrated specific storage value used for the Crouch Branch aquifer $\left(2.6 \times 10^{-2}\right)$ is high for a confined aquifer, however, the unconfined Crouch Branch aquifer is simulated as a confined aquifer to minimize convergence problems inherent to MODFLOW (Kuniansky and Danskin, 2003). This large specific storage value when multiplied by the aquifer thickness provides a storage property close to a specific yield value. Calibrated vertical anisotropies for both aquifers and the confining unit were 3.0.

Pilot points were used to smoothly vary the horizontal anisotropy in the Crouch Branch and McQueen Branch aquifers while a single value was used for the McQueen Branch confining unit. Calibrated horizontal anisotropy ranged from 1.0 to 4.1 (dimensionless) in the Crouch Branch aquifer, was 3.0 in the McQueen Branch confining unit, and ranged from 1.0 to 5.2 in the McQueen Branch aquifer.

The groundwater-flow model was calibrated by using field data that included water levels from 239 wells and streamflow measurements from 44 locations distributed within the study area, some of which included 2 or more measurements on the same stream at upstream and downstream locations (fig. 13). These data were incorporated into the parameter estimation process, and the model inputs described above were

Table 2. Summary statistics for the calibrated horizontal hydraulic conductivities in the Chesterfield County area.

[ft/d, feet per day]

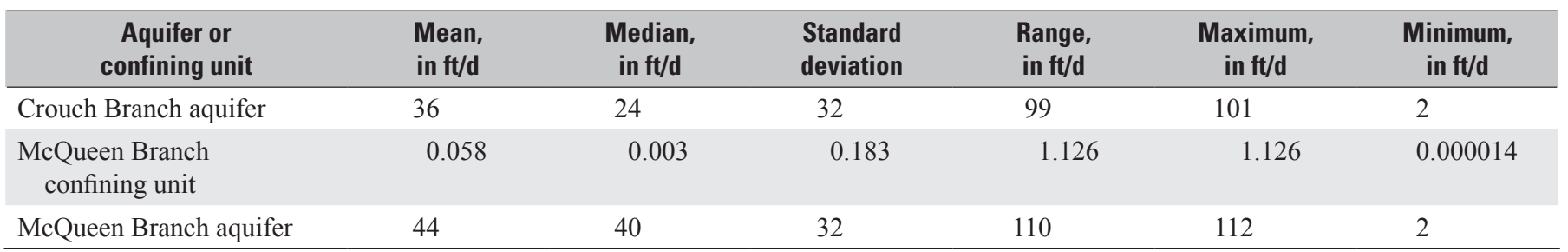




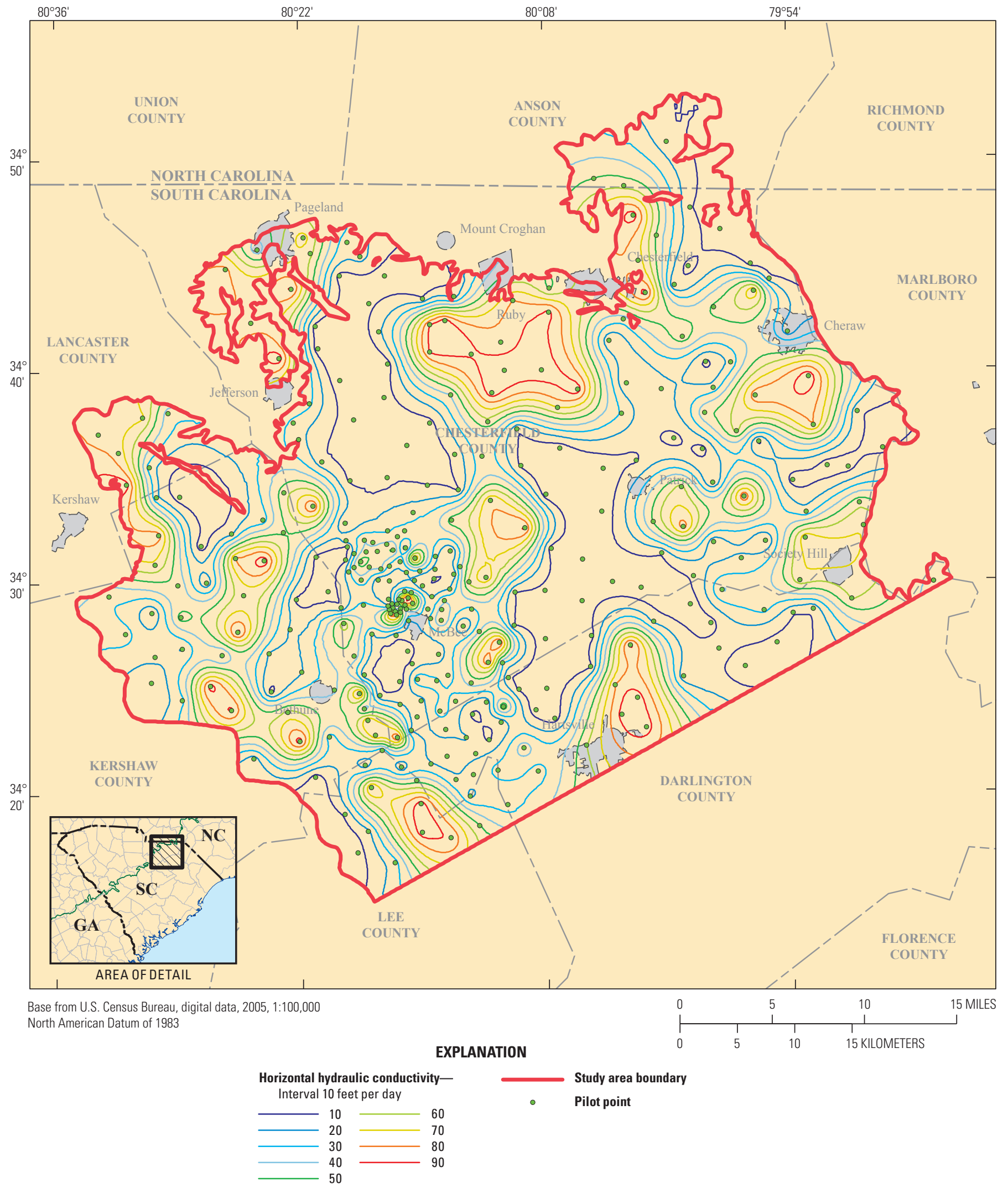

Figure 20. Calibrated horizontal hydraulic conductivities for the Crouch Branch aquifer in the Chesterfield County area. 


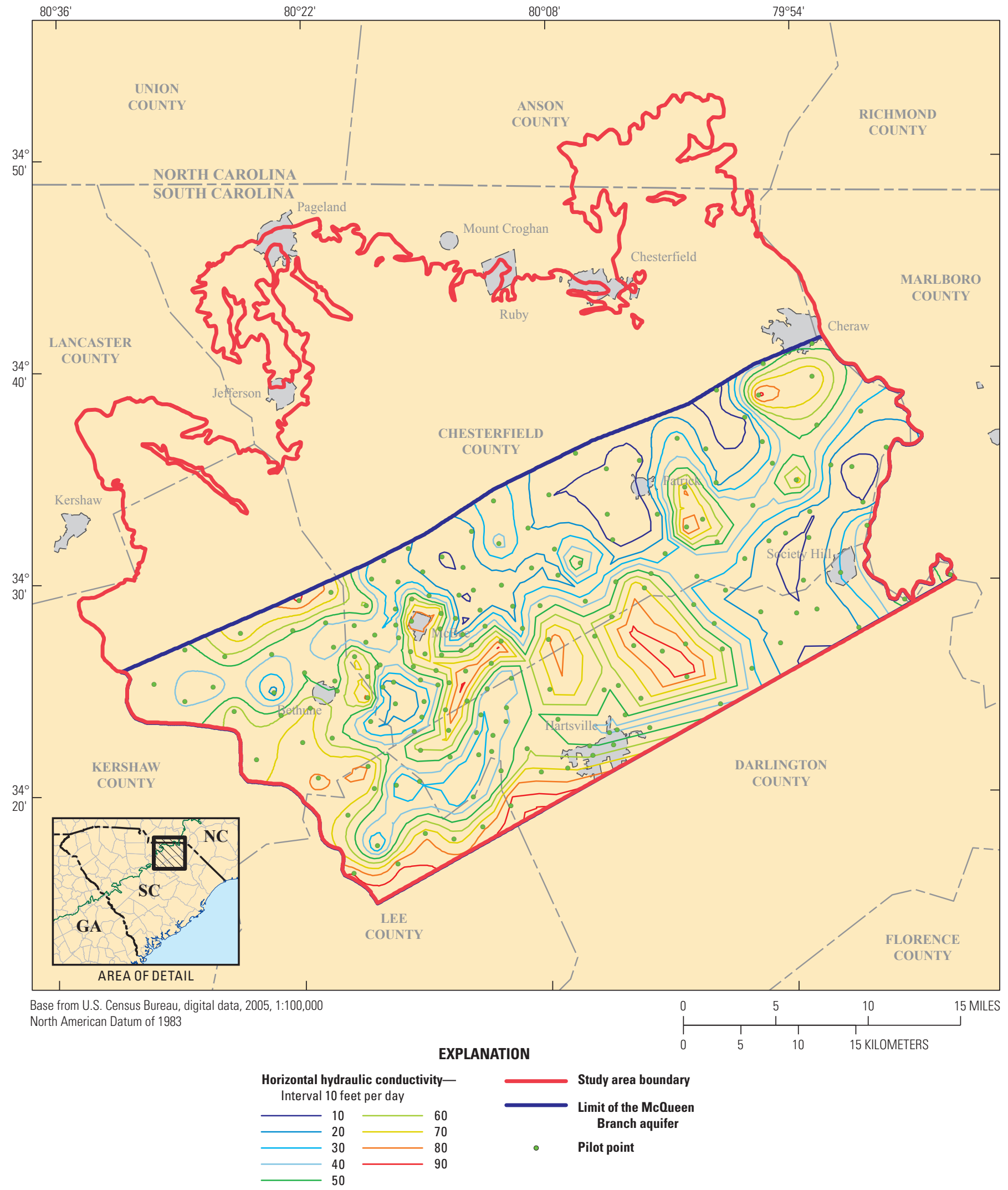

Figure 21. Calibrated horizontal hydraulic conductivities for the McQueen Branch aquifer in the Chesterfield County area. 


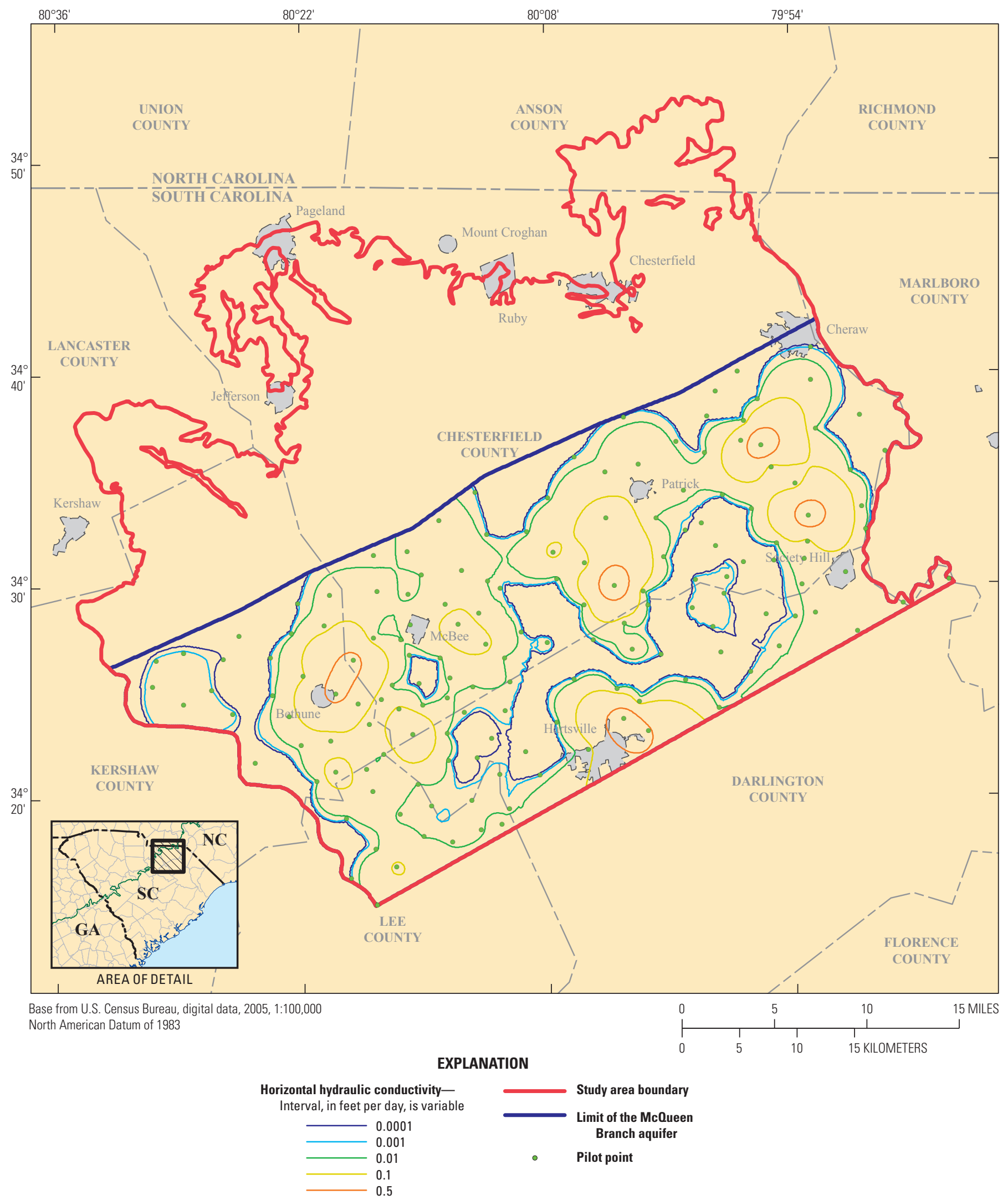

Figure 22. Calibrated horizontal hydraulic conductivities for the McQueen Branch confining unit in the Chesterfield County area. 
adjusted by using the PEST program to minimize the difference between the observed and simulated values. Water levels from 154 wells open to the Crouch Branch aquifer were used in the calibration process. These wells ranged from domestic wells with a single water-level measurement, to test wells drilled specifically for the study, to wells where continuous groundwater-level monitoring equipment was installed and groundwater levels were recorded for about 5 years. Groundwater levels from 85 wells screened in the McQueen Branch aquifer were used; most of these wells are production wells of various types, including public supply, irrigation, and industrial supply. The target calibration criteria for the simulated groundwater-level measurements were $\pm 10 \mathrm{ft}$ of the observed value. A reasonable fit to water-level altitude is achieved if the majority of weighted residuals (observed minus simulated heads) are less than two times the accuracy of the data to account for both general altitude accuracy and additional error in spatial location or variation during a model stress period. Thus the calibration criteria for weighted head residuals are that the majority should be less than $10 \mathrm{ft}$ in the study area to consider the model well calibrated. It is also desirable that the residuals be normally distributed and not have spatial bias. A spatial bias occurs when all residuals are positive (simulated heads are lower than observed heads) in one area and negative (simulated heads are higher than observed heads) in another area. Normally distributed residuals with no spatial bias would be both positive and negative in a somewhat random pattern in all areas, resulting in the mean of the residuals equaling zero or close to zero - another desirable characteristic of a good fit to the water-level data (Fine and Kuniansky, 2014).

For the Crouch Branch aquifer groundwater levels (154 total), 22 percent, or 35 out of 154, were outside of the \pm 10 -ft calibration target with 26 measurements $+10 \mathrm{ft}$ and 9 measurements outside of $-10 \mathrm{ft}$. For the McQueen Branch aquifer groundwater levels ( 85 total), 22 percent, or 19 out of 85 , were outside of the \pm 10 -ft calibration target with 14 measurements $+10 \mathrm{ft}$ and 5 measurements outside of $-10 \mathrm{ft}$.

During the model calibration process, the groundwater levels and flows are assigned weights, which are a measure of the expected precision of the measurement and the amount of information they are likely to contain regarding the simulated model parameters (Doherty and Hunt, 2010). These weights can be assigned by a rigorous mathematical process in an attempt to account for the precision of measurement, but as Doherty and Hunt (2010) suggest, this methodology can lead to problems such as unbalanced regressions with some observations dominating or not accounting for the importance of some types of measurements. The weighting strategy employed was to promote equal visibility of the two measurement types (groundwater levels and flows) during the parameter estimation process. The groundwater levels were all equally weighted, and the weighting of the flow measurements was adjusted to represent about 20 percent of the objective function.

The groundwater-flow model produced an acceptable fit to the observed groundwater levels from the 239 wells. The 154 observed groundwater levels for the Crouch Branch aquifer ranged from a low of $75 \mathrm{ft}$ above NAVD 88 to a high of $555 \mathrm{ft}$ above NAVD 88 (table 3; figs. 23 and 24). The mean residual (difference between the observed and simulated groundwater levels) was $2.7 \mathrm{ft}$ with a root mean square error (RMSE) of $9.2 \mathrm{ft}$. The normalized standard deviation (the weighted residuals divided by the range of the Crouch Branch aquifer water levels) was 0.02 (dimensionless). This dimensionless statistic is useful because it takes into account the range in water-level data used in the calibration process. Optimally, the normalized standard deviation will be less than 0.1 , meaning that the majority of the residuals are less that 10 percent of the range in observations (Kuniansky and others, 2004; Fine and Kuniansky, 2014). The 2012 simulated potentiometric surface of the Crouch Branch aquifer (fig. 25) reflects the influence of groundwater to surface-water discharges. The larger surfacewater drainages, Little Lynches and Lynches Rivers and Black and Thompson Creeks, (fig. 6) influence the shape of the potentiometric surface and show the gaining nature of these streams. The relatively small model grid cell size of $300 \mathrm{ft}$ by $300 \mathrm{ft}$ (fig. 14) allows small features of the potentiometric surface, such as Swift Creek (fig. 19), to be seen.

Table 3. Statistics for model calibration for the Chesterfield County area.

[ft, foot]

\begin{tabular}{lcc}
\hline \multicolumn{1}{c}{ Statistic } & $\begin{array}{c}\text { Crouch Branch } \\
\text { aquifer }\end{array}$ & $\begin{array}{c}\text { McQueen Branch } \\
\text { aquifer }\end{array}$ \\
\hline Number of observations & 154 & 85 \\
\hline Range of observations (ft) & 480 & 281 \\
\hline $\begin{array}{l}\text { Minimum residual (ft) } \\
\text { Maximum residual (ft) }\end{array}$ & -42 & -26 \\
\hline $\begin{array}{l}\text { Mean residual (ft) } \\
\text { Standard deviation of } \\
\text { residuals (ft) }\end{array}$ & 1.4 & 20 \\
\hline $\begin{array}{l}\text { Root mean square error of } \\
\text { residuals (ft) }\end{array}$ & 10.1 & 0.5 \\
\hline $\begin{array}{c}\text { Percentage of values within } \\
\text { 10-ft error range }\end{array}$ & 78 & 9.5 \\
\hline $\begin{array}{c}\text { Normalized standard } \\
\text { deviation }\end{array}$ & 0.02 & 78 \\
\hline
\end{tabular}

${ }^{1}$ Normalized standard deviation is the standard deviation of residuals divided by the range of observations (Kuniansky and others, 2004; Fine and Kuniansky, 2014). 


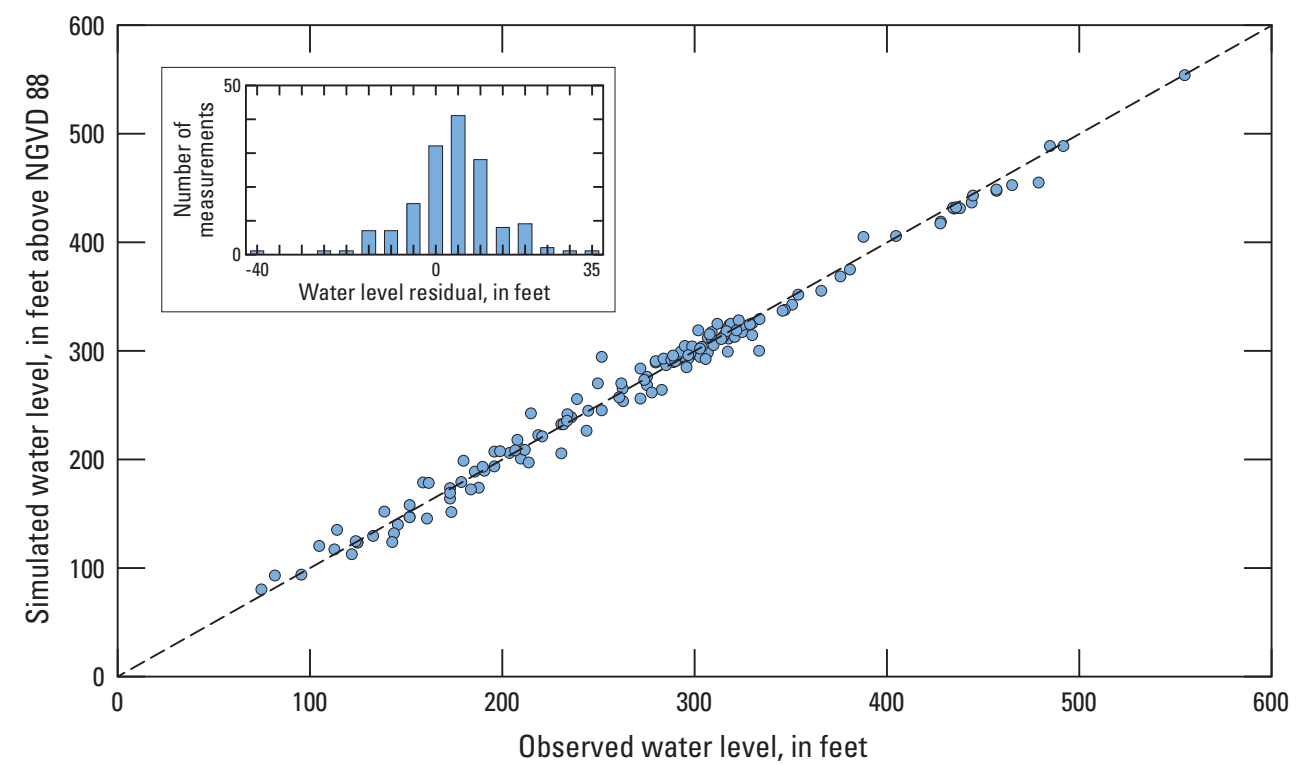

Figure 23. Observed and simulated groundwater levels (1940-2012) for the Crouch Branch aquifer in the Chesterfield County area.

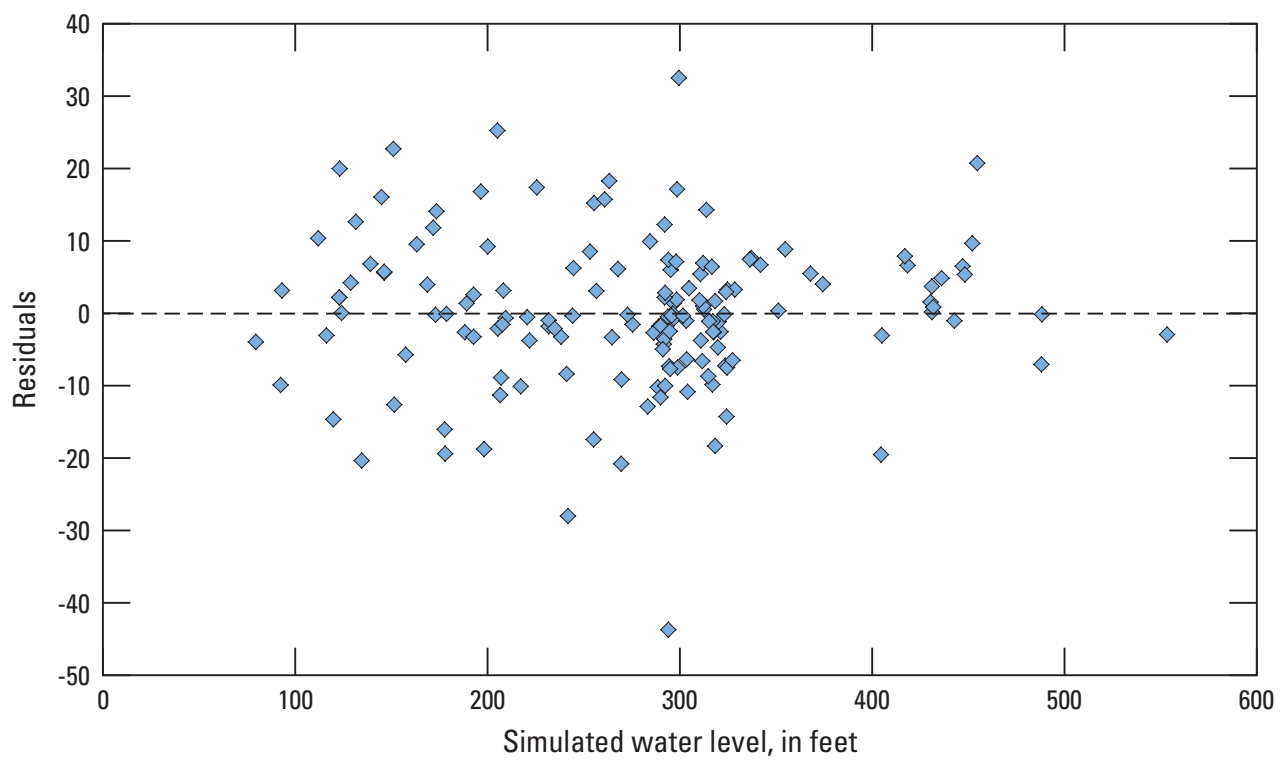

Figure 24. Water-level residuals and simulated water levels (1940-2012) for the Crouch Branch aquifer in the Chesterfield County area. 


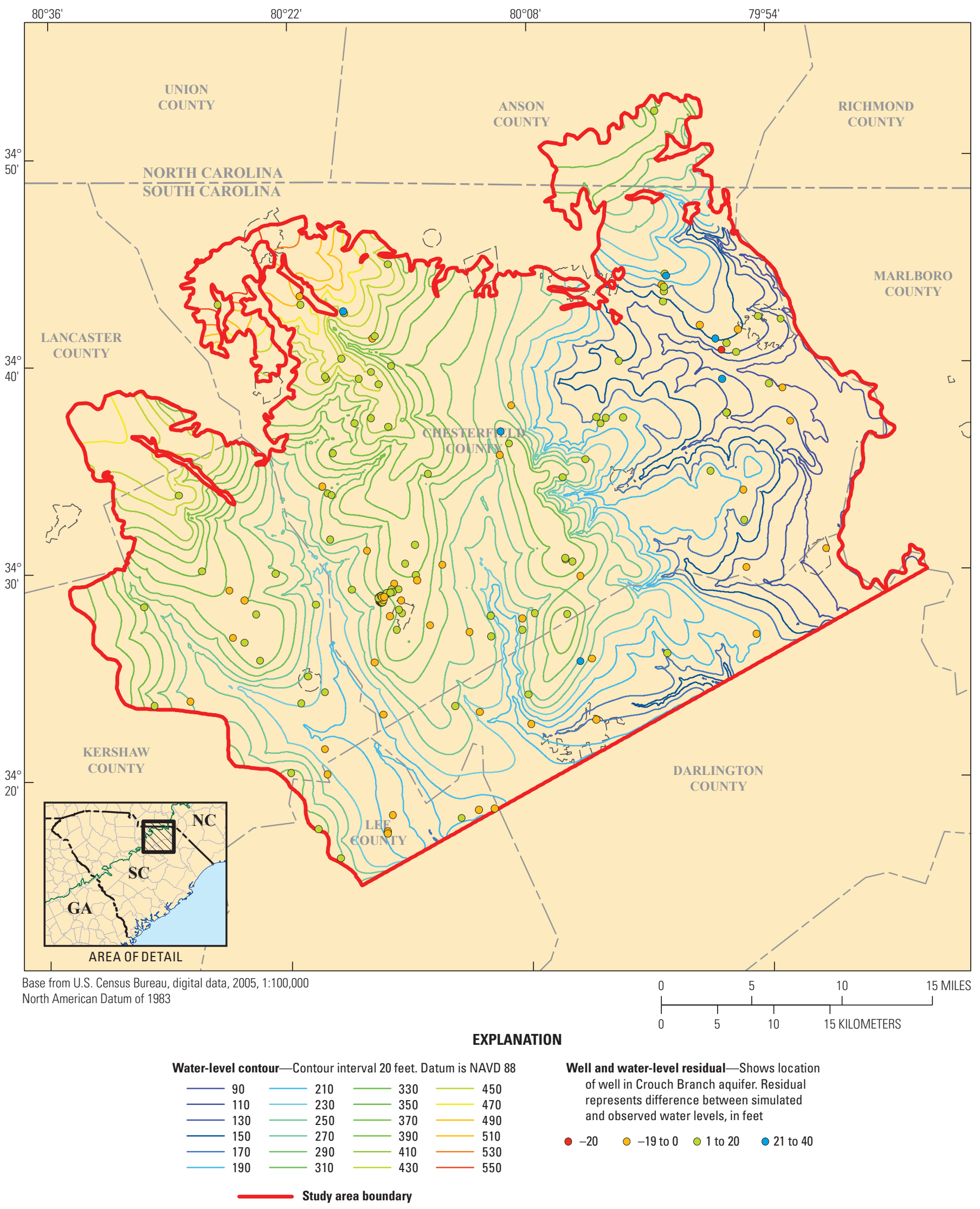

Figure 25. Simulated water levels and water-level residuals for the Crouch Branch aquifer (2012) in the Chesterfield County area. 
The model also produced an acceptable fit for the 85 observed groundwater levels from the McQueen Branch aquifer (table 3; figs. 26 and 27). The observed groundwater levels ranged from a low of $78 \mathrm{ft}$ above NAVD 88 to a high of $351 \mathrm{ft}$ above NAVD 88 . The mean residual was $1.5 \mathrm{ft}$ with an RMSE of $8.6 \mathrm{ft}$. The normalized standard deviation for the McQueen Branch aquifer water levels used in the calibration process was 0.03 (dimensionless). The 2012 simulated potentiometric surface of the McQueen Branch aquifer (fig. 28) is influenced by the larger surface-water features in the study area such as the Pee Dee, Little Lynches, and Lynches Rivers and Black Creek (fig. 6). For the most part, smaller surfacewater features do not influence groundwater levels in the McQueen Branch aquifer.

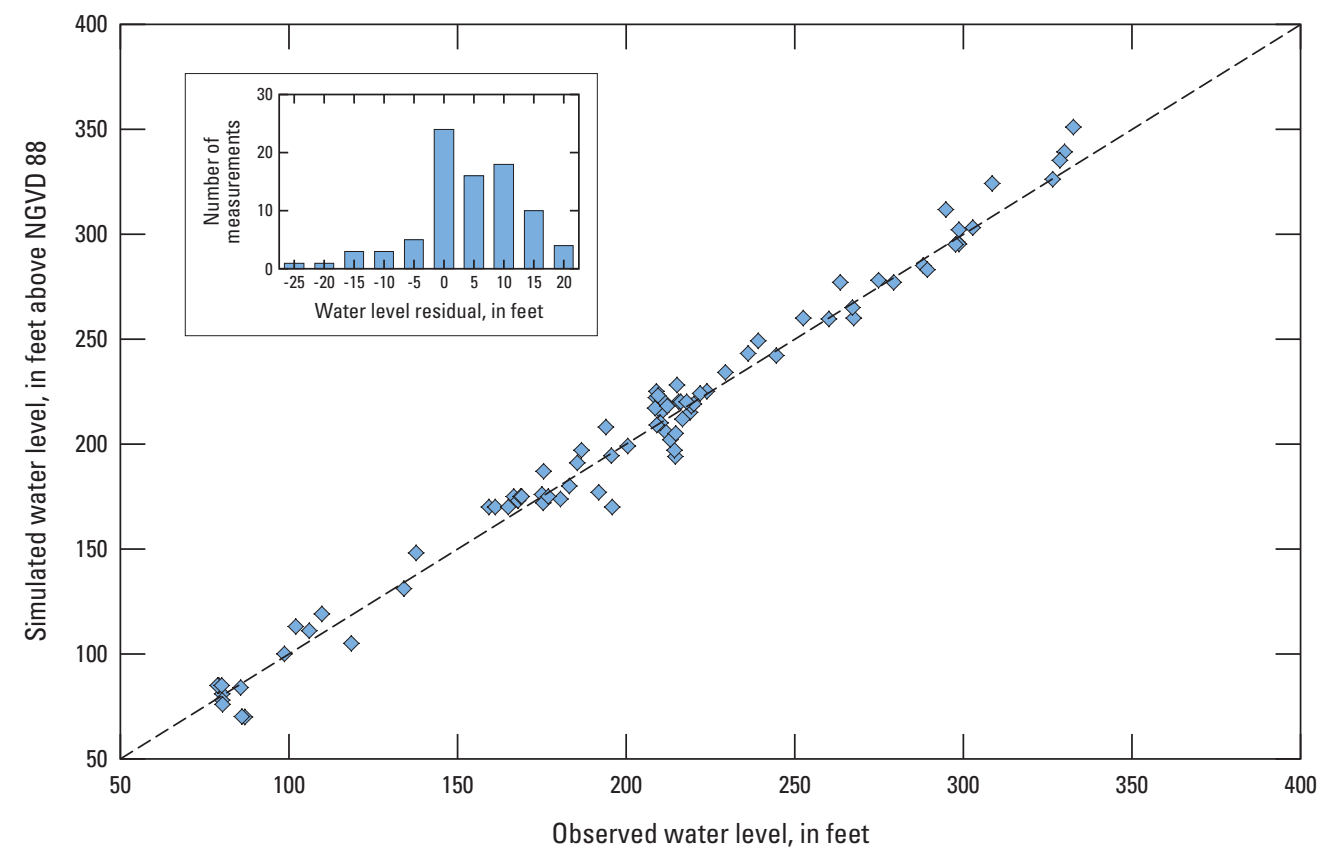

Figure 26. Observed and simulated groundwater levels (1940-2012) for the McQueen Branch aquifer in the Chesterfield County area.

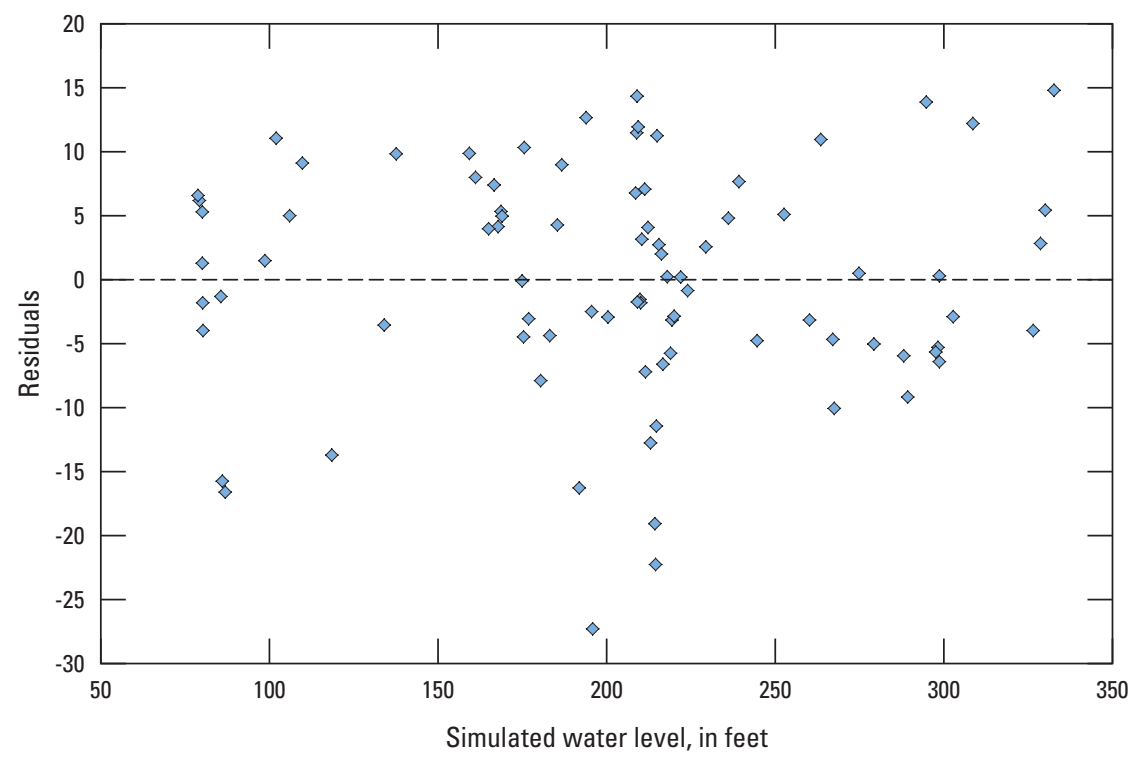

Figure 27. Water-level residuals and simulated water levels (1940-2012) for the McQueen Branch aquifer in the Chesterfield County area. 


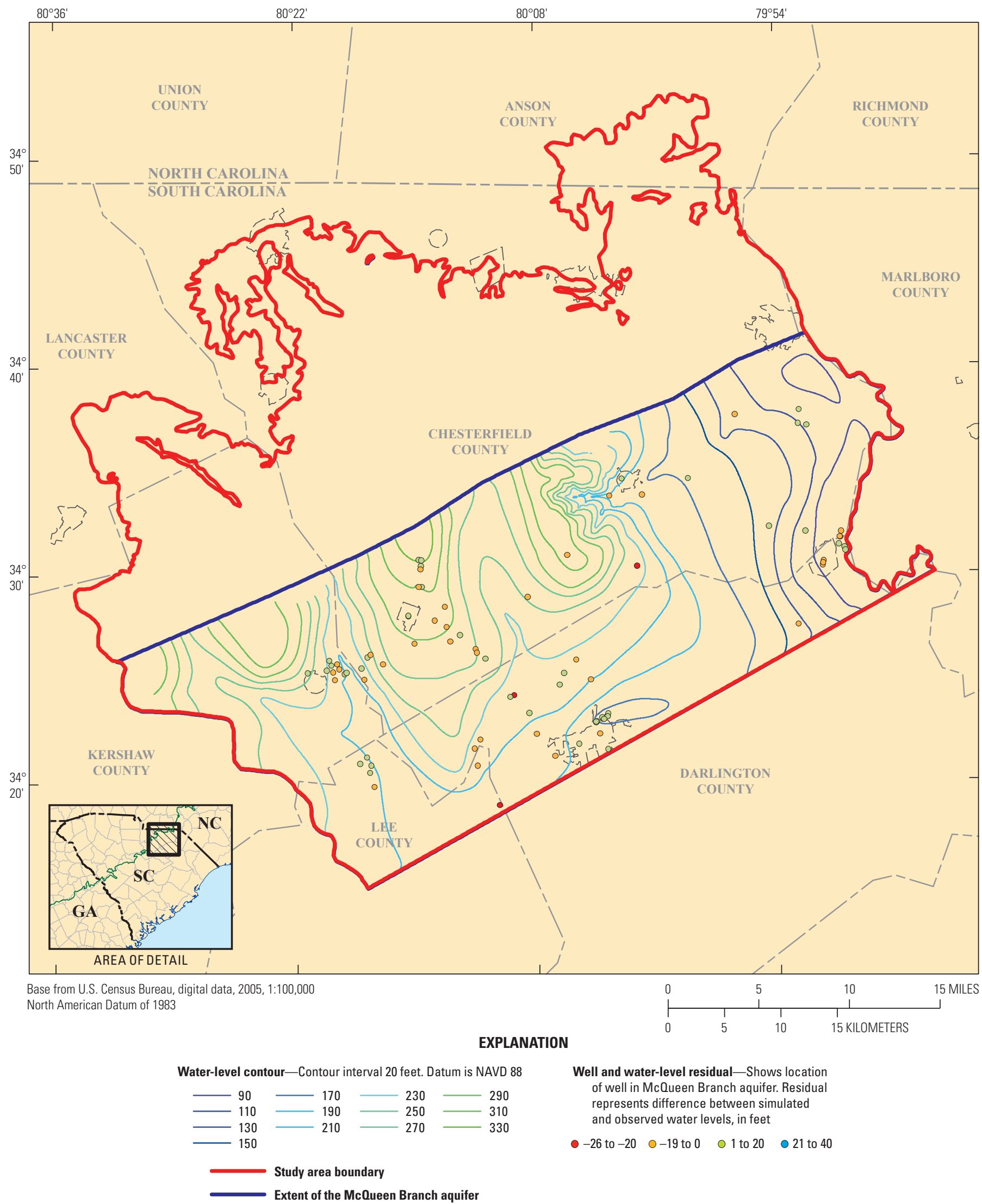

Figure 28. Simulated potentiometric surface of the McQueen Branch aquifer (2012) in the Chesterfield County area. 
Groundwater levels collected continuously at seven recording wells as part of this study were included in the model calibration process, and the observed groundwater levels were compared to simulated groundwater levels. The recording wells produce a detailed record of changes in groundwater levels due to nearby seasonal pumping, rainfall events, and barometric pressure changes, but the model simulates groundwater levels over time intervals of a minimum of 1 year and cannot simulate all of the local and short-term stresses that are recorded in groundwater levels collected from the seven wells. To account for this, a mean annual groundwater level is calculated for each recording well's period of record and is compared to the simulated groundwater levels.

Wells CTF-222 (171 ft deep) and CTF-221 (260 ft deep) are paired Crouch Branch and McQueen Branch aquifer wells located at the same site southeast of McBee, S.C. (fig. 11). Both wells have declining groundwater levels during the time period when data are available (2008-2012), most likely due to climatic influence. The simulated groundwater levels closely match the observed groundwater levels calculated by the groundwater-flow model for both wells (figs. 29 and 30) both in values and in the downward trend.

Well CTF-197 (130 ft deep), located in the northern part of the CSNWR (fig. 11), is a Crouch Branch aquifer well that recorded variable groundwater levels from 2008 to 2012 (fig. 29). Water levels declined from 2008 to 2009, rose sharply in 2010, and declined in 2011 and 2012. Simulated groundwater levels show a slight decline from 2008 to 2012 but do not show the annual variability of the average observed water levels, most likely due to the yearly stress periods of the model.

Well CTF-189 (90 ft deep), located about 3 mi northwest of McBee (fig. 11), is a shallow Crouch Branch aquifer well that clearly records annual climatic fluctuations in the groundwater levels recorded from 2008 to 2012 (fig. 29). Groundwater levels in CTF-189 declined in 2009, increased in 2010, and have steadily declined since 2010 , most likely due to climatic influence. Simulated groundwater levels in CFT-189 closely match observed levels in trend and magnitude.

Well CTF-211 (185 ft deep) is a Crouch Branch aquifer well located on U.S. Highway 1 about 3 mi northeast of McBee in the CSNWR (fig. 11). Groundwater levels in CTF-211 are influenced by seasonal agricultural irrigation pumping from the northernmost irrigation wells (fig. 10). Groundwater levels have trended downward for the period of monitoring (2008-2012) because of climatic and nearby pumping influences. Simulated groundwater levels at CTF-211 closely match the observed groundwater levels in magnitude and trend (fig. 29).

Well CTF-56 (23 ft deep) is a shallow Crouch Branch aquifer well (fig. 11) located in the Cheraw National Fish Hatchery. Groundwater levels in CTF-56 respond to precipitation events and therefore have a strong climatic influence but have been relatively steady from 2008 to 2012 . Simulated groundwater levels for CTF-56 produce an acceptable fit to observed groundwater levels in 2008 and 2009 and produce a close match in 2010-2012 in trend and magnitude (fig. 29).

Well DAR-96 (380 ft deep) is an unused production well screened in the McQueen Branch aquifer in Society Hill, S.C. (fig. 11). Groundwater levels in the well have not trended up or down during 2008-2012. Simulated groundwater levels from DAR-96 match the trend but are about $16 \mathrm{ft}$ higher than the observed levels (fig. 30).

The groundwater-flow model used the MODFLOW Drain package (Harbaugh and others, 2000) to simulate streams in the study area. Conceptually, the streams are always gaining reaches and are losing reaches only under extreme hydrologic conditions. The MODFLOW Drain package removes water from the aquifer as long as the water table is above the altitude of the drain. If the water table falls below the altitude of the drain, the drain has no effect. The rate of removal is proportional to the difference in altitude between the water table and the drain. The constant of proportionality is the conductance of the fill material surrounding the drain. The drain locations (fig. 13) were derived from the 1:24,000scale National Hydrography Dataset (NHD; U.S. Geological Survey, 2010) and were placed in the groundwater model. The drain altitudes were interpolated from a 30-meter by 30-meter DEM derived from the USGS National Map and referenced to NAVD 88. A constant value of drain conductance was applied to each stream, and the altitude of the drain was linearly interpolated from upstream to downstream. There are no known values of drain conductance in the study area, so the values were estimated during the model calibration process. Calibrated drain conductance values in the model ranged from 1 to 687 cubic feet per day per foot $\left[\left(\mathrm{ft}^{3} / \mathrm{d}\right) / \mathrm{ft}\right]$. 
Well CTF-222

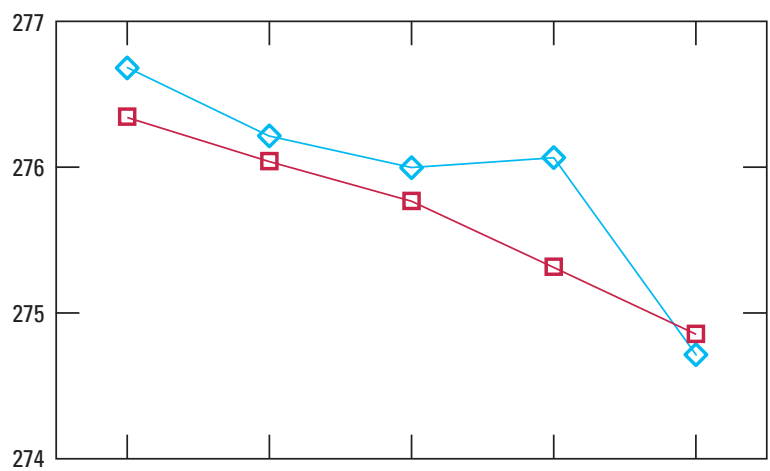

Well CTF-189
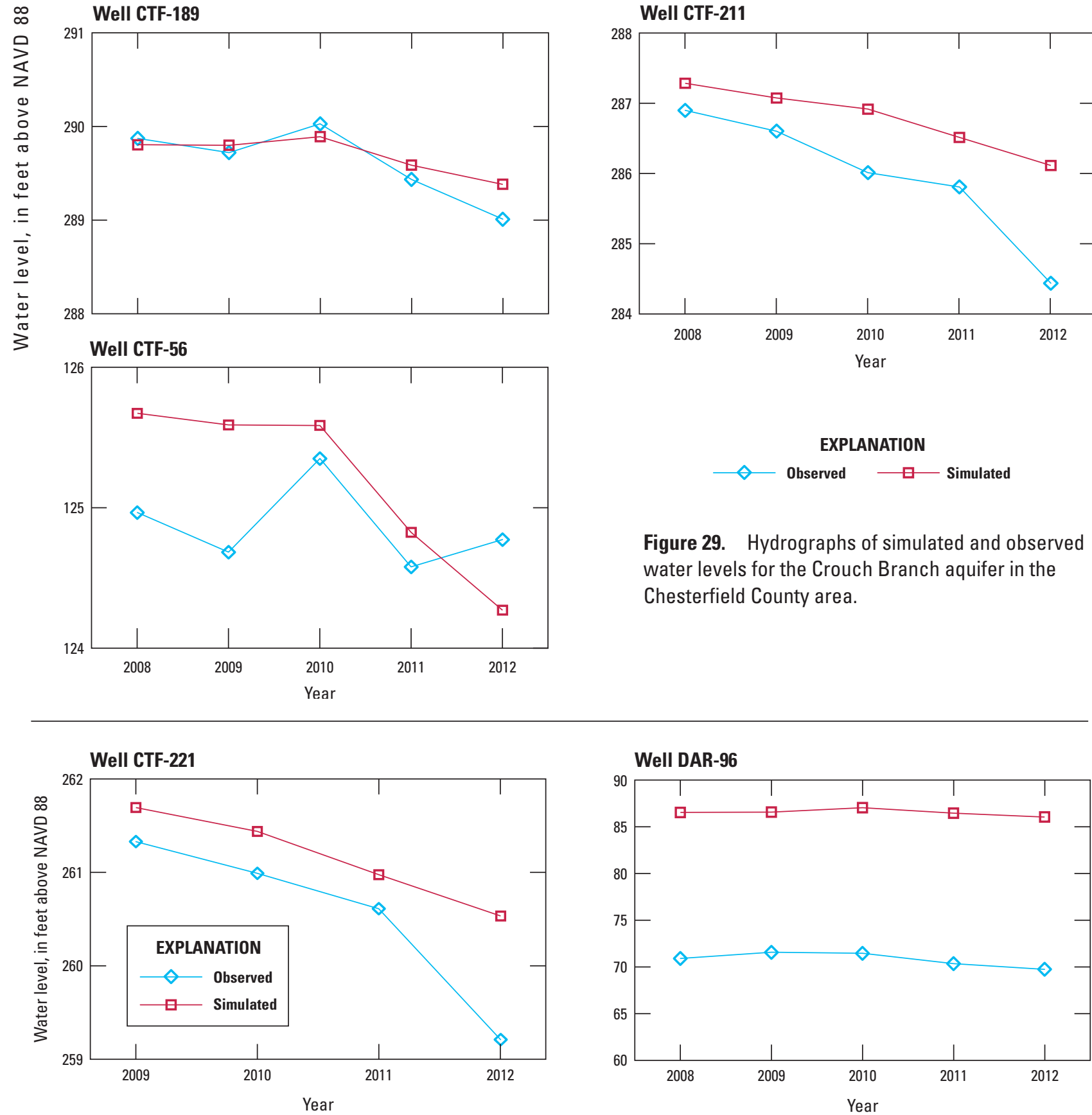

Figure 30. Hydrographs of simulated and observed water levels for the McQueen Branch aquifer in the Chesterfield County area.
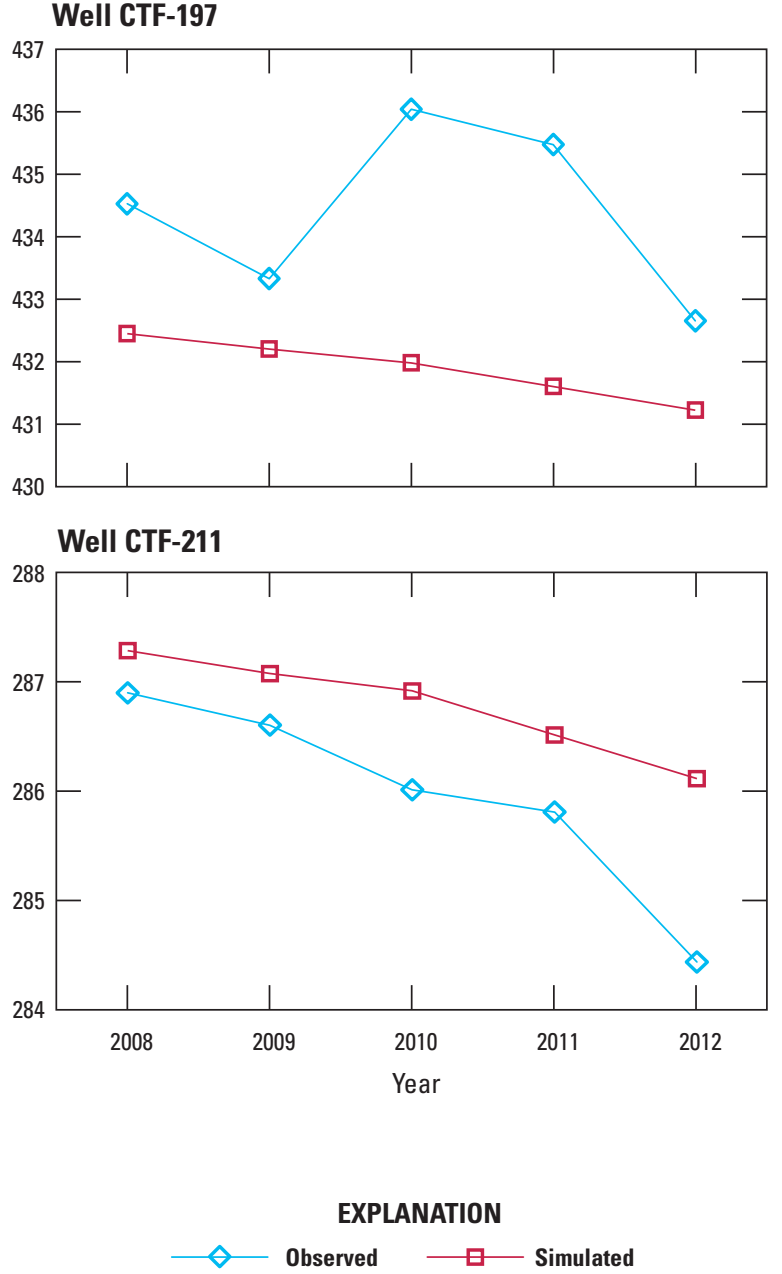

Figure 29. Hydrographs of simulated and observed water levels for the Crouch Branch aquifer in the Chesterfield County area. 
Simulated flows from the MODFLOW Drain package can be compared to observed stream base flows to determine how well the model is calibrated to field conditions. Five long-term USGS gaging stations with multiple years of daily discharge records form the basis of the flow calibration (fig. 3). The annual mean base flow (estimated from annual mean streamflow by using a 76-percent base-flow index) was used in the model calibration process because the shortest model stress period was 1 year (fig. 15). A calibration criterion of \pm 30 percent is used to evaluate the fit between the observed and simulated flows. The three gaging stations on Black Creek (fig. 19) have acceptable fits for the observed and simulated data (table 1). Black Creek below Chesterfield (02130840) has the shortest record of the three sites (2006-2012); however, the groundwater-flow model simulates the base flow at this site fairly well (fig. 31). The magnitude of the changes in observed flow (as much as 6 million cubic feet per day $\left[\mathrm{Mft}^{3} / \mathrm{d}\right]$ ) is not captured by the model, but the overall simulated flow (3.3 to $4.0 \mathrm{Mft}^{3} / \mathrm{d}$ ) is similar in trend.

Black Creek near McBee (02130900) has daily discharge records from 1960 to 2012, which were converted to annual mean base-flow values that were used in the model calibration (fig. $31 B$ ). Observed Black Creek annual mean base-flow discharges at this gaging location range from $4.5 \mathrm{Mft}^{3} / \mathrm{d}$ to $22.9 \mathrm{Mft}^{3} / \mathrm{d}$ depending on rainfall in the basin because there is no substantial regulation or storage upstream from the gage location. The lowest observed base flow $\left(4.5 \mathrm{Mft}^{3} / \mathrm{d}\right)$ at the Black Creek near McBee gage was in 2002 at the end of the 1998-2002 drought (Gellici and others, 2004). The highest annual base flow recorded for the period of record, $22.9 \mathrm{Mft}^{3} / \mathrm{d}$, was observed in 1998. Since 1998, the general trend of stream discharge has tended toward lower flows. The groundwater-flow model for Chesterfield County simulates the magnitude and trend of the observed base-flow discharges at the Black Creek near McBee gage.

Black Creek near Hartsville (02130910) has daily discharge records from 1961 to 2012, which were converted to annual mean base-flow values (based on the 76-percent hydrograph separation index) that were used in the model calibration (fig. 31C). Observed Black Creek base-flow discharges at this gaging location range from $6.8 \mathrm{Mft}^{3} / \mathrm{d}$ to $30.9 \mathrm{Mft}^{3} / \mathrm{d}$, depending on rainfall in the basin and the regulation from Lake Robinson, just upstream from the gage (fig. 6). The lowest observed base flow $\left(6.8 \mathrm{Mft}^{3} / \mathrm{d}\right)$ at the Black Creek near Hartsville gage was in 2002 at the end of the 1998-2002 drought (Gellici and others, 2004). The highest annual base flow for the period of record, $30.9 \mathrm{Mft}^{3} / \mathrm{d}$, was observed in 1998. Since 1998, the overall trend of stream discharge has tended toward lower flows. The groundwaterflow model simulates the general magnitude and trend of the observed base-flow discharges at the Black Creek near Hartsville gage. The three Black Creek gages ( 02130840 , 02130900, and 02130910) meet the \pm 30 -percent million cubic feet per day calibration criteria.

\section{A. Black Creek below Chesterfield, SC (02130840)}

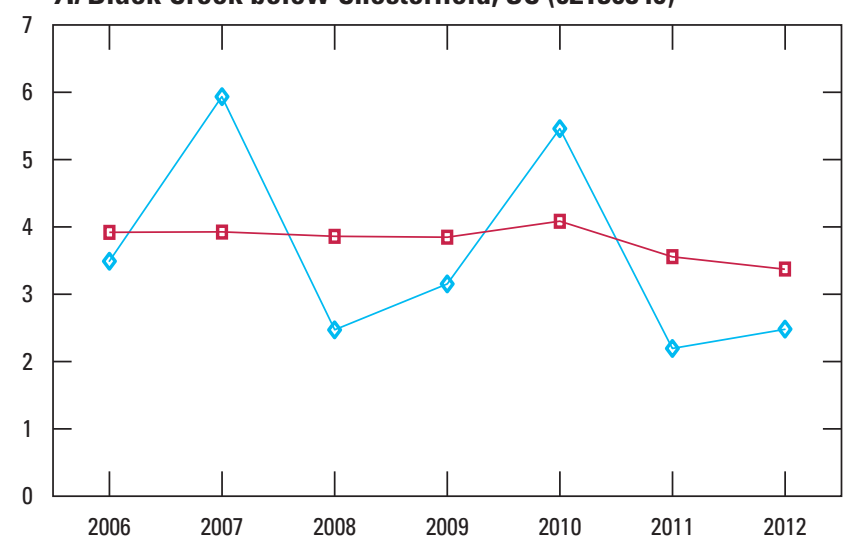

B. Black Creek near McBee, SC (02130900)

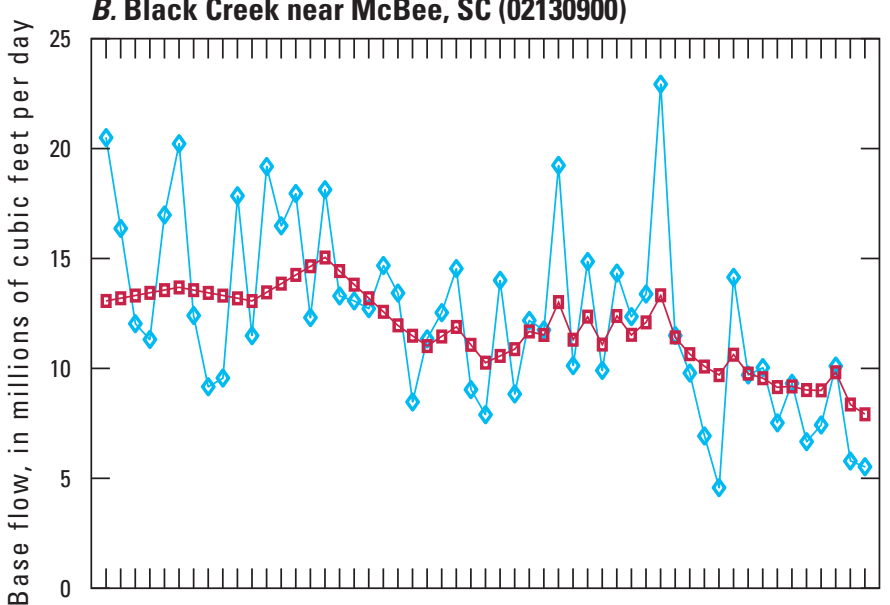

C. Black Creek near Hartsville (02130910)

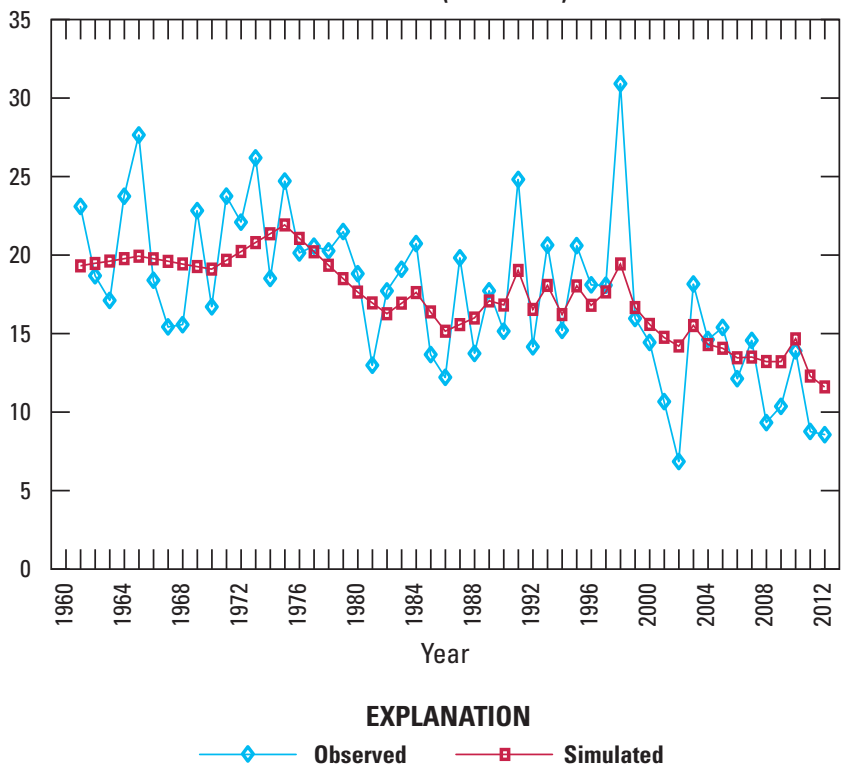

Figure 31. Hydrographs of simulated and observed base flows in Black Creek at three gaging stations in the Chesterfield County area: Black Creek below Chesterfield (02130840), Black Creek near McBee (02130900), and Black Creek near Hartsville (02130910). 
Two discontinued streamgages, Cedar Creek at Society Hill, S.C. (02130600) and Juniper Creek near Cheraw, S.C. (02130500), were used in the groundwater-flow model calibration process (fig. 3). Data from the Cedar Creek at Society Hill station included 46 discrete streamflow measurements from 1949 to 1981 that were converted to annual base flows according to the model stress periods by using the 76-percent hydrograph separation index. The model does not simulate the variability of the observed base-flow data but does simulate the overall base-flow magnitude and trend at this location. Data from the Juniper Creek near Cheraw station included 17 discrete streamflow measurements from 1941 to 1958 (fig. 32) that were converted to annual base flows according to the model stress periods using the 76-percent hydrograph separation index. The model does not simulate the variability of the observed base-flow data at this location primarily because of the 10-year stress periods representing the period from 1900 to 1960 (fig. 15). However, the groundwater-flow model simulates the magnitude of base flow at this location (fig. 32) with acceptable accuracy. These two discontinued gages (02130600 and 02130500 ) meet the \pm 30 -percent million cubic feet per day calibration criteria.

Previous studies (Bloxham, 1976, 1979; Barker, 1986; Zalants, 1991) document streamflow measurements at 15 sites (table 1; fig. 13) in the study area that are used for model calibration purposes. These streamflow measurements were typically collected during low-flow periods and have multiple (4 to 12) streamflow measurements that were collected in the 1960s, 1970s, and 1980s. The streamflow measurements were converted to base-flow values (based on the 76-percent hydrograph separation index) that were used in the model calibration. The simulated base flows typically match the overall magnitude of the observed base flows but do not match the variability in most cases. The time period of 1965 to 1988 in the model is discretized into 2- or 5-year stress periods in the simulation and cannot capture the base-flow variability in detail. Of the 15 sites, 2 meet the \pm 30 -percent million cubic feet per day calibration criteria.

Discrete streamflow measurements were made during the course of this study (2008-2012) at 24 sites (table 1; fig. 13) in the study area to provide data for calibration purposes at locations where long-term measurements were not available. These were typically smaller streams with observed flows that ranged from about $10,000 \mathrm{ft}^{3} / \mathrm{d}\left(0.1 \mathrm{ft}^{3} / \mathrm{s}\right)$ to $13 \mathrm{Mft}^{3} / \mathrm{d}\left(155 \mathrm{ft}^{3} / \mathrm{s}\right)$ and with a mean flow of about $1 \mathrm{Mft}^{3} / \mathrm{d}\left(12 \mathrm{ft}^{3} / \mathrm{s}\right)$. These discrete streamflow measurements were converted to base-flow values (based on the 76-percent hydrograph separation index) and were used in the model calibration. Overall, the simulated base flows compared to the observed base flows from the groundwater-flow model are a poor fit on these smaller streams. Only 7 of the 24 observed compared to simulated base-flow values fell within the \pm 30 -percent million cubic feet per day calibration criteria, and 17 did not meet the \pm 30 -percent criteria. Having these data in the parameter estimation process, however, provided valuable information in parts of the study area where no other observation data were available.

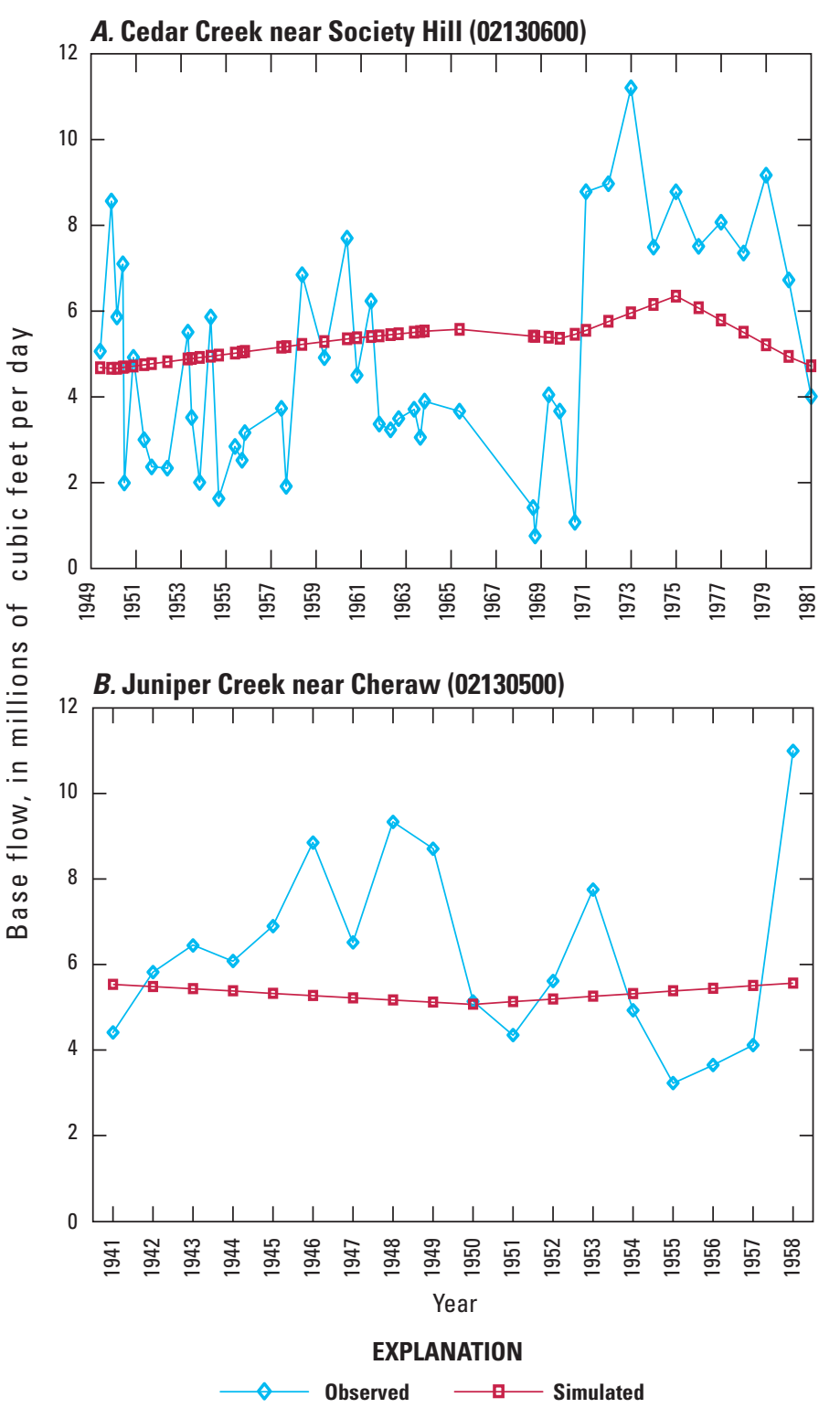

Figure 32. Hydrographs of simulated and observed base flows at Cedar Creek near Society Hill, South Carolina (02130600) and Juniper Creek near Cheraw, South Carolina (02130500). 


\section{Parameter Sensitivity}

As part of the PEST process, relative sensitivity values were calculated for all of the input parameters, and an analysis of these values was conducted. A sensitivity analysis is a systematic evaluation to identify the parameters that have the greatest potential effect on simulation results. Parameter sensitivity was assessed as part of the automated calibration process by using the PEST Jacobian matrix (Doherty, 2008a, b). The PEST algorithm uses the sensitivity of simulated calibration-target values to small adjustments in simulation parameters to guide the selection, in sequence, of candidate parameter values. The 944 parameters used in this groundwater-flow model were ranked (1 to 944) by relative sensitivity and plotted by category. The parameter category types are (1) drain conductance, (2) horizontal anisotropy pilot points in the Crouch Branch aquifer, (3) horizontal anisotropy in the McQueen Branch confining unit, (4) horizontal anisotropy pilot points in the McQueen Branch aquifer, (5) horizontal hydraulic conductivity pilot points in the Crouch Branch aquifer, (6) horizontal hydraulic conductivity pilot points in the McQueen Branch confining unit, (7) horizontal hydraulic conductivity pilot points in the McQueen Branch aquifer, (8) recharge fluxes, and (9) specific storage values.

There are few drain conductances (of the 160 total) that are sensitive; none of the conductance parameters are in the top 100 rankings (fig. 33A). About 70 percent of the horizontal anisotropy pilot point parameters (41 total) for the Crouch Branch aquifer are in the top 100 sensitivity rankings (fig. 33B) making this category one of the most sensitive in the model. Six horizontal anisotropy parameters for the Crouch Branch aquifer are in the top 10 most sensitive parameters. Only one parameter for horizontal anisotropy is used in the model for the McQueen Branch confining unit, and it is relatively insensitive. About 25 percent of the horizontal anisotropy pilot point values (41 total) for the McQueen Branch aquifer are in the top 100 sensitivity rankings, making this category somewhat sensitive (fig. 33C). About 10 percent of the horizontal hydraulic conductivity pilot points (304 total) in the Crouch Branch aquifer are in the top 100 rankings (fig. 34). However, two of these pilot points are the fourth and fifth most sensitive parameters. Only two horizontal hydraulic conductivity pilot points (160 total) for the McQueen Branch confining unit are in the top 100 sensitivity rankings (fig. 34B), making this category relatively insensitive. Nine horizontal hydraulic conductivity pilot points (170 total) for the McQueen Branch aquifer are in the top 100 sensitivity rankings (fig. 34C), making this category somewhat sensitive.

Net recharge flux sensitivities were calculated for the wetland and upland areas, and this is the only parameter category that also varies by model stress period (fig. 35). The simulation time, from 1900 to 2012, is divided into 39 stress periods of various time increments, and each of
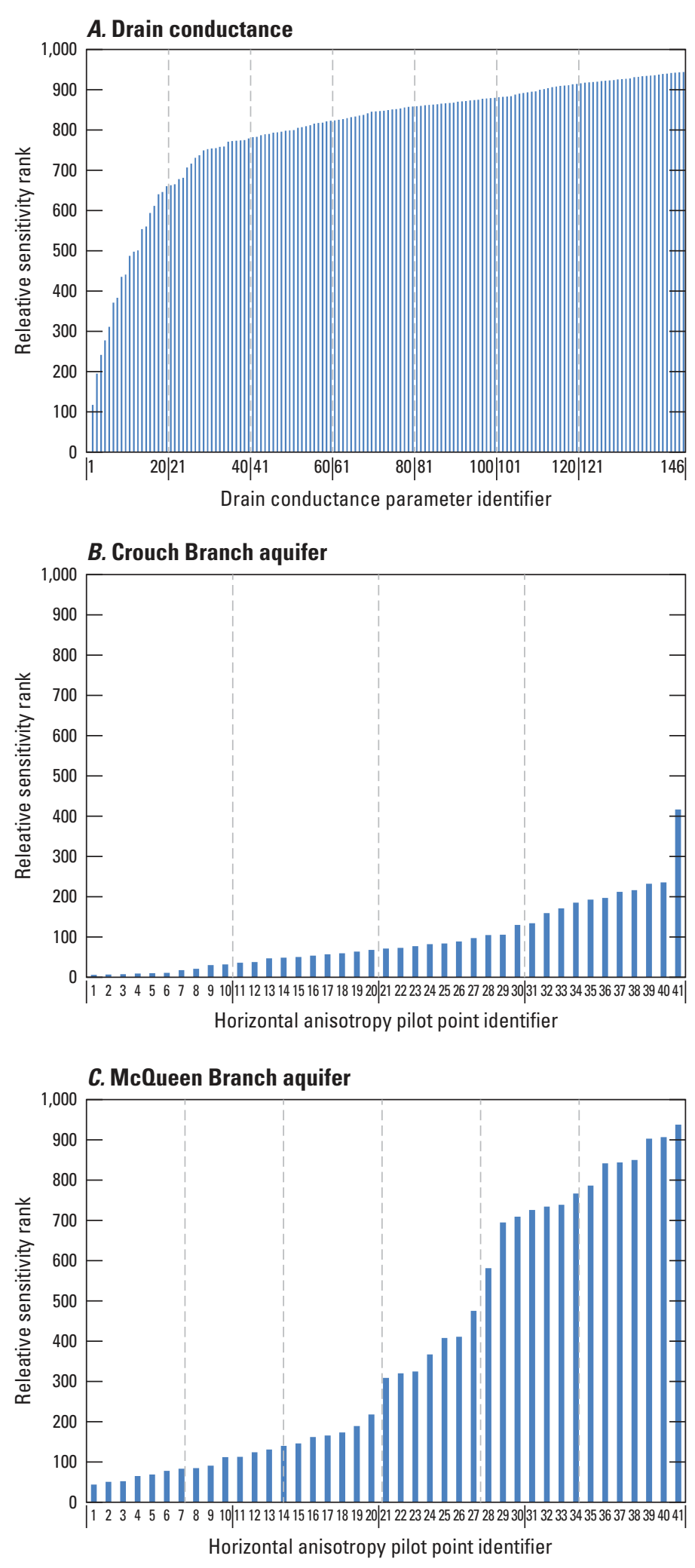

Figure 33. Sensitivity rankings for $A$, drain conductances, $B$, horizontal anisotropy parameters for the Crouch Branch aquifer, and $C$, horizontal anisotropy parameters for the McQueen Branch aquifer in the Chesterfield County area. 

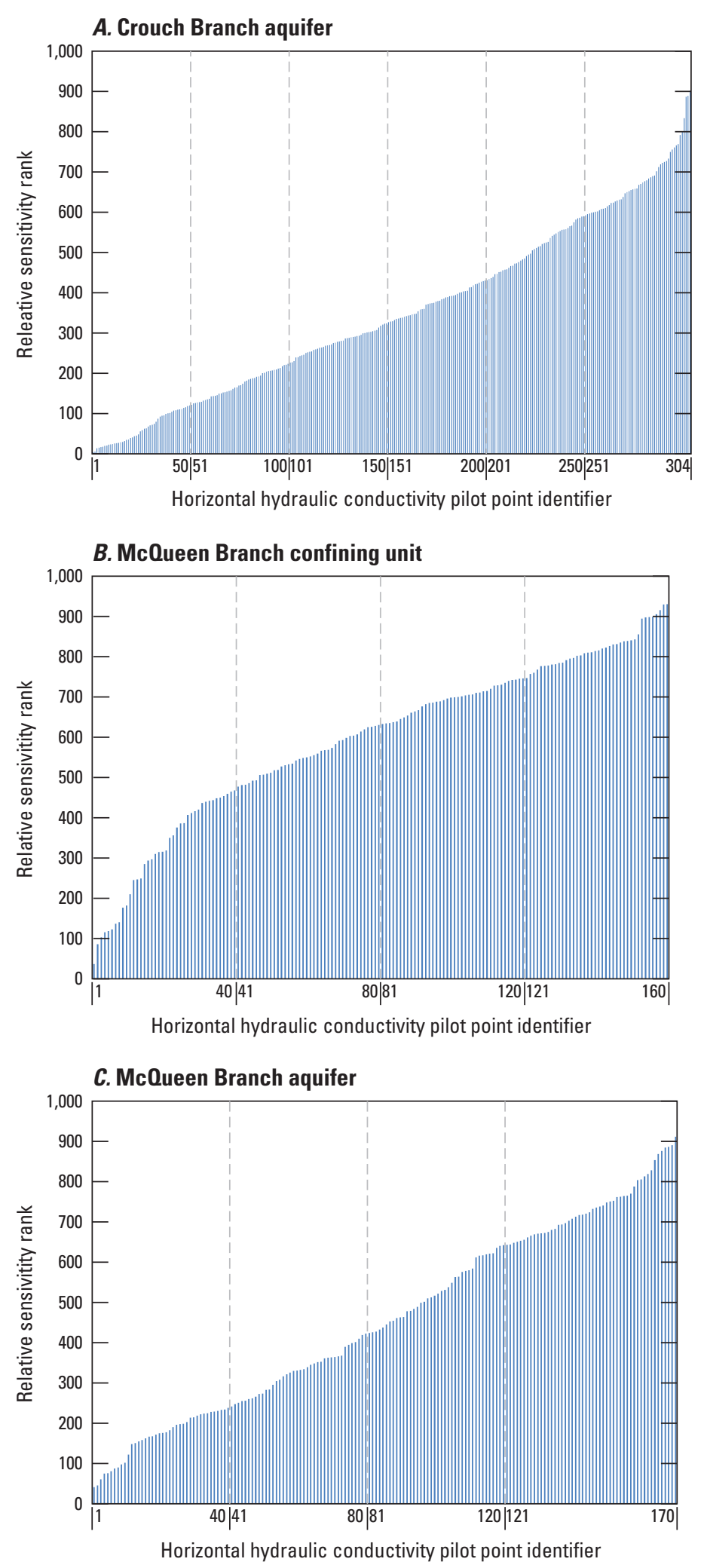

Figure 34. Sensitivity rankings for horizontal hydraulic conductivity pilot point parameters for $A$, the Crouch Branch aquifer, $B$, the McQueen Branch confining unit, and $C$, the McQueen Branch aquifer in the Chesterfield County area. these stress periods has a parameter value for net recharge and therefore a sensitivity ranking. Twelve net recharge flux parameters (of 78 total net recharge flux parameters) are in the top 100 rankings, with the upland area parameter for the first stress period being the most sensitive parameter in the model. Generally, the parameters representing the earlier stress periods for the uplands areas are more sensitive than the later stress periods. The sensitivities for the wetlands areas are more variable, with the earliest stress periods and the stress periods centered on stress period nine being somewhat sensitive.

The Crouch Branch aquifer, the McQueen Branch confining unit, and the McQueen Branch aquifer each have a specific storage parameter. The specific storage parameter for the Crouch Branch aquifer is the third most sensitive parameter in the model, but the other two specific storage parameters are relatively insensitive.

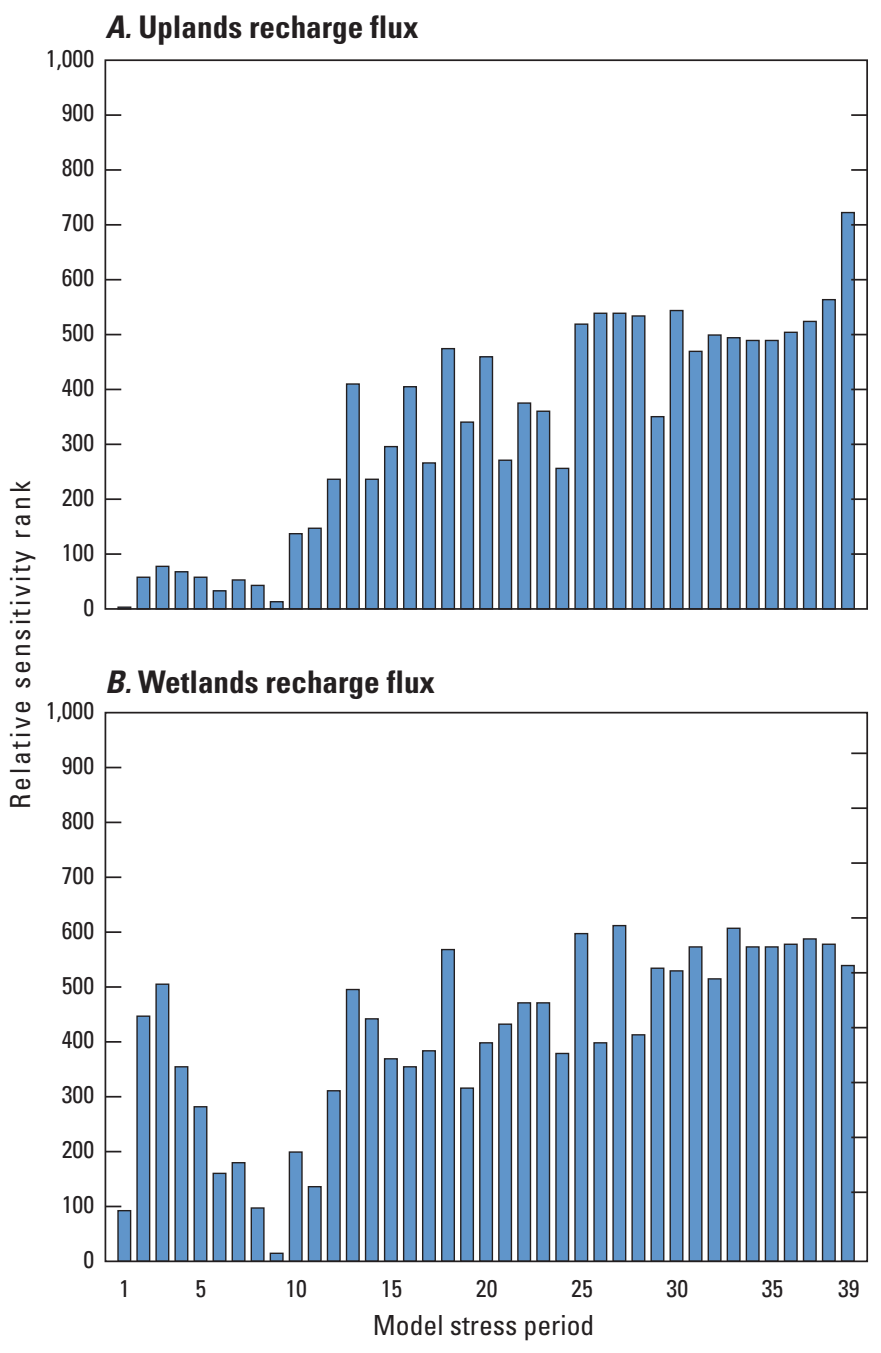

Figure 35. Sensitivity rankings for recharge fluxes on $A$, uplands and $B$, wetlands areas in the Chesterfield County area. 


\section{Groundwater Budgets}

Water budgets are presented for the overall study area (figs. 36 and 37) and two subareas: (1) the McBee area, centered on the ARWS well field and (2) the CSNWR acquisition area (fig. 38). These water budgets consist of the various components of the groundwater-flow system that are simulated with the groundwater-flow model documented in the previous sections of this report. An analysis of the potential for withdrawals from the various types of wells in the McBee area to affect local stream base flows is presented.

The overall transient (1900-2012) water budget simulated by the groundwater-flow model for the study area consists of the following components: storage-in, storage-out, multi-node wells-in, multi-node wells-out, recharge, drains (streams and rivers), wells-out, time-varying specified head-in, and time-varying specified head-out (Pee Dee River and southeastern lateral model boundary). Simulated groundwaterflow budgets for the area are presented in several ways. First is the simulated major water-budget components in the study area from 1900 to 2012 (fig. 36). Next are water budgets that quantify the inflow and outflow of water to and from the groundwater-flow system for each hydrologic component and model layer for 1998 (a wet year) and 2012 (a dry year) (fig. 37). The wet year-dry year comparison illustrates the large differences in groundwater-flow budgets that can take place under different hydrologic conditions.

The McBee subarea was selected for detailed analysis because of the relatively long history of groundwater use and detailed records of groundwater use and water-level data that are available. The volume of groundwater use in the McBee area is also some of the highest in the study area; this analysis could help water managers in these areas understand the potential effect of this pumpage on the water resources of the area. The CSNWR subarea was selected to provide the refuge managers with a tool to assist in the management of the water resources of the 46,000-acre refuge.

The budgets are broken down into the 39 stress periods that vary over time, with the largest components of the 1900-2012 water budget being drains and net recharge (fig. 36). Recharge rates vary from 56 to $1,679 \mathrm{Mgal} / \mathrm{d}$ with a mean of $737 \mathrm{Mgal} / \mathrm{d}$ (fig. 37). The simulated water budget for the drains (streams and rivers) varies from 653 to $1,127 \mathrm{Mgal} / \mathrm{d}$ with a mean of $944 \mathrm{Mgal} / \mathrm{d}$. The next largest budget component is storage, both inflow and outflow. Storage terms related to groundwater can be defined as the volume of water released or taken into storage per unit volume of a porous medium per change in head (Fetter, 1988). The simulated storage-in term ranges from 0 to $568 \mathrm{Mgal} / \mathrm{d}$ with a mean of $276 \mathrm{Mgal} / \mathrm{d}$. The simulated storage-out term has a range of 0 to $556 \mathrm{Mgal} / \mathrm{d}$ with a mean of $77 \mathrm{Mgal} / \mathrm{d}$. The next largest budget components are inflows and outflows through the specified-head boundaries. Flow from or to the specifiedhead boundaries is derived from the vertical and horizontal hydraulic gradient at the boundary. The total inflow varies from 97 to $111 \mathrm{Mgal} / \mathrm{d}$ with a mean of $103 \mathrm{Mgal} / \mathrm{d}$ through all specified-head boundaries and has a slightly increasing trend over the simulation time, indicating less net water is moving across the boundary - or conversely, more water is moving into the area from outside of the model. The total outflow through all specified-head boundaries varies from 68 to $86 \mathrm{Mgal} / \mathrm{d}$ with a mean of $79 \mathrm{Mgal} / \mathrm{d}$ and has a slightly decreasing trend over the simulation time. The smallest budget component is from the various wells simulated in the groundwater-flow model. The WEL package simulates withdrawals that range from 0 to $6.7 \mathrm{Mgal} / \mathrm{d}$ with a mean of 3.0 Mgal/d over the simulation time from 1900 to 2012. The MNW1 package (which incorporates the well screen settings and depth) simulates withdrawals that range from 0 to $9.3 \mathrm{Mgal} / \mathrm{d}$ with a mean of $5.2 \mathrm{Mgal} / \mathrm{d}$ over the simulation time from 1900 to 2012. 


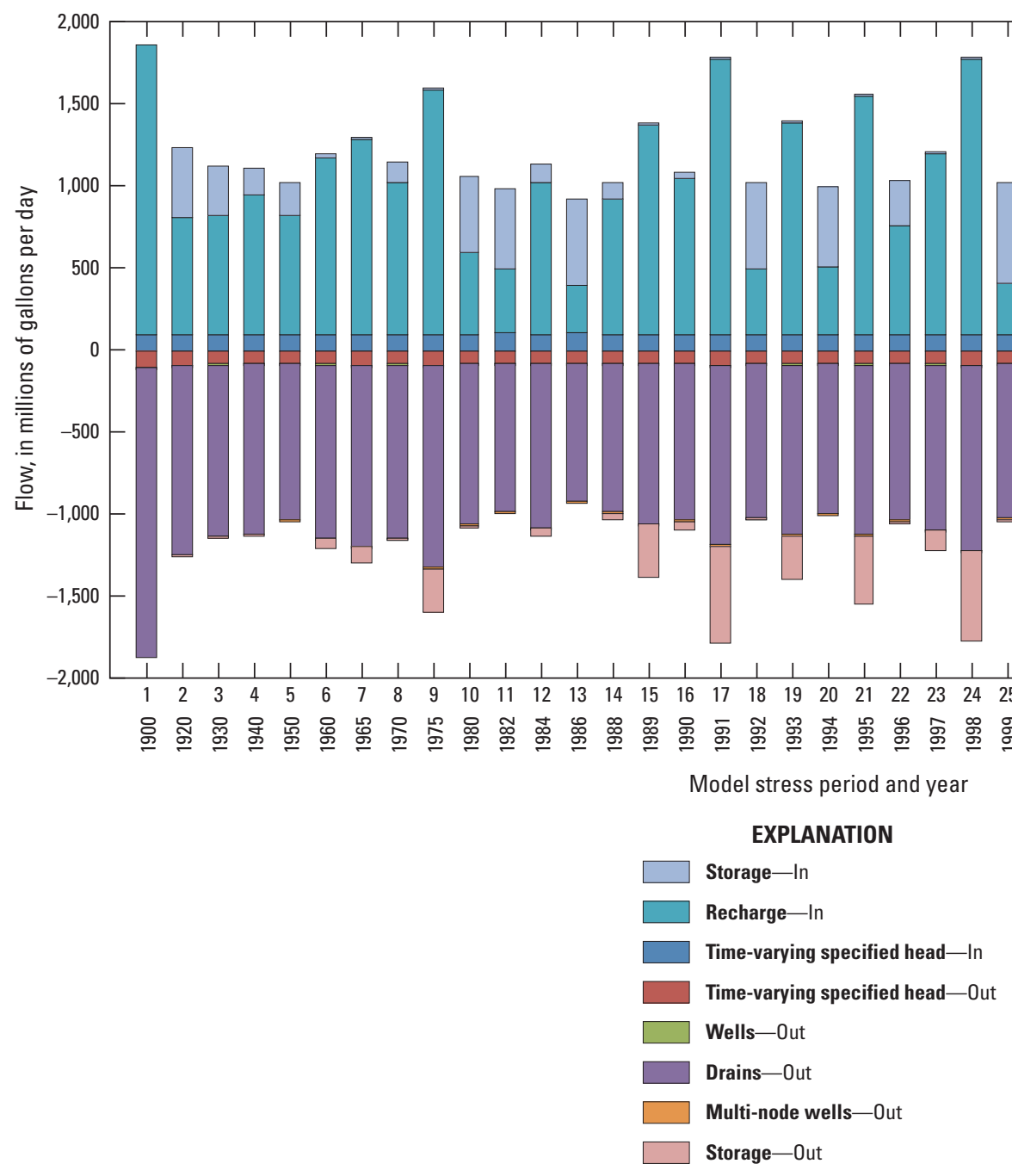

Figure 36. Simulated water budget per stress period in the Atlantic Coastal Plain from predevelopment (1900) to 2012 in the Chesterfield County area. 

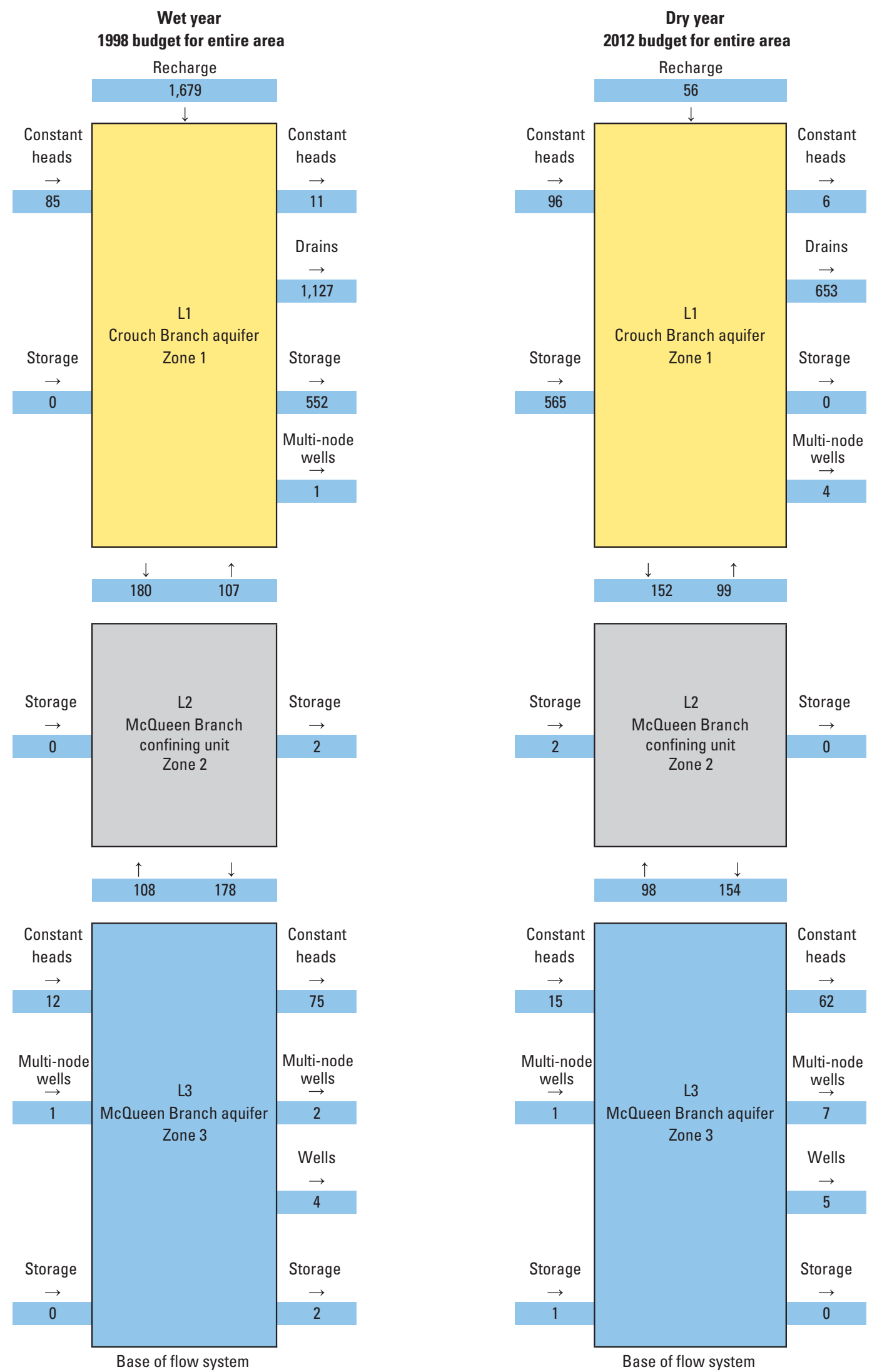

Figure 37. Water budgets for wet (1998) and dry (2012) years for the Chesterfield County area. (All units are in million gallons per day.) 


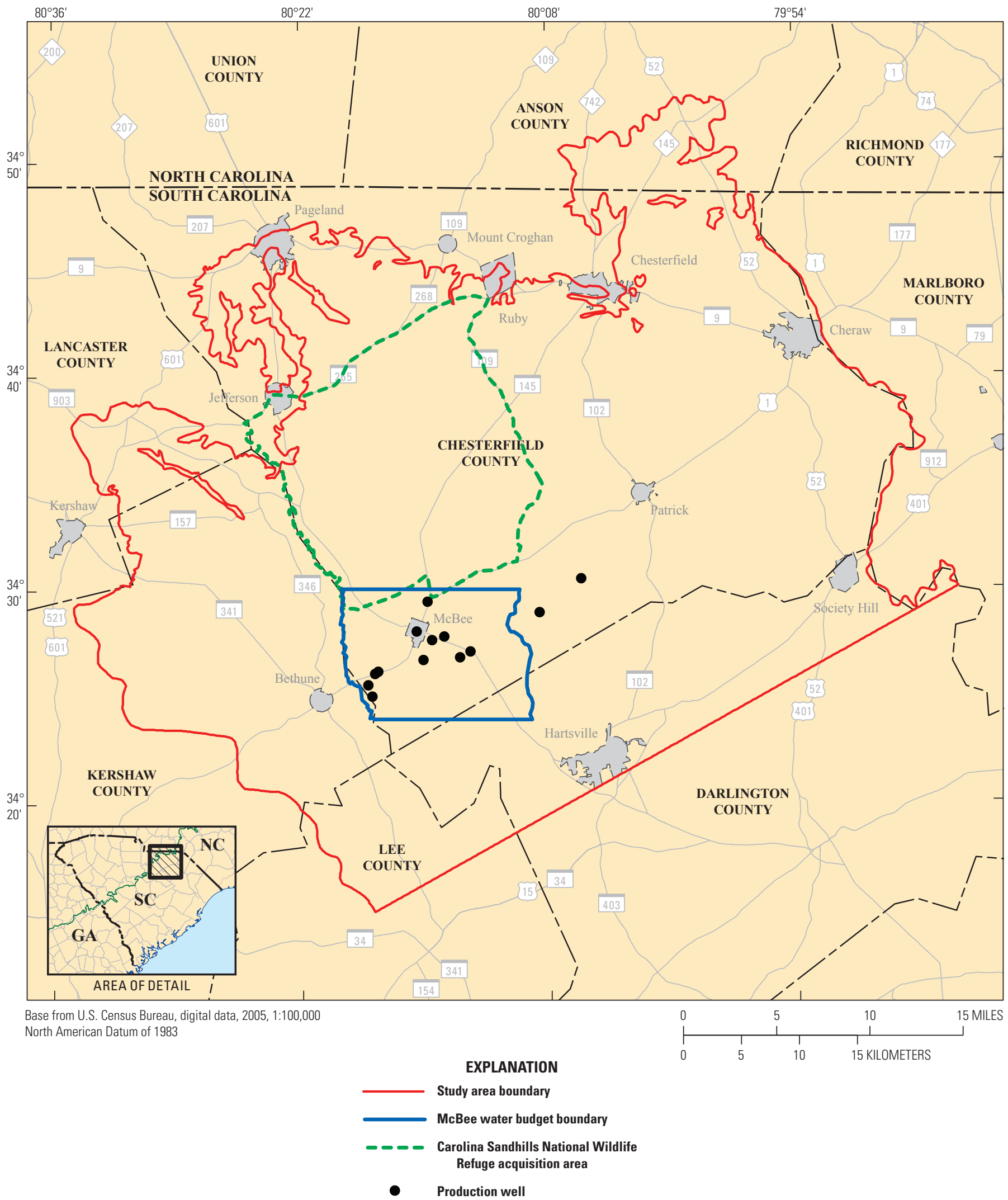

Figure 38. Water budget areas for the Alligator Rural Water and Sewer Company well field near McBee, South Carolina, and the Carolina Sandhills National Wildlife Refuge acquisition area, Chesterfield County. 


\section{McBee Area Groundwater Budget}

A water budget was derived from the calibrated Chesterfield County area groundwater-flow model for the McBee area, centered on the ARWS well field, which supplies most of the potable water for Chesterfield County (fig. 38). Two of the ARWS wells that are located east of Black Creek (fig. 1) are not included in the water budget analysis because they have provided very little of the total volume of water produced by the well field and they may be abandoned in the near future (Glenn Odom, Alligator Rural Water and Sewer Company, oral commun., 2011). The area chosen for analysis includes 11 ARWS wells and extends from the Lynches River on the west to Black Creek on the east. The Lynches River and Black Creek surface-water features were chosen to reflect the groundwater-flow system boundary conditions at these two incised stream valleys in the Crouch Branch aquifer. The water budgets for a wet year (1998) were compared to that of a dry year (2012).

The lower units (McQueen Branch confining unit and the McQueen Branch aquifer) have similar budgets in wet and dry years (fig. 39). The budgets for the Crouch Branch aquifer, however, are different for the wet and dry years. In the wet year (1998), water going into storage (30.2 Mgal/d) is one of the largest budget terms, while in the dry year (2012), water flowing into the Crouch Branch aquifer from storage is the largest budget term $(39.9 \mathrm{Mgal} / \mathrm{d})$. Streamflow in the wet year is $47.1 \mathrm{Mgal} / \mathrm{d}$ and is reduced to $30.9 \mathrm{Mgal} / \mathrm{d}$ in the dry year (2012). Total pumping from the well field (along with irrigation wells in the budget area) is $1.5 \mathrm{Mgal} / \mathrm{d}$ in 1998 and 4.0 Mgal/d in 2012 .

\section{Carolina Sandhills National Wildlife Refuge Groundwater Budget}

A groundwater budget for the CSNWR was developed by using the calibrated groundwater-flow model of the Chesterfield County area. The planned acquisition area for the CSNWR (Allyne Askins, U.S. Fish and Wildlife Service, written commun., 2013) was used for the boundary of the water budget area (fig. 38). The planned acquisition area is about 101,000 acres, and the current size of the CSNWR is about 45,000 acres. Most of the planned acquisition area is included in the Chesterfield County groundwater-flow model; however, a small area in the Lynches River valley is in the Piedmont Physiographic Province, outside of the study area, and is not included in the water budget calculations.

Two water budgets for the CSNWR are presented, one from a relatively wet year (1998) and one from a relatively dry year (2012) (fig. 40). The only groundwater pumping simulated in the CSNWR budget area is a small volume of irrigation pumping in the southern part of the area. Most of the water budget volumes are the natural components of the groundwaterflow system, and the two budgets represent how the natural system responds to wet and dry hydrologic conditions.

The largest components of the wet and dry year water budgets are net recharge, storage, and streamflows. In 1998, simulated net recharge was $231.9 \mathrm{Mgal} / \mathrm{d}$ with streamflows of 151.3 Mgal/d. In 2012, recharge was 31.4 Mgal/d, and stream base flows were $92.7 \mathrm{Mgal} / \mathrm{d}$ (fig. 40). Storage fluxes for the wet year (1998) were $78.4 \mathrm{Mgal} / \mathrm{d}$ into storage and $65.2 \mathrm{Mgal} / \mathrm{d}$ out of storage in 2012 because the low net recharge rate alters the flow budget. Most of the CSNWR acquisition area is underlain by only the Crouch Branch aquifer; the McQueen Branch confining unit and the McQueen Branch aquifer pinch out against the Piedmont crystalline bedrock in the southeastern part of the acquisition area. The water budgets for the McQueen Branch confining unit and the McQueen Branch aquifer, therefore, are relatively small compared to the water budget for the Crouch Branch aquifer. 

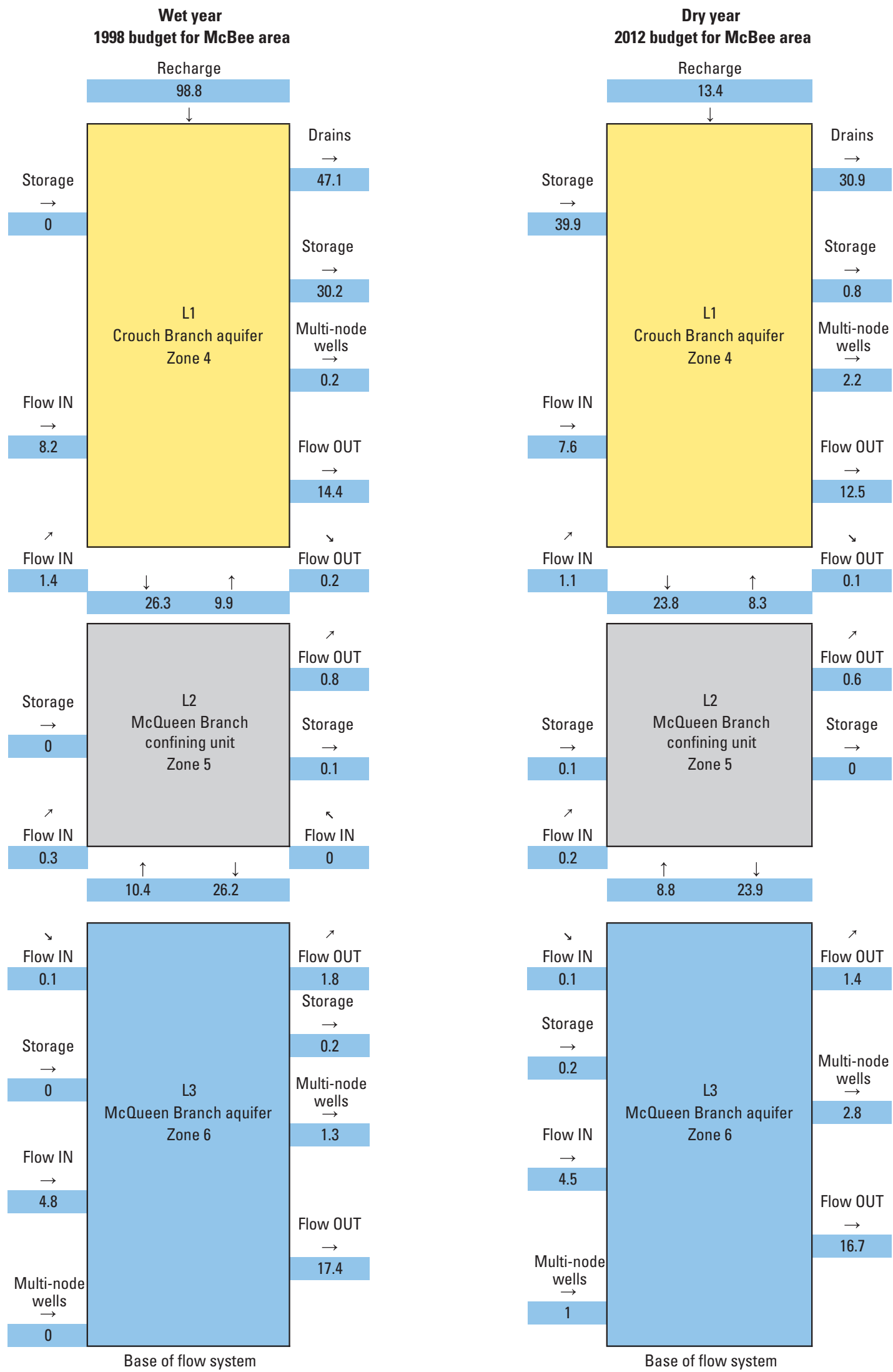

Figure 39. Water budget for wet (1998) and dry (2012) years for the McBee, South Carolina, area. (All units are in million gallons per day.) 

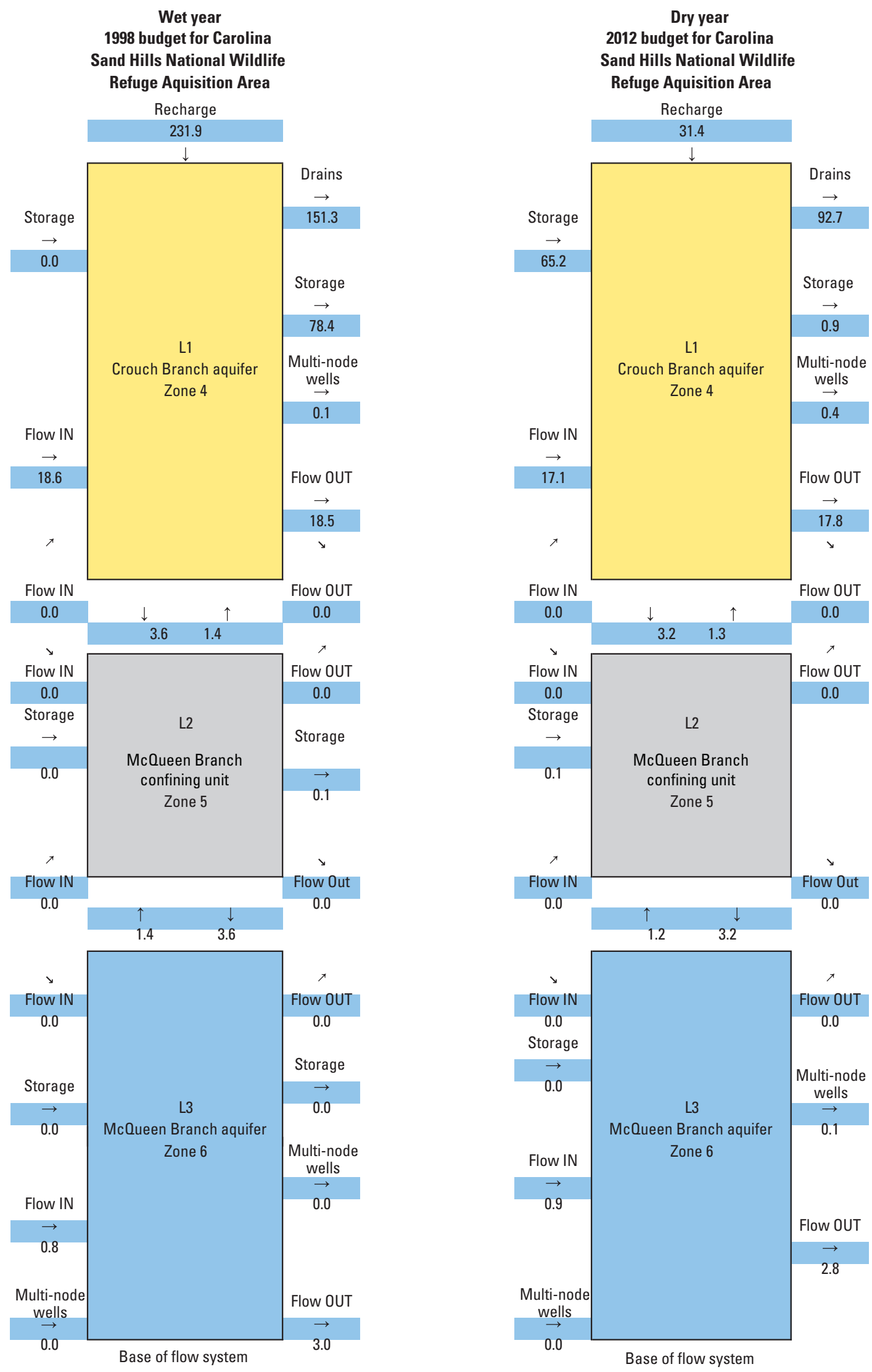

Figure 40. Water budget for wet (1998) and dry (2012) years for the Carolina Sandhills National Wildlife Refuge acquisition area, Chesterfield County, South Carolina. (All units are in million gallons per day.) 


\section{McBee Area Stream Base-Flow Budget Area}

A concern that has been expressed by SCDNR, local residents of the McBee area, and the CSNWR has been that pumping from the ARWS well field (and other wells in the area) is lowering groundwater levels and reducing stream base flows in the well field area. The water budgets for Cedar Creek, Lower Alligator Creek, two unnamed tributaries to the Lynches River near the U.S. Highway 1 crossing, Blackwell Creek, and the upper reaches of Beaverdam Creek (fig. 41) have been derived from the groundwater-flow model of the Chesterfield County area. These streams all have headwaters in or near the ARWS well field and have the potential for groundwater discharges to the streams to be lowered by pumping from the wells. Two simulated water budgets for selected streams from 2012 are presented: (1) the budget from the original model, which includes withdrawals from the ARWS well field along with nearby irrigation and industrial supply wells and (2) a modified version of the model with all pumping removed from the model throughout the simulation period.

Simulated stream base flows for 2012 for the selected streams in the ARWS well field area for the two versions of the model are similar (table 4). Removing all pumping from the model for the entire simulation period (1900-2012) produces negligible differences in base flow for the selected streams. The largest difference was for Lower Alligator Creek with an increase of $0.04 \mathrm{Mgal} / \mathrm{d}$ for the non-pumping budget. The 2012 flow for Lower Alligator Creek was 5.04 Mgal/d with the wells pumping and was $5.08 \mathrm{Mgal} / \mathrm{d}$ without the wells pumping. This small difference $(<1$ percent $)$ is within the acceptable model error. The other five streams selected for this base-flow analysis had similar results.

Table 4. Simulated 2012 base flows for McBee, South Carolina, area streams within the Alligator Rural Water and Sewer well field (see figure 41 for stream locations) under conditions of pumping and no pumping.

[Mgal/d, million gallons per day]

\begin{tabular}{lccc}
\hline \multicolumn{1}{c}{ Stream } & $\begin{array}{c}\text { Simulated base flow } \\
\text { with wells pumping }\end{array}$ & $\begin{array}{c}\text { Simulated base flow } \\
\text { with wells not pumping } \\
\text { In Mgal/d }\end{array}$ & Difference \\
\cline { 2 - 4 } & 6.97 & 6.99 & 0.02 \\
\hline Cedar Creek & 0.00 & 0.00 & 0.00 \\
Unnamed Tributary 1 & 0.06 & 0.06 & 0.00 \\
Unnamed Tributary 2 & 1.14 & 1.15 & 0.01 \\
Upper reaches of Blackwell Creek & 0.72 & 0.75 & 0.03 \\
\hline Upper reaches of Beaverdam Creek & 5.04 & 5.08 & 0.04 \\
\hline Lower Alligator Creek & & & \\
\hline
\end{tabular}




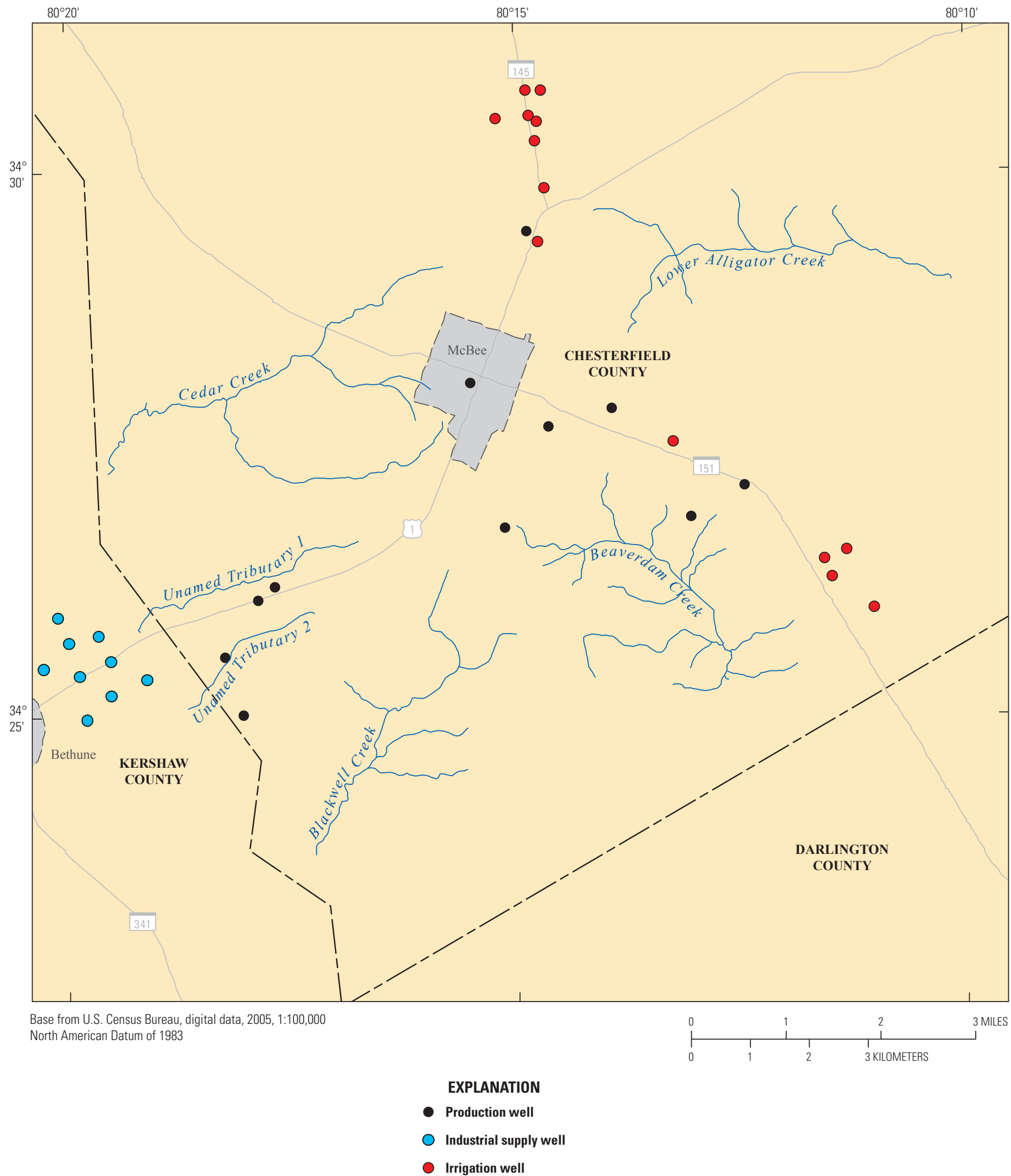

Figure 41. Selected streams for water-budget analysis in the McBee, South Carolina, area. 


\section{Model Uncertainties and Limitations}

Groundwater-flow models are based on limited data and are simplifications of natural systems. The simplifications incorporated into the development of a groundwater-flow model can limit the ability of the model to predict actual hydraulic conditions over time. Accuracy and prediction capabilities of this model are affected by the finite-difference discretization, boundary conditions, hydraulic properties, and observations used in the model calibration.

The model was spatially discretized into a grid of $300-$ by $300-\mathrm{ft}$ model cells and was temporally discretized into 1 steady-state stress period and 38 transient stress periods. The small size of the grid cells allows the model to relatively accurately simulate local flow conditions, such as discharge to wells or streams. The 39 transient stress periods range in length from 10 years (in the earlier periods of the model) to 1 year (in the more recent time periods of the model). The variable-length stress periods are appropriate for the accuracy of the water-use data and temporally sparse observations but cannot represent seasonal variations within the groundwater flow system.

Boundary choices can affect model uncertainty, run times, and stability. The boundaries defined for the model are, in some cases, true boundaries of the natural hydrologic system. In other cases, there is some uncertainty in the location of the boundary. The best available data were used to place the boundaries. The northeastern specified-head boundary in the model is placed at the Pee Dee River, which acts as natural hydraulic boundary for the incised hydrogeologic units. The southwestern boundary is placed at the topographic divide between the Little Lynches River and the Wateree River Basins. This topographic boundary is thought to be the same as the groundwater-flow divide, but the exact position of the groundwater divide is unknown. The northwestern no-flow boundary is placed at the Fall Line, or geologic boundary between the ACP sediments and the Piedmont crystalline rocks, and may not be precisely mapped. The Piedmont rocks underlying the modeled area are assumed to be impermeable and are simulated as a no-flow boundary; however, it is not known if these underlying Piedmont rocks are impermeable. The southeastern boundary is arbitrarily located to enclose the study area and is a specified-head boundary. The groundwater levels for this specified-head boundary are extrapolated from the predevelopment potentiometric-surface map, which may have uncertainty in the locations of equal potentiometric heads. Care should be taken, however, when interpreting simulated water levels near all model boundaries.

The recharge rate specified in the model was derived initially from rainfall data available for the study area.
However, the model calibration required a net recharge rate that did not include evapotranspiration or overland flow; therefore, the water budget term for recharge is based on the model calibration process which introduces uncertainty. The precipitation station represents a small fraction of the large area covered in the model where recharge is simulated, and precipitation data at the station were collected over a 112-year period; therefore, the precipitation data most likely are subject to an unknown degree of uncertainty.

Groundwater withdrawals simulated in the model may underrepresent actual historic water use because pumping rates less than $3 \mathrm{Mgal}$ per month are not required to be reported to the State environmental regulatory agency and therefore are unknown. Groundwater withdrawals prior to 1980 are uncertain and have been estimated from historical records. Many domestic water wells in the study area are not simulated in the groundwater-flow model because of the lack of location and withdrawal data. However, most of these domestic wells return much of the withdrawn groundwater back to the flow system through onsite septic systems.

Hydraulic properties of horizontal hydraulic conductivity, horizontal anisotropy, and specific storage were all calibrated to a large degree during the modeling process. Initial values of hydraulic conductivity and specific storage for the aquifer were derived from published transmissivity and storage coefficient data and are the best-defined hydraulic properties in the model. In some cases, however, aquifer thicknesses at the wells had to be assumed from screen length. All of the calibrated hydraulic-property distributions are large-scale approximations of measured and estimated values.

The hydraulic heads used as steady-state and transient calibration targets have uncertainty associated with the accuracy of the land-surface elevations of each well; the calibration target was to match simulated and observed water levels within $\pm 20 \mathrm{ft}$. In addition, the clustering of head data in some areas and the lack of head data in other areas can lead to areas being overemphasized or underemphasized, respectively, during model calibration. Care was taken during this study to limit the clustering of head data, but the lack of head data in some areas is a limitation that cannot be corrected.

Stream base flows simulated by the model accurately represent calculated base flows in some cases but not in all cases. A scale issue occurs between the 300 - by $300-\mathrm{ft}$ model cells and the stream widths that the model simulates, which are much less than $300 \mathrm{ft}$ during base-flow conditions. Because of this scale issue, the model is not capable of always accurately simulating base flow for many streams. In addition, the model is relatively insensitive to streambed conductance, and the calibrated values may not be accurate representations of true streambed conductances. 


\section{Summary}

The population of Chesterfield County grew at about a 9-percent rate during the last decade (2000-2010), and along with this rate of population growth is an increased demand for high-quality water for various uses in the Chesterfield County area and adjacent counties. Residential, agricultural, industrial, and other forms of development have increased during this time period and are expected to increase in the future. These increased demands for high-quality groundwater will put further pressure on the water resources of the region. Natural pressures, such as periodic severe droughts, also have placed additional stresses on the water resources of the area. Since about 2000, much of the demand for potable water in Chesterfield County has been met by withdrawals from the Alligator Rural Water and Sewer well field near McBee, South Carolina. Treated groundwater from the well field is piped to the towns of Jefferson, Pageland, Mount Croghan, Ruby, Chesterfield, and Patrick to supply most of the potable water needs of these communities.

Chesterfield County is home to the Sand Hills State Forest and the Carolina Sandhills National Wildlife Refuge. The Carolina Sandhills National Wildlife Refuge and the Sand Hills State Forest are located in central and southern Chesterfield County. These areas contain more than 95,000 acres of critical longleaf pine habitat and a protected population of endangered red-cockaded woodpeckers. A reduction in groundwater levels or groundwater base flows to surface-water bodies could have a negative effect on these valuable natural resources.

The Chesterfield County study area is composed of the Atlantic Coastal Plain (ACP) part of Chesterfield County and small parts of Darlington, Lee, and Kershaw Counties in northeastern South Carolina and Anson County in North Carolina, occupying approximately 1,117 square miles $\left(\mathrm{mi}^{2}\right)$. The study area is composed of parts of the ACP sediments and is bounded by the Fall Line to the northwest, the Pee Dee River to the northeast, the northern parts of Lee and Darlington Counties to the southeast, and the topographic divide between the Little Lynches River Basin and the Wateree River Basin in Kershaw County to the southwest. Because this region is covered by abundant white sand, this area is informally known as the Sandhills.

The hydrogeologic framework of Chesterfield County consists of two aquifers separated by a confining unit-the Crouch Branch aquifer, the McQueen Branch confining unit, and the McQueen Branch aquifer. The aquifers and confining unit are composed of sedimentary materials, such as gravel, sand, silt, and clay, with some small areas of lithified sandstone and are Late Cretaceous in age.

The groundwater assessment of the Chesterfield County area consisted of the collection, integration, and use of new and existing data along with the construction and calibration of a groundwater-flow model. The model is the primary tool used in the assessment of groundwater availability of the study area. Major types of data used in the study include groundwaterlevel data, groundwater-use data, hydrostratigraphic data such as aquifer and confining unit extents, estimates of stream base flows derived from the analysis of observed streamflows at selected sites, and precipitation data. Historical groundwater levels, groundwater-use data, and streamflows were compiled for 1900 to 2012 and used in the model construction and calibration process.

A conceptual flow-system model of the Atlantic Coastal Plain aquifers in Chesterfield County was developed as the basis for constructing the digital groundwater-flow model. The conceptual model is based on recharge, surface topography, properties and distribution of the hydrostratigraphic units, water-level data, stream base-flow data, hydrologic testing results, geochemical data, and previously published interpretations of the flow system. The Crouch Branch and McQueen Branch hydrostratigraphic units in the model area are the principal water-bearing units. Recharge to hydrostratigraphic units in the model area is from atmospheric precipitation that infiltrates through the surficial materials of the Crouch Branch aquifer at land surface. The Crouch Branch aquifer discharges water to springs, streams, rivers, and wells based on the potentiometric surfaces developed by this study. The deeper McQueen Branch aquifer does not crop out in the study area and discharges water to wells. Some groundwater from both aquifers flows laterally out of the study area downdip toward the Atlantic Ocean.

A finite-difference numerical model, MODFLOW-2000, was used to simulate groundwater flow in the aquifers and confining unit of the study area over a 112-year period from 1900 to 2012. The model grid consists of the lateral discretization of the model domain into rows and columns and the vertical discretization of the unconsolidated ACP deposits into layers. The MODFLOW finite-difference grid consists of 617 rows from north to south extending 35 miles (mi) and 884 columns from west to east extending $50 \mathrm{mi}$, yielding a total area of $1,750 \mathrm{mi}^{2}$. However, the active part of the model totaled $1,117 \mathrm{mi}^{2}$. The spacing of the rows and columns is uniform, $300 \mathrm{feet}(\mathrm{ft}$ ) by $300 \mathrm{ft}$, which was chosen to maximize the potential for accurate simulations of groundwater discharge to surface water. Vertically, the sediments are discretized into three model layers.

Historical groundwater levels were retrieved from the U.S. Geological Survey National Water Information System database, from the South Carolina Department of Natural Resources WellTab database, and from South Carolina Department of Health and Environmental Control files of domestic well records. Groundwater levels from 154 wells open to the Crouch Branch aquifer were used along with 85 groundwater levels from wells screened in the McQueen Branch aquifer. These water levels range in altitude from $69 \mathrm{ft}$ (North American Vertical Datum 1988) to $555 \mathrm{ft}$. All of 
these streamflow measurements were adjusted to reflect the estimated base flow, or groundwater discharge component of the streamflow, by using hydrograph separation methods.

The groundwater-flow model was calibrated to groundwater-level conditions and stream base-flow conditions for 1900 to 2012 by using 39 stress periods. Input parameters were included in the model calibration process including horizontal hydraulic conductivity, horizontal anisotropy, specific storage, drain conductance, and recharge. The model was calibrated with an automated parameter-estimation approach using the computer program PEST, with regularized inversion and pilot points. Calibrated hydraulic conductivity values for the Crouch Branch and McQueen Branch aquifers ranged from 2 to 112 feet per day (ft/d). Calibrated hydraulic conductivity values for the McQueen Branch confining unit ranged from $1.3 \times 10^{-5}$ to $1.0 \mathrm{ft} / \mathrm{d}$. Calibrated specific storage values were $2.6 \times 10^{-2}$ per foot for the Crouch Branch aquifer, $7.8 \times 10^{-4}$ per foot for the McQueen Branch confining unit, and $1.95 \times 10^{-4}$ per foot for the McQueen Branch aquifer. Calibrated vertical anisotropies for both aquifers and the confining unit were 3.0. Calibrated horizontal anisotropy ranged from 1.0 to 4.1 (dimensionless) in the Crouch Branch aquifer, was 3.0 in the McQueen Branch confining unit, and ranged from 1.0 to 5.2 in the McQueen Branch aquifer.

Water levels from 154 wells open to the Crouch Branch aquifer were used in the calibration process along with water levels from 85 wells open to the McQueen Branch aquifer. The target calibration criteria for the groundwater level measurements were $\pm 10 \mathrm{ft}$ of the observed value. For the Crouch Branch aquifer groundwater levels (154 total), 22 percent, or 35 out of 154 , were outside of the \pm 10 -ft calibration target with 26 measurements $+10 \mathrm{ft}$ and 9 measurements outside of $-10 \mathrm{ft}$. For the McQueen Branch aquifer groundwater levels ( 85 total), 22 percent, or 19 out of 85 , were outside of the \pm 10 -ft calibration target with 14 measurements $+10 \mathrm{ft}$ and 5 measurements outside of $-10 \mathrm{ft}$. Base-flow measurements from 44 sites were included in the calibration process. Data from five continuous streamflow gages were used in the model calibration process to provide base-flow discharges over time. The calibration process produced acceptable fits on the base flows derived from all five of these gages. Discrete streamflow measurements (converted to base flows) from 39 locations were used for model calibration. Generally, the simulated base-flow values were similar in magnitude to the observed base-flow values for these 39 locations, but the groundwater-flow model did not capture the variability present in the base-flow observations primarily due to the longer model stress periods of 2 to 5 years during the time these data were collected.

Water budgets for the overall study area, the Alligator Rural Water and Sewer Company well field near McBee, South Carolina, and the Carolina Sandhills National Wildlife Refuge acquisition area consist of the various components of the groundwater-flow system that were simulated with the groundwater-flow model. For the overall study area budget, for the 1998 and 2012 simulation periods, recharge rates vary from 56 to 1,679 million gallons per day (Mgal/d), drains (streams and rivers) vary from 653 to $1,127 \mathrm{Mgal} / \mathrm{d}$, storage-in terms range from 0 to $568 \mathrm{Mgal} / \mathrm{d}$, storage-out terms range from 0 to $556 \mathrm{Mgal} / \mathrm{d}$, total inflows through all specified-head boundaries vary from 97 to $111 \mathrm{Mgal} / \mathrm{d}$, total outflows through all specified-head boundaries vary from 68 to $86 \mathrm{Mgal} / \mathrm{d}$. Well withdrawals over the simulation time from 1900 to 2012, range from 0 to $9.3 \mathrm{Mgal} / \mathrm{d}$. For the Alligator Rural Water and Sewer Company well field area near McBee, for the wet budget year (1998), water going into storage (30.2 Mgal/d) is one of the largest budget terms, but in the dry year (2012), water coming into the Crouch Branch aquifer from storage is the largest budget term (39.9 Mgal/d). Streamflow in the wet year is $47.1 \mathrm{Mgal} / \mathrm{d}$ and is reduced to $30.9 \mathrm{Mgal} / \mathrm{d}$ in the dry year (2012). Total pumping from the well field (along with irrigation wells in the budget area) is $1.5 \mathrm{Mgal} / \mathrm{d}$ in 1998 and 4.0 Mgal/d in 2012. For the Carolina Sandhills National Wildlife Refuge acquisition area, the largest components of the wet and dry water budgets are the recharge and the streamflows. In the wet year (1998), simulated recharge was 231.9 Mgal/d with streamflows of $151.3 \mathrm{Mgal} / \mathrm{d}$; in the dry year (2012), recharge was $31.4 \mathrm{Mgal} / \mathrm{d}$, and stream base flows were $92.7 \mathrm{Mgal} / \mathrm{d}$. Storage fluxes for the wet year (1998) were $78.4 \mathrm{Mgal} / \mathrm{d}$ into storage. In 2012, the low recharge rate resulted in relatively lower groundwater levels and 65.2 Mgal/d moving out of storage. Most of the CSNWR acquisition area is underlain by only the Crouch Branch aquifer; the McQueen Branch confining unit and the McQueen Branch aquifer pinch out against the Piedmont crystalline bedrock in the southeastern part of the acquisition area.

A concern that has been expressed by the South Carolina Department of Natural Resources, local residents of the McBee area, and the Carolina Sandhills National Wildlife Refuge has been that pumping from the Alligator Rural Water and Sewer Company well field (and other wells in the area) is lowering groundwater levels and reducing stream base flows in the well field area. Water budgets have been derived from the groundwater-flow model for Cedar Creek, Lower Alligator Creek, two unnamed tributaries to the Lynches River near the U.S. Highway 1 crossing, Blackwell Creek, and the upper reaches of Beaverdam Creek. Two simulated water budgets for selected streams from 2012 are presented: (1) the budget from the original model, which includes withdrawals from the Alligator Rural Water and Sewer Company well field along with nearby irrigation and industrial supply wells and (2) a modified version of the model with all pumping removed from the model throughout the simulation period. Simulated stream base flows for 2012 for the selected streams in the ARWS well-field area for the two versions of model are similar. Removing all pumping from the model for the entire simulation period (1900-2012) produces negligible differences in base flow for the selected streams. 


\section{References}

Aucott, W.R., 1988, Predevelopment ground-water flow system and hydrologic characteristics of the Coastal Plain aquifers of South Carolina: U.S. Geological Survey WaterResources Investigations Report 86-4347, 66 p.

Aucott, W.R., 1996, Hydrology of the Southeastern Coastal Plain aquifer system in South Carolina and parts of Georgia and North Carolina: U.S. Geological Survey Professional Paper 1410-E, $83 \mathrm{p}$.

Aucott, W.R., Davis, M.E., and Speiran, G.K., 1984, Waterlevel measurements for the Coastal Plain aquifers of South Carolina prior to development: U.S. Geological Survey Open-File Report 84-803, 36 p., 1 sheet.

Aucott, W.R., Davis, M.E., and Speiran, G.K., 1987a, Geohydrologic framework of the Coastal Plain aquifers of South Carolina: U.S. Geological Survey Water-Resources Investigations Report 85-4271, 7 sheets.

Aucott, W.R., Meadows, R.S., and Patterson, G.G., 1987b, Regional ground-water discharge to large streams in the upper Coastal Plain of South Carolina and parts of North Carolina and Georgia: U.S. Geological Survey WaterResources Investigations Report 86-4332, 28 p.

Aucott, W.R., and Newcome, Roy, Jr., 1986, Selected aquifer test information for the Coastal Plain aquifers of South Carolina: U.S. Geological Survey Water-Resources Investigations Report 86-4159, 30 p.

Aucott, W.R., and Speiran, G.K., 1985a, Ground-water flow in the Coastal Plain aquifers of South Carolina: Ground Water, v. 23 , no. 6 , p. $736-745$.

Aucott, W.R., and Speiran, G.K., 1985b, Potentiometric surfaces of November 1982 and declines in the potentiometric surfaces between the period prior to development and November 1982 for the Coastal Plain aquifers of South Carolina: U.S. Geological Survey Water-Resources Investigations Report 84-4215, 7 sheets.

Aucott, W.R., and Speiran, G.K., 1985c, Potentiometric surfaces of the Coastal Plain aquifers of South Carolina prior to development: U.S. Geological Survey Water-Resources Investigations Report 84-4208, 5 sheets.

Aucott, W.R., and Speiran, G.K., 1986, Geohydrology and water quality of the Coastal Plain aquifers of South Carolina, in Proceedings of the Symposium on Ground Water and Environmental Hydrology in South Carolina, South Carolina Department of Health and Environmental Control, Columbia, S.C., 1985, p. 26-50.

Aucott, W.R., and Speiran, G.K., 1996, Hydrology of the Southeastern Coastal Plain aquifer system in South Carolina and parts of Georgia and North Carolina: U.S. Geological Survey Professional Paper 1410-E, 83 p.

Barker, Carroll, 1986, Base-flow measurements at partialrecord sites on small streams in South Carolina: U.S. Geological Survey Open-File Report 86-143, 97 p.
Bell, Henry, III, Butler, R.J., Howell, D.E., and Wheeler, W.H., 1974, Geology of the Piedmont and Coastal Plain near Pageland, South Carolina and Wadesboro, North Carolina: Carolina Geological Society, Guidebook for 1974 Annual Meeting, $16 \mathrm{p}$.

Berry, E.W., 1914, The Upper Cretaceous and Eocene floras of South Carolina and Georgia: U.S. Geological Survey Professional Paper 84, 200 p.

Bloxham, W.M., 1976, Low-flow characteristics of streams in the inner Coastal Plain of South Carolina: South Carolina Water Resources Commission Report 5, 27 p.

Bloxham, W.M., 1979, Low-flow frequency and flow duration of South Carolina streams: South Carolina Water Resources Commission Report 11, 25 p.

Butler, J.R., and Howell, D., 1977, Preliminary geologic map of Chesterfield County: Set of ten 7.5-minute quadrangles (Patrick, Cash, Angelus, Chesterfield, Lake Robinson, Mt. Croghan, Ruby, Morven West, Pageland, and Middendorf), South Carolina Department of Natural Resources, Land, Water, and Conservation Division, South Carolina Geological Survey, Open-File Report 17, 1 sheet.

Cherry, R.N., Badr, A.W., and Wachob, Andrew, 2001, General hydrology of South Carolina: South Carolina Department of Natural Resources, 5 p.

Colquhoun, D.J., Woollen, I.D., Van Nieuwenhuise, D.S., Padgett, G.G., Oldham, R.W., Boylan, D.C., Bishop, J.W., and Howell, P.D., 1983, Surface and subsurface stratigraphy, structure and aquifers of the South Carolina Coastal Plain: University of South Carolina, Department of Geology, 78 p.

Cooke, C.W., 1936, Geology of the Coastal Plain of South Carolina: U.S. Geological Survey Bulletin 867, 196 p.

de Marsily, G., Lavedan, G., Boucher, M., and Fasanino, G., 1984, Interpretation of interference tests in a well field using geostatistical techniques to fit the permeability distribution in a reservoir model, in Verly, G., and others, eds., Geostatistics for natural resources characterization, Part 2: D. Reidel Publishing Company, p. 831-849.

Di Luzio, M., Johnson, G.L., Daly, C., Eischeid, J.K., and Arnold, J.G., 2008, Constructing retrospective gridded daily precipitation and temperature datasets for the conterminous United States: Journal of Applied Meteorology and Climatology, v. 47, p. 475-497.

Doherty, J.E., 2003, Ground water model calibration using pilot points and regularization: Ground Water, v. 41, no. 2, p. $170-177$.

Doherty, J.E., 2008a, PEST, model independent parameter estimation user manual (5th ed.): Brisbane, Australia, Watermark Numerical Computing, accessed October 2, 2008, at http://pesthomepage.org/.

Doherty, J.E., 2008b, PEST, model independent parameter estimation-Addendum to user manual (5th ed.): Brisbane, Australia, Watermark Numerical Computing, accessed October 2, 2008, at http://pesthomepage.org/. 
Doherty, J.E., and Hunt, R.J., 2010, Approaches to highly parameterized inversion-A guide to using PEST for groundwater-model calibration: U.S. Geological Survey Scientific Investigations Report 2010-5169, 59 p.

Falls, W.F., 1994, Lithologic descriptions of two cores and ground-water-quality data from five counties in the northeastern part of the Coastal Plain of South Carolina, 1988 and 1991: U.S. Geological Survey Open-File Report 94-58, $45 \mathrm{p}$.

Fetter, C.W., Jr., 1988, Applied hydrogeology (2d ed.): McMillian Publishing Company, 592 p.

Fine, J.M., and Kuniansky, E.L, 2014, Simulation of groundwater flow and saltwater movement in the Onslow County area, North Carolina: Predevelopment-2010: U.S. Geological Survey Scientific Investigations Report 2013-5236, 106 p., http://dx.doi.org/10.3133/sir20135236.

Fry, J., Xian, G., Jin, S., Dewitz, J., Homer, C., Yang, L., Barnes, C., Herold, N., and Wickham, J., 2011, Completion of the 2006 National Land Cover Database for the Conterminous United States: Photogrammetric Engineering and Remote Sensing, v. 77, no. 9, p. 858-864.

Gellici, J.A., Kiuchi, M., Harwell, S.L., and Badr, A.W., 2004, Hydrologic effects of the June 1998-August 2002 drought in South Carolina: South Carolina Department of Natural Resources Water Resources Report 34, 56 p.

Gellici, J.A., and Lautier, J.C., 2010, Hydrogeologic framework of the Atlantic Coastal Plain, North and South Carolina, in Campbell, B.G., and Coes, A.L., eds., 2010, Groundwater availability in the Atlantic Coastal Plain of North and South Carolina: U.S. Geological Survey Professional Paper 1773, 241 p., 7 pls.

Halford, K.J., and Hanson, R.T., 2002, User guide for the drawdown-limited, Multi-Node Well (MNW) Package for the U.S. Geological Survey's modular three-dimensional finite-difference ground-water flow model, versions MODFLOW-96 and MODFLOW-2000: U.S. Geological Survey Open-File Report 02-293, 39 p.

Hanson, R.L., 1991, Evapotranspiration and droughts, in Paulson, R.W., Chase, E.B., Roberts, R.S., and Moody, D.W., comps., National water summary 1988-89-Hydrologic events and floods and droughts: U.S. Geological Survey Water-Supply Paper 2375, p. 99-104.

Harbaugh, A.W., Banta, E.R., Hill, M.C., and McDonald, M.G., 2000, MODFLOW-2000, the U.S. Geological Survey's modular ground-water flow model-User guide to modularization concepts and the ground-water flow process: U.S. Geological Survey Open-File Report 00-92, 121 p.

Harrelson, L.G., and Fine, J.M., 2006, Selected well data used in determining ground-water availability in the North and South Carolina Atlantic Coastal Plain aquifer systems: U.S. Geological Survey Open-File Report 2006-1298, 81 p.

Healy, R.W., Winter, T.C., LaBaugh, J.W., and Franke, O.L., 2007, Water budgets - Foundations for effective waterresources and environmental management: U.S. Geological Survey Circular 1308, 90 p.
Hockensmith, B.L., 2003, Potentiometric surface of the Middendorf aquifer in South Carolina-November 2001: South Carolina Department of Natural Resources, Land, Water, and Conservation Division, Water Resources Report 28, 1 sheet.

Hockensmith, B.L., 2008, Potentiometric surface of the Middendorf aquifer in South Carolina-November 2004: South Carolina Department of Natural Resources, Land, Water, and Conservation Division, Water Resources Report 46, 11 p., 1 sheet.

Hockensmith, B.L., 2012, Potentiometric surface of the Middendorf aquifer in South Carolina-November 2009: South Carolina Department of Natural Resources, Land, Water, and ConservationDivision, Water Resources Report 51, 17 p., 1 sheet.

Homer, C., Huang, C., Yang, L., Wylie, B., and Coan, M., 2004, Development of a 2001 National Landcover Database for the United States: Photogrammetric Engineering and Remote Sensing, v. 70, no. 7, p. 829-840.

Kuniansky, E.L., and Danskin, W.R., 2003, Models gone badCommon modeling problems and how to solve them: in MODFLOW and More 2003 Understanding through modeling, Conference Proceedings edited by Poeter, Zheng, Hill, and Doherty: Colorado School of Mines, Golden, Colorado, p. 356-360.

Kuniansky, E.L., Gómez-Gómez, Fernando, and Torres-González, Sigfredo, 2004, Effects of aquifer development and changes in irrigation practices on ground-water availability in the Santa Isabel area, Puerto Rico: U.S. Geological Survey Water-Resources Investigations Report 03-4303, 56 p.

LaVenue, A.M., and Pickens, J.F., 1992, Application of a coupled adjoint sensitivity and kriging approach to calibrate a groundwater flow model: Water Resources Research, v. 28 , no. 6 , p. $1543-1569$.

Leake, S.A., 1997, Modeling groundwater flow with MODFLOW and related programs: U.S. Geological Survey Fact Sheet 121-97, 4 p.

Lu, J., Sun, G., McNulty, S.G., and Amatya, D.M., 2005, A comparison of six potential evapotranspiration methods for regional use in the southeastern United States: Journal of the American Water Resources Association, v. 41, no. 3, p. 621-633.

Mitchell, H.L., 2004, Springs of South Carolina: South Carolina Department of Natural Resources, Hydrology/Geology, Map 6, 1 sheet.

National Oceanic and Atmospheric Administration, 2012, Cheraw, S.C., precipitation data, accessed January 2014 at http://www.ncdc.noaa.gov/data-access/quick-links.

Newcome, Roy, Jr., 1993, Pumping tests of the Coastal Plain aquifers in South Carolina with a discussion of aquifer and well characteristics: South Carolina Water Resources Commission Report 174, 52 p. 
Newcome, Roy, Jr., 2000, Results of pumping test of the Coastal Plain of South Carolina: State of South Carolina Department of Natural Resources Open-File Report 5, 26 p.

Newcome, Roy, Jr., 2002, Ground-water resources of Kershaw County, South Carolina: State of South Carolina Department of Natural Resources, Land, Water and Conservation Division, Water Resources Report 24, 20 p.

Newcome, Roy, Jr., 2004a, Ground-water resources of Lee County, South Carolina: State of South Carolina Department of Natural Resources, Land, Water and Conservation Division, Water Resources Report 33, 19 p.

Newcome, Roy, Jr., 2004b, Ground-water resources of Chesterfield County, South Carolina: State of South Carolina Department of Natural Resources, Land, Water and Conservation Division, Water Resources Report 36, 16 p.

Nystrom, P.G., Willoughby, R.H., and Price, L.K., 1991, Cretaceous and Tertiary stratigraphy of the upper Coastal Plain, South Carolina, in Horton, J.W., Jr., and Zullo, V.A., Geology of the Carolinas: Carolina Geological Society fiftieth anniversary volume, p. 221-240.

Prowell, D.C., Christopher, R.A., Waters, K.E., and Nix, S.K., 2003, The chrono- and lithostratigraphic significance of the type section of the Middendorf Formation, Chesterfield County, South Carolina: Southeastern Geology, v. 42.

Rodriguez, J.A., Newcome, Roy, Jr., and Wachob, A., 1994, Ground-water resources of Darlington, Dillon, Florence, Marion, and Marlboro Counties, South Carolina, with an analysis of management alternatives for the City of Florence: State of South Carolina; Department of Natural Resources, Water Resources Division Report 1, 119 p.

Rutledge, A.T., 1998, Computer programs for describing the recession of ground-water discharge and for estimating mean ground-water recharge and discharge from streamflow records-Update: U.S. Geological Survey Water-Resources Investigations Report 98-4148, 43 p.

Sanford, W.E., and Selnick, D.L., 2012, Estimation of evapotranspiration across the conterminous United States using a regression with climate and land-cover data: Journal of the American Water Resources Association, v. 49, no. 1, p. 217-230.

Sloan, Earl, 1908, Hand book of South Carolina-Resources, institution, and industry of the State ( $2 \mathrm{~d}$ ed.): Columbia, South Carolina, The State Department of Agriculture, Commerce, and Immigration, chapter V, p. 77-145.

Sloto, R.A., and Crouse, M.Y., 1996, HYSEP-A computer program for streamflow hydrograph separation and analysis: U.S. Geological Survey Water-Resources Investigations Report 96-4040, 46 p.

Sohl, N.F., and Owens, J.P., 1991, Cretaceous stratigraphy of the Carolina Coastal Plain, in Horton, J.W., Jr., and Zullo, V.A., eds., The geology of the Carolinas-50th anniversary volume, Carolina Geological Society: Knoxville, Tenn., University of Tennessee Press, p. 191-220.
South Carolina Department of Health and Environmental Control, 2002, South Carolina water use report 1999 and 2000 summary data compilation: Bureau of Water, $24 \mathrm{p}$.

South Carolina Department of Health and Environmental Control, 2006, R.61-113, Groundwater use and reporting: South Carolina Department of Health and Environmental Control, 20 p., accessed August 2013 at http://www.scdhec. gov/environment/water/regs/r61-113.pdf.

South Carolina Department of Health and Environmental Control, 2007, South Carolina water use report 2006 annual summary: Bureau of Water, $39 \mathrm{p}$.

Thornthwaite, C.W., 1948, An approach toward a rational classification of climate: Geographical Review, v. 38, no. 1, p. 55-94.

Turnipseed, D.P., and Sauer, V.B., 2010, Discharge measurements at gaging stations: U.S. Geological Survey Techniques and Methods, book 3, chap. A8, 87 p. (Also available at $h t t p: / / p u b s . u s g s . g o v / t m / t m 3-a 8 /$.

U.S. Census Bureau, 2013, State and county quick facts, accessed March 2, 2013, at http://quickfacts.census.gov/ qfd/states/45/45025.html.

U.S. Fish and Wildlife Service, 2007, Carolina Sandhills National Wildlife Refuge, accessed July 20, 2013, at http://www.fws.gov/southeast/pubs/CarolinaSandhills Brochure.pdf .

U.S. Fish and Wildlife Service, 2009, National Wetlands Inventory: Washington, D.C., U.S. Department of the Interior, U.S. Fish and Wildlife Service, accessed January 7, 2014, at http://www.fws.gov/wetlands/.

U.S. Geological Survey, 1999, National Elevation Dataset: U.S. Geological Survey Fact Sheet 148-99, 3 p.

U.S. Geological Survey, 2007, Facing tomorrow's challengesU.S. Geological Survey science in the decade 2007-2017: U.S. Geological Survey Circular 1309, 67 p.

U.S. Geological Survey, 2010, National Hydrography Dataset, accessed March 1, 2010, at http://nhd.usgs.gov/index.html.

Wachob, A., Park, D.A., and Newcome, R., Jr., eds., 2009, South Carolina State water assessment (2d ed.): South Carolina Department of Natural Resources, Land, Water, and Conservation Division [variously paged].

Wait, R.L., and Davis, M.E., 1986, Configuration and hydrology of the pre-Cretaceous rocks underlying the southeastern Coastal Plain aquifer system: U.S. Geological Survey Water-Resources Investigations Report 86-4010, $1 \mathrm{pl}$.

Zalants, M.G., 1991, Low-flow characteristics of natural streams in the Blue Ridge, Piedmont, and upper Coastal Plain Physiographic Provinces of South Carolina: U.S. Geological Survey Water-Resources Investigations Report 90-4188, 92 p., 1 sheet. 


\title{
Appendix 1. Bedrock Topography of the McBee, South Carolina, Area, Based on Bedrock Altitudes From Geologic Borings and Analysis of Ambient Seismic Noise by the Horizontal-to-Vertical Spectral-Ratio Method
}

\author{
By Bruce G. Campbell and Emily B. Voytek
}

The bedrock surface underlying the McBee, South Carolina (S.C.), area (fig. 1-1) defines the lower boundary of a groundwater-flow model presented earlier in this report. This model is used to simulate groundwater flow in the Atlantic Coastal Plain aquifers and confining unit underlying the area. This bedrock surface is represented by a no-flow boundary in the model, and the topography of the bedrock surface plays a role in determining the patterns of groundwater flow. Mapping the altitude of the bedrock surface will provide a guide for the drilling of wells in the McBee area in the future. The bedrock surface in the McBee area has not been characterized in this detail in the past; however, several geologic borings have been drilled to bedrock and are either public supply or test wells (table 1-1).

The McBee area (fig. 1-1) bedrock surface was mapped by using the horizontal-to-vertical spectral-ratio (HVSR) method, which is a passive seismic technique that uses an analysis of the horizontal and vertical components of ambient seismic noise or microtremors (Lane and others, 2008). The HVSR method has been developed as a method to collect data on the depth to bedrock in a manner that is noninvasive and less expensive than drilling. These advantages are beneficial in an area such as McBee, where the depths to bedrock commonly exceed 300 feet (ft). The U.S. Geological Survey (USGS) used the HVSR method during 2011-12 to estimate bedrock depth in areas for which there was little information from drilling and to prepare a map of the altitude of the bedrock surface for the McBee area.

The HVSR method has been used in several areas of the northeastern United States to map buried bedrock surfaces underlying glacial sediments in areas in Ohio, Connecticut, and Massachusetts. Haefner and others (2010) mapped sediment thickness in Franklin County, Ohio. Fairchild and others (2013) produced a map of the bedrock surface underlying the western Cape Cod, Massachusetts, area. Brown and others (2013) mapped the bedrock surface along several transects in the Woodbury, Connecticut, area.

The area of the bedrock topographic map presented in this report is in western Kershaw and eastern Chesterfield Counties and underlies the towns of Bethune and McBee,

Table 1-1. Locations and altitudes of bedrock surfaces for geologic borings where bedrock was encountered during drilling in the McBee, South Carolina, area.

[See figure 1-1 for well locations; NAD 83, North American Datum of 1983; NAVD 88, North American Vertical Datum of 1988]

\begin{tabular}{|c|c|c|c|c|}
\hline \multirow{2}{*}{$\begin{array}{c}\text { Well } \\
\text { identification }\end{array}$} & Latitude & Longitude & \multirow{2}{*}{$\begin{array}{c}\text { Altitude of } \\
\text { bedrock surface, } \\
\text { in feet (NAVD 88) }\end{array}$} & \multirow{2}{*}{$\begin{array}{l}\text { Used to } \\
\text { calculate local } \\
\text { regression line }\end{array}$} \\
\hline & (Decimal degree & enced to NAD 83) & & \\
\hline CTF-288 & 34.4745917 & -80.2221556 & 121 & Yes \\
\hline CTF-88 & 34.4466695 & -80.2176500 & -34 & Yes \\
\hline CTF-107 & 34.4361472 & -80.2945444 & 25 & Yes \\
\hline CTF-313 & 34.4168175 & -80.3003830 & -45 & Yes \\
\hline CTF-106 & 34.4907500 & -80.2475000 & 125 & Yes \\
\hline CTF-60 & 34.5123749 & -80.2475694 & 40 & No \\
\hline CTF-219 & 34.4636111 & -80.2319444 & 56 & Yes \\
\hline KER-66 & 34.4162649 & -80.3292383 & 40 & No \\
\hline KER-23 & 34.4318205 & -80.3345160 & 38 & No \\
\hline
\end{tabular}




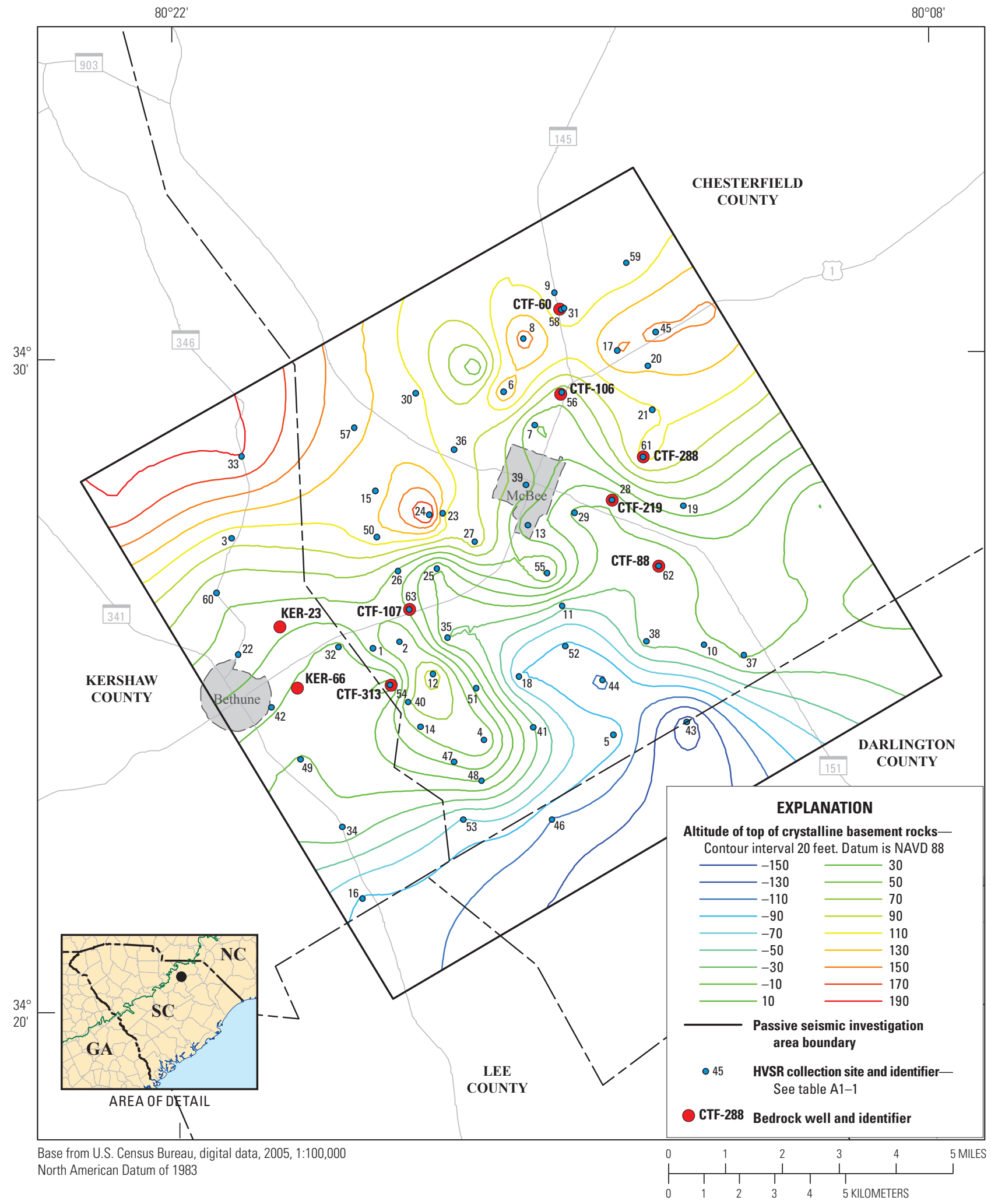

Figure 1-1. Altitude of the top of the crystalline basement rocks underlying the Atlantic Coastal Plain in the McBee, South Carolina, area as interpreted from horizontal-to-vertical spectral-ratio (HVSR) measurements and geologic borings. 
S.C. (fig. 1-1). The study area is underlain by unconsolidated Atlantic Coastal Plain sediments that primarily consist of medium- to coarse-grained sand and clay, which in turn overlie an unknown type of crystalline bedrock that is part of the Piedmont Province.

There are two Atlantic Coastal Plain aquifers underlying the area: the Crouch Branch aquifer which is underlain by the McQueen Branch confining unit, which is underlain by the McQueen Branch aquifer. The water table is in the unconfined Crouch Branch aquifer, but most of the public supply wells are screened in the both the Crouch Branch and McQueen Branch aquifers. In the McBee area, these aquifers are used for public supply and for domestic, agricultural, and commercial needs, and 2-3 million gallons per day of high-quality potable water are typically withdrawn. The Alligator Rural Water and Sewer Company operates 11 production wells within the area. These wells supply potable water to the immediate area surrounding the well field along with a much wider area that encompasses most of Chesterfield County through a network of pipelines.

The HVSR method is based on a relation between the resonance frequency of ambient seismic noise as measured at land surface and the thickness of the unconsolidated sediments that overlie consolidated bedrock. A spectral analysis of the ambient seismic noise from the earth's surface is used to determine the fundamental resonance frequency for the measurement site. Ambient seismic noise is composed of microtremors caused by ocean waves, wind, rainfall, and anthropogenic activities such as traffic and industry (Ibs-von Seht and Wohlenberg, 1999). The HVSR method works best at locations where the subsurface can be approximated by a two-layer model consisting of a layer of generally homogeneous, unconsolidated sediments overlying a consolidated bedrock layer. The HVSR method is effective in areas where there is a strong contrast in acoustic impedance between the sediment and bedrock (Nakamura, 1989; Lane and others, 2008). The McBee area's geologic structure, with unconsolidated Atlantic Coastal Plain sediments on top of crystalline bedrock, produces a distinct contrast in acoustic impedance at the sediment-bedrock interface. However, in most cases, some thickness of highly weathered crystalline rock or saprolite are expected at the bedrock-Atlantic Coastal Plain geologic contact that could range in thickness from zero to possibly tens of feet thick. How this saprolite layer will affect the acoustic impedance between the Atlantic Coastal Plain and the crystalline bedrock is unknown.

At each measurement site, a single, broadband, threecomponent seismometer was used to record ambient seismic noise from the earth's surface. The seismometer was placed directly on the ground or on a metal plate with spikes. The spikes on the bottom of the seismometer or the metal plate were firmly driven into the ground to ensure that the seismometer was securely coupled with the earth. A bull's eye spirit level and north arrow built into the instrument along with an external compass were used to level the instrument and align it with magnetic north. Data were collected for 30 minutes at each location. To minimize noise, the equipment was set up away from traffic when possible and where pedestrians, including those collecting the data, were not walking in the immediate area around the equipment; these disturbances create excessive noise that later would have had to be removed from the record.

In areas that have a strong acoustic impedance contrast between the bedrock and overlying sediments, such as near $\mathrm{McBee}$, the seismic noise induces resonance at frequencies in the range of about 0.1 to 100 hertz. The ratio of the average horizontal- and vertical-component amplitude spectrums produces a spectral ratio curve with peaks at fundamental and higher order resonance frequencies. Resonance frequencies are a function of sediment layer thickness and average layer shear-wave velocity (Lane and others, 2008).

Measurements were made at 64 locations in and around McBee (fig. 1-1) by using the field methods described in Lane and others (2008). Additional measurements were collected at several surrounding bedrock wells where the altitude of the bedrock surface is known. These were used to calculate a local regression line based on the relation between the sediment thickness $(z)$ and the resonance frequency ( $f r$, in hertz) of the main peak in $\mathrm{H} / \mathrm{V}$ spectra:

$$
z=a f r-b,
$$

where

$a$ and $b \quad$ are empirically derived coefficients (Ibs-von Seht and Wohlenberg, 1999).

Once calculated, the local regression line was used to determine sediment thickness from observed frequencies within the same geologic framework. The values for $a$ (205.78) and $b$ (1.611) were determined from the observed resonance frequencies and corresponding depths to bedrock (table 1-1; fig. 1-2) at six well locations around the McBee area. Using these values for $a$ and $b$, the depth of the bedrock $(y$, in feet) is calculated to be

$$
y=205.78 f r-1.611 .
$$

Once the depths to bedrock were calculated by using the local regression, bedrock altitude was determined by subtracting the depths determined from a $2-\mathrm{ft}$ contour light detection and ranging (lidar) digital elevation model (South Carolina Department of Natural Resources, 2013). These bedrock altitudes were used to draw bedrock altitude contours (fig. 1-1).

The bedrock surface mapped by using the HVSR technique generally dips from the higher altitude areas in the northwest to lower altitude areas in the southeast as would be expected from previous maps of the bedrock surface (Wait and Davis, 1986; Gellici and Lautier, 2010) (fig. 1-1; table 1-1). However, there is a high area just south of U.S. Highway 1 in the southern part of the study area. Observed bedrock altitudes range from $234 \mathrm{ft}$ above the North American Vertical Datum of 1988 (NAVD 88) to $169 \mathrm{ft}$ below NAVD 88. Atlantic Coastal Plain sediment thicknesses in the study area range from a low of $73 \mathrm{ft}$ to a high of $510 \mathrm{ft}$ with a mean of $321 \mathrm{ft}$ (fig. 1-2; table 1-2). 
Table 1-2. Horizontal-to-vertical spectral-ratio measurement locations, estimated bedrock altitude, landsurface altitude, and estimated sediment thickness of the Atlantic Coastal Plain sediments in the vicinity of McBee, South Carolina.

[NAD 83, North American Datum of 1983; NAVD 88, North American Vertical Datum of 1988]

\begin{tabular}{|c|c|c|c|c|c|}
\hline \multirow{2}{*}{$\begin{array}{l}\text { Location on } \\
\text { figure 1-1 }\end{array}$} & Latitude & Longitude) & Bedrock altitude & $\begin{array}{c}\text { Land-surface } \\
\text { altitude }\end{array}$ & \multirow{2}{*}{$\begin{array}{c}\text { Thickness } \\
\text { (in feet) }\end{array}$} \\
\hline & \multicolumn{2}{|c|}{ (Decimal degrees referenced to NAD 83) } & \multicolumn{2}{|c|}{ (In feet NAVD 88) } & \\
\hline 1 & 37.849411 & 84.648333 & 43 & 316 & 273 \\
\hline 2 & 37.856279 & 84.646610 & 79 & 322 & 243 \\
\hline 3 & 37.814447 & 84.611561 & 95 & 273 & 178 \\
\hline 4 & 37.876814 & 84.679160 & 76 & 307 & 231 \\
\hline 5 & 37.909740 & 84.678888 & -75 & 365 & 440 \\
\hline 6 & 37.884929 & 84.567685 & 163 & 485 & 322 \\
\hline 7 & 37.892470 & 84.578798 & 21 & 461 & 440 \\
\hline 8 & 37.890339 & 84.550941 & 171 & 528 & 357 \\
\hline 9 & 37.898729 & 84.536380 & 104 & 523 & 419 \\
\hline 10 & 37.933598 & 84.651085 & -14 & 325 & 339 \\
\hline 11 & 37.897945 & 84.637029 & -52 & 399 & 451 \\
\hline 12 & 37.864432 & 84.657269 & 115 & 369 & 254 \\
\hline 13 & 37.889858 & 84.610733 & 5 & 462 & 457 \\
\hline 14 & 37.860841 & 84.674222 & 54 & 295 & 241 \\
\hline 15 & 37.851419 & 84.597980 & 112 & 263 & 151 \\
\hline 16 & 37.844580 & 84.728412 & -95 & 266 & 361 \\
\hline 17 & 37.914162 & 84.555639 & 157 & 479 & 322 \\
\hline 18 & 37.886312 & 84.659133 & -96 & 361 & 457 \\
\hline 19 & 37.929537 & 84.606325 & 43 & 429 & 386 \\
\hline 20 & 37.921798 & 84.561014 & 131 & 425 & 294 \\
\hline 21 & 37.922475 & 84.575124 & 106 & 291 & 185 \\
\hline 22 & 37.815128 & 84.648954 & 45 & 280 & 235 \\
\hline 23 & 37.868406 & 84.605855 & 95 & 383 & 288 \\
\hline 24 & 37.864897 & 84.606217 & 221 & 364 & 143 \\
\hline 25 & 37.866354 & 84.623620 & -24 & 371 & 395 \\
\hline 26 & 37.856480 & 84.623985 & 43 & 340 & 297 \\
\hline 27 & 37.876261 & 84.615529 & 110 & 404 & 294 \\
\hline 28 & 37.911463 & 84.603593 & -9 & 410 & 419 \\
\hline 29 & 37.901833 & 84.607226 & -17 & 440 & 457 \\
\hline 30 & 37.862530 & 84.567231 & 119 & 447 & 328 \\
\hline 31 & 37.900256 & 84.541972 & 88 & 528 & 440 \\
\hline 32 & 37.840660 & 84.647664 & 2 & 212 & 210 \\
\hline
\end{tabular}


Table 1-2. Horizontal-to-vertical spectral-ratio measurement locations, estimated bedrock altitude, landsurface altitude, and estimated sediment thickness of the Atlantic Coastal Plain sediments in the vicinity of McBee, South Carolina.-Continued

[NAD 83, North American Datum of 1983; NAVD 88, North American Vertical Datum of 1988]

\begin{tabular}{|c|c|c|c|c|c|}
\hline \multirow{2}{*}{$\begin{array}{l}\text { Location on } \\
\text { figure 1-1 }\end{array}$} & Latitude & Longitude) & Bedrock altitude & $\begin{array}{l}\text { Land-surface } \\
\text { altitude }\end{array}$ & \multirow{2}{*}{$\begin{array}{c}\text { Thickness } \\
\text { (in feet) }\end{array}$} \\
\hline & \multicolumn{2}{|c|}{ (Decimal degrees referenced to NAD 83) } & \multicolumn{2}{|c|}{ (In feet NAVD 88) } & \\
\hline 33 & 37.817788 & 84.585477 & 193 & 266 & 73 \\
\hline 34 & 37.839979 & 84.705309 & -13 & 253 & 266 \\
\hline 35 & 37.868460 & 84.645883 & -39 & 395 & 434 \\
\hline 36 & 37.871742 & 84.585569 & 95 & 293 & 198 \\
\hline 37 & 37.943626 & 84.654813 & -3 & 373 & 376 \\
\hline 38 & 37.918914 & 84.649299 & -16 & 318 & 334 \\
\hline 39 & 37.889756 & 84.597815 & 66 & 469 & 403 \\
\hline 40 & 37.857870 & 84.666138 & 74 & 340 & 266 \\
\hline 41 & 37.889385 & 84.675554 & -27 & 355 & 382 \\
\hline 42 & 37.823108 & 84.666270 & 13 & 275 & 262 \\
\hline 43 & 37.928500 & 84.675685 & -169 & 320 & 489 \\
\hline 44 & 37.907508 & 84.661280 & -119 & 391 & 510 \\
\hline 45 & 37.923970 & 84.550210 & 155 & 413 & 258 \\
\hline 46 & 37.893446 & 84.705457 & -114 & 282 & 396 \\
\hline 47 & 37.869031 & 84.685790 & 33 & 284 & 251 \\
\hline 48 & 37.875807 & 84.692154 & 14 & 347 & 333 \\
\hline 49 & 37.829974 & 84.683146 & -12 & 269 & 281 \\
\hline 50 & 37.851431 & 84.612769 & 125 & 330 & 205 \\
\hline 51 & 37.875357 & 84.662330 & 23 & 268 & 245 \\
\hline 52 & 37.898266 & 84.649970 & -96 & 393 & 489 \\
\hline 53 & 37.870852 & 84.704310 & -77 & 241 & 318 \\
\hline 54 & 37.853421 & 84.660496 & -32 & 296 & 328 \\
\hline 55 & 37.894385 & 84.626260 & 88 & 416 & 328 \\
\hline 56 & 37.899640 & 84.568398 & 53 & 473 & 420 \\
\hline 57 & 37.846643 & 84.577455 & 132 & 308 & 176 \\
\hline 58 & 37.901042 & 84.541566 & 234 & 524 & 290 \\
\hline 59 & 37.917224 & 84.527710 & 89 & 432 & 343 \\
\hline 60 & 37.810147 & 84.628921 & 52 & 294 & 242 \\
\hline 61 & 37.919778 & 84.590056 & 124 & 458 & 334 \\
\hline 62 & 37.922735 & 84.625304 & -34 & 389 & 423 \\
\hline 63 & 37.858967 & 84.636295 & 27 & 297 & 270 \\
\hline
\end{tabular}




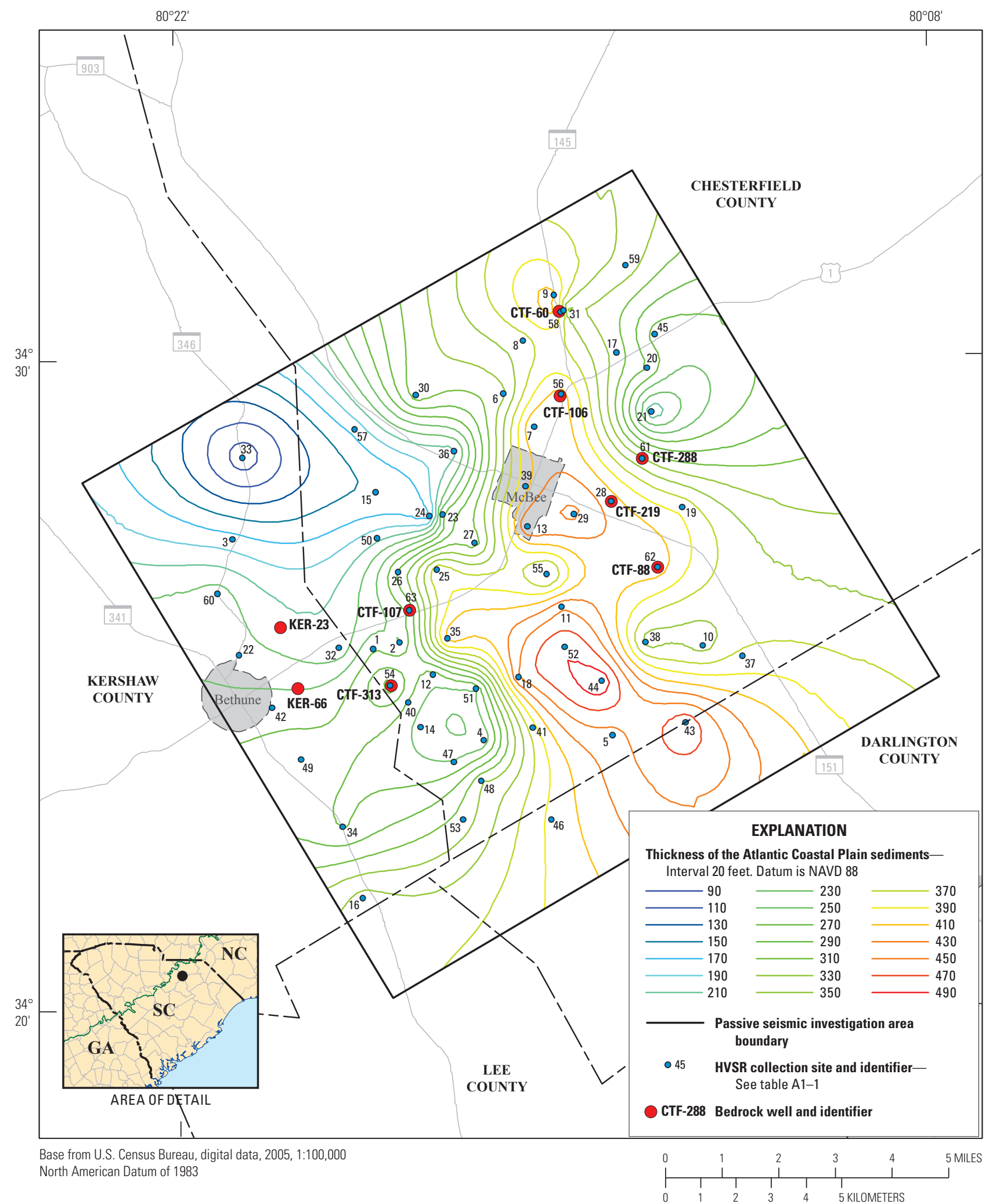

Figure 1-2. Thickness of the Atlantic Coastal Plain sediments in the McBee, South Carolina, area as interpreted from horizontal-to-vertical spectral-ratio (HVSR) measurements and geologic borings. 


\section{References}

Brown, C.J., Voytek, E.B., Lane, J.W., Jr., and Stone, J.R., 2013, Mapping bedrock surface contours using the horizontal-to-vertical spectral ratio (HVSR) method near the middle quarter area, Woodbury, Connecticut: U.S. Geological Survey Open-File Report 2013-1028, 4 p., available at http://pubs.usgs.gov/of/2013/1028/.

Fairchild, G.M., Lane, J.W., Jr., Voytek, E.B., and LeBlanc, D.R., 2013, Bedrock topography of western Cape Cod, Massachusetts, based on bedrock altitudes from geologic borings and analysis of ambient seismic noise by the horizontalto-vertical spectral-ratio method: U.S. Geological Survey Scientific Investigations Map 3233, 1 sheet, maps variously scaled, 17-p. pamphlet, on one CD-ROM. (Also available at http://pubs.usgs.gov/sim/3233/.)

Gellici, J.A., and Lautier, J.C., 2010, Hydrogeologic framework of the Atlantic Coastal Plain, North and South Carolina, in Campbell, B.G., and Coes, A.L., eds., 2010, Groundwater availability in the Atlantic Coastal Plain of North and South Carolina: U.S. Geological Survey Professional Paper 1773, 241 p., 7 pls.

Haefner, R.J., Sheets, R.A., and Andrews, R.E., 2010, Evaluation of the horizontal-to-vertical spectral ratio (HVSR) seismic method to determine sediment thickness in the vicinity of the South Well Field, Franklin County, Ohio: The Ohio Journal of Science, v. 110, no. 4, p. 77-85.
Ibs-von Seht, Malte, and Wohlenberg, Jürgen, 1999, Microtremor measurements used to map thickness of soft sediments: Bulletin of the Seismological Society of America, v. 89 , no. 1 , p. 250-259.

Lane, J.W., Jr., White, E.A., Steele, G.V., and Cannia, J.C., 2008, Estimation of bedrock depth using the horizontal-tovertical (H/V) ambient-noise seismic method, in Symposium on the Application of Geophysics to Engineering and Environmental Problems, April 6-10, 2008, Philadelphia, Penn., Proceedings: Denver, Colo., Environmental and Engineering Geophysical Society, 13 p.

Nakamura, Y., 1989, A method for dynamic characteristics estimation of subsurface using microtremor on the ground surface: Quarterly Report of the Railway Technical Research Institute, v. 30, no. 1, p. 25-30.

South Carolina Department of Natural Resources, 2013, South Carolina Laser Imaging Detection and Ranging Data: South Carolina Geographic Information System Data, accessed April 30, 2013, at http://www.gis.sc.gov/projects_lidar.html.

Wait, R.L., and Davis, M.E., 1986, Configuration and hydrology of the Pre-Cretaceous rocks underlying the southeastern Coastal Plain aquifer system: U.S. Geological Survey Water-Resources Investigations Report 86-4010, 1 pl. 


\section{Appendix 2. Water Well Data Used for Model Calibration of the Crouch Branch and McQueen Branch Aquifers}

Data for all wells used in model calibration of the Crouch Branch and McQueen Branch aquifers for water years 1949 through 2012 are presented in tables 2-1 and 2-2. These data will be available for download as Excel spreadsheets on this publication's Web page at http://pubs.usgs.gov/sir/2014/5050/. 
Manuscript approved March 21, 2014

Prepared by the USGS Science Publishing Network Publishing Service Centers

Edited by Kimberly A. Waltenbaugh, Raleigh Illustrations by Denis Sun, West Trenton Layout by Caryl J. Wipperfurth, Raleigh

For more information concerning this report, contact: Director, South Carolina Water Science Center U.S. Geological Survey 720 Gracern Road

Stephenson Center, Suite 129

Columbia, SC 29210

http://sc.water.usgs.gov 
